Pontificia Universidade Catolica

Ana Lúcia da Silva Resende

\title{
AS ODISSEIAS DE HOMERO E DE KAZANTZÁKIS O Exílio em dois poemas
}

Tese de Doutorado

Tese apresentada como requisito parcial para obtenção do grau de Doutor em Literatura, Cultura e Contemporaneidade, no Departamento de Letras da PUC-Rio.

Orientadora: Profa. Dra. Marília Rothier Cardoso 


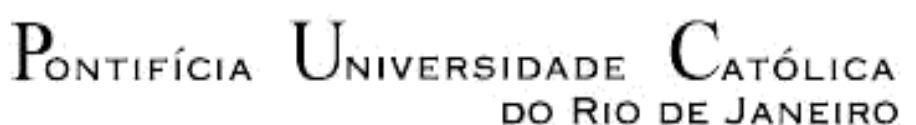

Ana Lúcia da Silva Resende

\section{AS ODISSEIAS DE HOMERO E DE KAZANTZÁKIS \\ O Exílio em dois poemas}

Tese apresentada como requisito parcial para obtenção do grau de Doutor em Literatura, Cultura e Contemporaneidade, no Departamento de Letras da PUC-Rio. Aprovada pela Banca Examinadora abaixo assinada

Profa. Marilia Rothier Cardoso

Orientadora

Departamento de Letras - PUC-Rio

Profa. Miriam Sutter Medeiros

Coorientadora

Departamento de Letras - PUC-Rio

Prof. Paulo Fernando Henriques Britto Departamento de Letras - PUC-Rio

Profa. Helena Franco Martins Departamento de Letras - PUC-Rio

Profa. Carlinda Fragale Pate Nuñez

UERJ

Profa. Dulcileide Virginio do Nascimento Braga

UERJ

Rio de Janeiro, 08 de fevereiro de 2020 
Todos os direitos reservados. É proibida a reprodução total ou parcial do trabalho sem autorização da universidade, do autor e do orientador.

\section{Ana Lúcia da Silva Resende}

Graduou-se em Letras pela Universidade Federal de São João Del Rei -MG UFSJ em 2003, concluiu o mestrado em Teoria Literária e Crítica da Cultura área de Concentração Literatura e Memória Cultural com bolsa CAPES em 2007 na Universidade Federal de São João Del Rei-MG UFSJ. Foi bolsita de doutorado na Pontifícia Universidade Católica (PUC -Rio) com bolsa CAPES/PROSUC/TAXAS. Doutorou-se em 2019, com a presente tese, orientada por Marília Rothier Cardoso.

Ficha Catalográfica

Resende, Ana Lúcia da Silva

As Odisseias de Homero e de Kazantzákis: o exílio em dois poemas / Ana Lúcia da Silva Resende ; orientadora: Marilia Rothier Cardoso ; coorientadora: Miriam Sutter Medeiros. - 2021. 142 f. : il. color. ; $30 \mathrm{~cm}$

Tese (doutorado)-Pontifícia Universidade Católica do Rio de Janeiro, Departamento de Letras, 2021.

Inclui bibliografia 


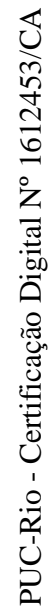

Para Paulo. 


\section{Agradecimentos}

À CAPES, pois o presente trabalho foi realizado com apoio da Coordenação de Aperfeiçoamento de Pessoal de Nível Superior - Brasil (CAPES) - Código de Financiamento 001.

À equipe da secretaria do Departamento de Letras, por toda a ajuda e atenção desde o início desta jornada. Em especial ao secretário do PPGLCC, Rodrigo Santana, profundo conhecedor dos meandros administrativos e sempre disposto a socorrer as demandas.

Minha mais sincera admiração às pessoas das professoras Helena Franco Martins coordenadora e Marília Rothier Cardoso - Coordenadora Adjunta do PPGLCC que incansavelmente trabalharam para que eu vencesse a rotina de percalços e prazos acadêmicos e pudesse ter a viabilização da defesa desta Tese garantida.

À Marília como orientadora atenta e presente. Fazendo sempre leituras criteriosas do texto, intervindo cirurgicamente e inserindo sugestões que tornaram o fluxo de compreensão mais fluído. Fazendo reiteradas revisões com o preciosismo e esmero que lhe são peculiares. Com sua postura sábia, elegante, discreta, ponderada, prudente de boa mineira que é, soube exercer com maestria e brilhantismo seu papel! Ave!

A todos os membros da banca que se dispuseram a ler o trabalho a tecer comentários, acrescentar sugestões, mostrar outros possíveis pontos de vista e agregar valor ao contribuir com possíveis mudanças de rota ou desvios de percurso a fim de tornar o tema da pesquisa mais didático e acessível a futuros leitores. A saber: Orientadora: Marília Rothier Cardoso, Co-orientadora: Miriam Sutter Medeiros; Membros da PUC Rio: Helena Franco Martins e Paulo Henriques Brito; Membros externos: Carlinda Fragale Pate Nuñez e Dulcileide Virginio do Nascimento Braga, ambas da UERJ e as suplentes Flavia Vieira Santos da PUC Rio e Fernanda Lemos de Lima da UERJ. 
O trajeto de escrita desta Tese envolve muitos deslocamentos pela busca de um objetivo.

Escrita entre 2016 e 2020 abarca mudanças de cidade, de tema e uma pandemia mundial que nos ensinou novas formas de comunicação e de rotina acadêmica. Inclusive, a defesa não será presencial e sim pela modalidade remota, testando nossa capacidade de adaptação e de atualização.

Ao refazer mentalmente a cronologia (foram dois anos) das viagens semanais entre São João Del Rei- MG e o Rio de Janeiro para estar na PUC e assistir as aulas foi possível mensurar o quanto me desloquei geograficamente nas idas e vindas para cursar os créditos as disciplinas, apresentar os trabalhos, estar na biblioteca e principalmente ter a oportunidade de conviver com os professores do PPGLCC Programa de Pós-Graduação em Literatura Cultura e Contemporaneidade da PUC Rio.

Faz-se mister registrar minha reverência a Professora Carlinda Fragale Pate Nuñez a quem tive o prazer de conhecer e me tornar aluna em 2013 na UERJ, a ela devo todo o meu deleite acadêmico pois lá cheguei cheia de ideias e conceitos esparsos, embaralhados em uma mente ávida por viabilizar um projeto de Doutorado. Sem a sua prestimosa e sempre sábia presença eu não teria conseguido percorrer todo o tortuoso caminho da escrita desta Tese. Com toda a elegância e sutileza ela sempre teve a palavra certa e a referência bibliográfica adequada e pontual para nortear nosso percurso de construção desta equação acadêmica. Em suas aulas de Teoria da Literatura na UERJ me forneceu os primeiros e essenciais autores e assim continuou fazendo durante o tempo da pesquisa. Não há palavras, adjetivos suficientes para traduzirem meu sentimento de gratidão e reconhecimento. Carlinda, a você meu muito obrigada!

Aos fiéis amigos que a PUC me concedeu, levo-os para a vida! Christina Fuscaldo, Lindoberg Campos e Ana Luiza Firmeza. Valeu pelas discussões, pela parceria e pelo incentivo! 
E finalmente ao Paulo, que veio de Portugal e entrou neste "barco" em uma escala num "porto" chamado Belo Horizonte, onde por acaso não tem mar, no decurso desta viagem e foi determinante no encontro da rota, na certeza de um caminho seguro e sem tormentas. Atuou como bússola desde o primeiro instante. Traçou caminhos em minha vida e desenhou percursos para que eu pudesse navegar num oceano de calmaria e finalizar este trabalho com serenidade, em águas calmas, com rumo certo e propósito. Me deu a mão, lançando sempre seu olhar estimulador que dizia “Eu estou aqui! Conte comigo!". Esteve ao meu lado em todas as madrugadas insones de leitura e escrita, sempre fiel e solidário. Foi também um experiente interlocutor e conselheiro nas questões acadêmicas que tanto permearam o período final de escrita. Ouviu, leu, sugeriu e tenazmente formatou o trabalho. Sem seu amor e toda a confiança que você introjetou em mim, meu bem, eu não teria conseguido! Obrigada por ter atravessado o Atlântico em busca de um desafio profissional, e nossas rotas terem maravilhosamente se encontrado! Te amo! A você minha mais profunda admiração, meu carinho e minha lealdade! 


\section{Resumo}

Resende, Ana Lúcia da Silva; Cardoso, Marília Rothier (Orientadora). As “Odisseias" de Homero e de Kazantzákis - O exílio em dois poemas. Rio de Janeiro, 2021. 144 p. de Doutorado - Departamento de Letras, Pontifícia Universidade Católica do Rio de Janeiro.

\section{As “Odisseias" de Homero e de Kazantzákis - O exílio em dois poemas} abordam o tema do exílio a partir de Ulisses, um mesmo protagonista que encarna personagens dramaticamente diferentes. As duas obras escritas em épocas muito distintas, propõem mais divergências do que convergências entre as duas narrativas gregas, mas encarnam a temática capaz de manter esse personagem principal e a problemática do exílio relevante através dos tempos. A pesquisa opera uma análise da trajetória do heroico personagem Ulisses na Odisseia do lendário Homero (ca. século VIII a. C.) e na Odisseia moderna do Prêmio Nobel grego Nikos Kazantzákis (1883-1957). A tese se compõe de três capítulos. O primeiro capítulo ocupa-se dos cantos iniciais do poema homérico (cantos IV-XII), com vistas a levantar as etapas do nóstos (retorno) do herói - percurso que descreve mais do que uma série de aventuras fabulosas: desenha-se aqui um trajeto que infunde no protagonista o sentimento do exílio e algumas de suas modalizações; os demais cantos consolidam a percepção de Ulisses perante a reintegração ao seu ambiente de origem. O segundo capítulo aborda o poema de Kazantzákis a partir das divergências em relação ao "modelo": o autoexílio e as inusitadas opções do herói moderno que se impõem à narrativa e à leitura. O terceiro capítulo contém uma antologia da poesia moderna e contemporânea (dos séculos XIX-XX) em que um seleto glossário do exílio, presentes nos episódios dos épicos gregos lidos em seus contrastes, é ilustrado. Através desta personagem, que vivenciou de forma superlativa a questão exílica em seu périplo, inseminou-se definitivamente a temática do exílio na literatura. O volume de versos e episódios envolvidos na análise indicou o método comparativo e uma peculiar intertextualidade, exercida a partir da divergência em relação ao poema homérico, como os critérios da abordagem dos textos (SHAW: 1973, p. 90), articulados menos entre si do que em função do tema do exílio. Questões poéticas e políticas denotam o exílio como ferramenta crítica e de reflexão sobre a contemporaneidade, levando-nos a pensar e repensar tópicos como 
pertencimento, fronteiras, nacionalidade e origem, ainda que a partir de um dos temas mais remotos da literatura.

\section{Palavras-chave}

Exílio; pertencimento; odisseia; literatura; narrativa; percurso. 


\section{Abstract}

Resende, Ana Lúcia da Silva; Cardoso, Marília Rothier (Orientadora). Homer's and Kazantzákis' Odysseys - Exile in two poems. Rio de Janeiro, 2021. 144 p. Tese de Doutorado - Departamento de Letras, Pontifícia Universidade Católica do Rio de Janeiro.

Homer's and Kazantzákis' Odysseys - Exile in two poems addresses the theme of exile from Ulysses' perspective, one and only, one protagonist who embodies dramatically different characters. The two works written at very diverse times, propose more divergences than convergences between the two Greek narratives, but they embody one thematic capable of maintaining this main character and the problem of relevant exile through the ages. The current research operates an analysis of the trajectory of the heroic character Ulysses in the Odyssey of the legendary Homer (ca. 8th century BC) and in the modern Odyssey of the Greek Nobel Prize Nikos Kazantzákis (1883-1957). The thesis has three chapters. In the first chapter, the Homeric poem deals with the set of initial songs of the epic (songs IV-XII), aiming to depict the stages of the hero's nóstos (return) - a route that describes more than a series of fabulous adventures: a path is drawn here that instills in the protagonist the feeling of exile and some of its modalities; the other chants consolidate Ulysses' perception regarding his reintegration towards his original belonging. The second chapter deals with Kazantzákis' poem based on divergences in relation to the "model": self-exile and the unusual options of the modern hero that impose themselves on both the narrative and the reading. The third chapter contains an anthology of modern and contemporary poetry (from the 19th-20th centuries) in which a select glossary of exile, present in the episodes of Greek epics analyzed and interpreted in their contrasts, is illustrated. Through this character, who experienced the exile perils in a superlative way in his journey, the theme of exile in literature was definitively pollinated. The volume of verses and episodes involved in the analysis guided the researcher towards the comparative method and the intertextual reading as the main criterion for approaching the texts (SHAW: 1973, p. 90), articulated according to the theme of exile. Poetic and political issues in a vast production of literary works, in the theater, in the cinema as well as in the plastic arts denote exile as a critical and reflective tool about 
contemporary times, leading us in this thesis to think and rethink topics such as belonging, borders, nationality, and origin.

\section{Keywords}

Exile; Belonging; Odyssey; Literature; Narrative; Journey. 


\section{Sumário}

$\begin{array}{ll}\text { 1. Introdução } & 11\end{array}$

2. O périplo de Ulisses: percurso Homérico 19

3. A Odisseia Moderna de Kazantzákis 54

4. O exílio como tema literário 71

4.1. Pequena e seleta antologia poética do exílio 72

4.2. Gonçalves Dias: Um "retratista" do exilado brasileiro
em Portugal

4.3. Alfred Tennyson: o antinóstos 75

4.4. O Ulisses exilado pelo prisma dos poetas Gregos 76

5. Nota final 91

6. Referências bibliográficas 92

$\begin{array}{ll}\text { 7. Anexos } & 96\end{array}$ 


\section{Introdução}

O presente estudo trata do tema do exílio de Ulisses, o célebre viajante da mais fabulosa aventura da literatura mundial, em duas obras gregas, escritas em épocas distintas, mas que confirmam o vigor e a relevância de seu personagem principal através dos tempos. Aqui se analisa a trajetória do heroico protagonista Ulisses na Odisseia de Homero (séc. VIII a.C.) e na Odisseia moderna de Nikos Kazantzákis (1883-1957), obras correlatas e díspares, que servem como suporte para a investigação das múltiplas facetas e dores contidas no drama exílico encarnado nesta emblemática e permanente figura literária.

As primeiras décadas do século XX foram lembradas por uma busca pela inovação e experimentação, em resposta à profusão de ideias e descobertas científicas iniciadas ainda no século XIX. Datam dos anos 1920 produções literárias como Ulisses (1922) de James Joyce, A terra estéril ${ }^{1}$ (1922) de T. S. Eliot, A Montanha mágica (1924) de Thomas Mann, O Processo (1925) de Franz Kafka, Mrs. Dalloway (1925) de Virginia Woolf, obras que têm em comum uma grande ambição literária, trazendo à tona ainda, ao mesmo tempo, a inquietação advinda com o fim da Primeira Guerra Mundial (1914-18). O aniquilamento da sociedade e a inquietação dos costumes provocou intensa modificação nos valores. É neste contexto social e político que Nikos Kazantzákis escreve a sua Odisseia Moderna (1938).

Kazantzákis nasceu em Megálo Kastro (hoje Heraclião), capital da ilha de Creta, em 18 de fevereiro de 1883, então uma possessão do Império Otomano. Em 1902, muda-se para Atenas, onde mais tarde cursa Direito na Universidade de Atenas. Torna-se socialista militante. Em 1907, viaja para a França com o intuito de estudar filosofia em Paris. Lá se identifica com os ensinamentos de Henri Bergson. Tinha uma persona muito inquieta frente à vida, frente à política. Sua dissertação, defendida em 1909, intitula-se "Friedrich Nietzsche sobre a filosofia do Direito e do Estado". Ao regressar à Grécia, começa a traduzir obras de filosofia.

\footnotetext{
${ }^{1}$ O poema, traduzido por Paulo Mendes Campos em 1956 pela civilização Brasileira, teve como título Terra inútil. Ivan Junqueiro, em 1922, nomeou-o Terra desolada (cf. ELIOT, T. S. Obra completa, v. 1 - Poesia. Tradução, introdução e notas de Ivan Junqueira. São Paulo: Arx, 2004). Foi A Terra Gasta para Idelma Ribeiro de Lima (cf. Poemas 1910-1930. São Paulo) e Ivo Barroso chamou-o A Terra Devastada, no Suplemento Prosa e Verso, d'O Globo, 19/09/2009, para apresentar a nova tradução da primeira seção do poema, "The Burial of the Dead".
} 
Foi Ministro de Estado em seu país (1945), tendo ocupado importantes funções na UNESCO, antes de se dedicar inteiramente à literatura. Viaja durante anos pelos lugares onde floresce a cultura greco cristã. Sua busca por autenticidade e verdade o levou a atravessar o mundo, percorrendo terrenos perigosos. Ia de país em país, de doutrina em doutrina, abraçando causas que tocavam seu coração. Morreu em 1957 de leucemia na Alemanha. Por ter sido excomungado, seu sepultamento não foi autorizado no Cemitério de Heraclião. Na década de 50, foi indicado ao Nobel por Thomas Mann e Albert Schweitzer e perdeu-o, por um voto, para Albert Camus. Ganhou, porém, o Prêmio Internacional da Paz, em 1956. Nikos Kazantzákis é considerado um dos maiores escritores do século XX. Seu texto é considerado por muitos críticos como híbrido, ou seja, formado pelo encontro dos discursos filosófico, literário e religioso. Dito isto, natural ser reconhecido como um representante da literatura mundial.

Se, à primeira vista, a associação que se faz da Odisseia de Kazantzákis com a obra homônima de Homero é automática, o cotejo das duas obras demonstra, desde o início, o abismo que há entre elas (enredos, personagens, ausência de narrativa cronológica, propósito do personagem principal, cenários, valores). Ainda que seja herdeira da longa tradição literária e filosófica constituída a partir do texto clássico de que nasce, a Odisseia moderna (1956) se diferencia, e muito, da primeira Odisseia. Na obra kazantzakiana, o autor incorpora dramas modernos: a falta de esperança, a falência das instituições e o anseio de sentido, pois Ulisses volta a navegar, quando constata que Ítaca já não há em sua mente.

Mesmo considerando visões de mundo tão diferentes e contextos históricos de produção das obras separados por larga distância temporal, ainda assim são muitos os procedimentos e efeitos afins que podem ser detectados tanto na Odisseia de Homero e na Odisseia de Nikos Kazantzákis, no tocante à construção da trajetória exílica de Ulisses.

O objetivo do presente estudo é destacar a presença seminal do exílio nas duas obras escolhidas, apontar as possibilidades de percepção deste sentimento pelo viés das afinidades e das diferenças entre estes dois autores. Como elucida o pesquisador da Literatura Mundial (World Literature), docente da Universidade de Hong Kong e de Harvard, Zhang Longxi, o reconhecimento e a divulgação de obras canônicas nacionais que permanecem pouco lidas e periféricas, tendo em vista, fundamentalmente, a língua original (não-inglesa e/ou geralmente não-europeia) 
em que foram produzidas, é uma urgência, num mundo cada vez mais globalizado e interconectado. As convergências (commonalities) entre obras são o ponto de partida para comparações frutíferas, mas o que afirma a autonomia artística de obras correlatas e lhes assegura uma metodologia eficiente é abordá-las por suas diferenças ${ }^{2}$ :

A ênfase nas diferenças preserva a apreciação da diversidade cultural, o imaginário individual e a invenção artística, polo em que a obra de referência se renova e se reposiciona, no painel mundial; a obra inseminada também se potencializa e se firma, graças à sua peculiaridade. Nas palavras ainda de Longxi,

(...) de fato apreciamos diversidade e diferença nas artes e em literatura, e naqueles estudos onde a finalidade é definir ou distinguir um objeto de outros, ênfase na diferença ou na distinção específica se torna a preocupação legítima. "Determinação é negação", como o postula Spinoza ${ }^{3}$ (LONGXI, 2011, p. 20).

No jogo com e a despeito da obra referência, o novo se dá a perceber na repetição diferida. Por outro lado, Longxi chama a atenção para o fato de que a singularidade literária é ela própria relativa": "nenhuma obra de literatura é tão única que negue a si própria a possibilidade de comparação com outras" (LONGXI: id, ib.). Merecem ser consideradas, ao mesmo tempo, portanto, as características peculiares e a visão de mundo em que cada obra está inscrita, e sua universalidade, capaz de uni-las sem apagar as diferenças. Daí a importância de avaliar a produção literária que o tema do exílio e o poema homérico fomentaram.

A aproximação inicial das obras aqui focalizadas se dá através do título homônimo e da longa tradição literária e filosófica constituída a partir do horizonte clássico onde a Odisseia homérica se localiza. É com essa visão clássica, seu imaginário, seus valores, suas crenças que a obra moderna vai contrastar. Por outro lado, o filão temático das viagens e aventuras de Ulisses se confunde com a genealogia das obras literárias que se vergaram para compreender o páthos do homem em situação de exílio.

\footnotetext{
2 "Difference or Affinity? A Methodological Issue in Comparative Studies". In Revue de littérature comparée (n`337). 2011/1. Pp. 18-24.

${ }^{3}$ No original: “(...) we indeed appreciate diversity and difference in arts and literature, and in those studies where the purpose is to define or distinguish an object from otlher objects, emphasis on difference or the specific distinctiveness becomes the legitimate concern. "Determination is negation", as Spinoza puts it."

${ }^{4}$ No original: "uniqueness is only relative and not absolute, for no work of literature is so different as to deny itself the possibility of comparison with other works".
} 
O paralelismo se estabelece também pela semelhança da constituição da obra moderna: trata-se, como o poema de Homero, de uma epopeia dividida em 24 cantos; o personagem central e herói recebe o nome de Ulisses; Ítaca é pano de fundo para o primeiro e o segundo cantos. Ulisses parece dar continuidade às ações registradas por Homero, já que o poema moderno se inicia após a matança dos Pretendentes (retomando o canto XXIII, no verso 477 da obra fundadora). A partir daí, o enredo de Kazantsákis toma outro rumo, conhece outra geografia; vários personagens do mundo clássico, mas também de épocas futuras e de fora da Grécia, ressurgem e se relacionam com Ulisses, em diálogo com os feitos de um outrora que passa se remeter a paisagens e personagens mais recentes.

O roteiro do protagonista moderno é de tal forma diverso, estranho, distante do percorrido pelo guerreiro-navegante-embusteiro de que se origina, o Ulisses homérico. Um herói, dois exílios igualmente discrepantes: ambos in medias res, porém o do Ulisses, de Homero, descrevendo o périplo de retorno ao oikos ("casa") de Laertes e ao calor de Penélope; o do Ulisses Kazantzakiano, a anábase - ao contrário da catábase (ainda que simbólica) , o descenso em direção ao Polo Sul para o maior afastamento possível da ensolarada Grécia, em direção ao polo Sul e ao desejo do autoexílio.

Pela vastidão das obras escolhidas, o critério adotado como organizador do trabalho se embasa nos textos seminais das duas obras e no recorte do exílio: na saga de Ulisses pela figura do antigo arcaico; e do outro, pós-clássico, moderno e profeticamente contemporâneo.

Ainda que a epopeia de Homero seja efetivamente o ponto de partida para a criação de uma nova Odisseia, é preciso considerar o movimento contrário como igualmente importante: epopeia construída na modernidade, a Odisseia de Kazantzákis faz parte do amplo discurso da viagem e do herói que se originou com Homero, mas dele se distanciou e a ele se opôs em diversos aspectos.

A epopeia moderna é, deste modo, não uma herdeira passiva, reprodutora da tradição homérica, com pontos de contato aqui ou ali, mas um produto do diálogo permanente com a textualidade da viagem e do herói, temas já sedimentados como eixos temáticos e simbólicos da Literatura.

Reforço o fato de a Odisseia de Homero se impor como parâmetro comparativo não apenas por ser um referencial clássico e pela presença de seu personagem principal: o mítico Ulisses. É justamente pelas diferentes focalizações 
de valores, ideias, concepções de vida formuladas por Homero e Kazantzákis que se pode depreender a amplitude do mito com que a tese lida, sua afirmatividade e suas contradições, o lógico e o incoerente da alma humana. Por que Ulisses? Por este personagem ser considerado um arquétipo capaz de perpassar toda a história e a Literatura como uma constante que nunca cessa de ser citada e retomada, mostrando capacidade de adaptação e de poder sempre ser atualizado, como na obra de Joyce. Aqui a Odisseia de Homero vai ser um elemento para se pensar a questão do exílio e do retorno do personagem a Ítaca: a obra de Kazantzákis vai mostrar a incapacidade deste de se acomodar e sua insatisfação com a volta ao lar, partindo novamente em mais uma viagem sem rumo determinado. (Anexo 1)

O ponto de interseção das duas obras é o canto XXII, verso 477, da Odisseia de Homero, quando Ulisses acabara de exterminar os Pretendentes de Penélope. A retomada dos feitos do herói lendário, entretanto, reorienta o sentido do destino glorioso do herói clássico. Logo em seu primeiro encontro com a esposa, o filho e o velho pai Laertes, longe de sentir-se apaziguado pelo fim das atribulações vividas no trajeto de retorno ao lar, o Ulisses kazantzakiano sente um profundo desencanto, e sua ilha tão desejada torna-se a seus olhos estreita e asfixiante. Ele empreende então uma nova jornada. Modificado que foi por todos os acontecimentos de seu percurso, já não se contenta com aquilo que o motivou a perseguir seu objetivo; foram tantas as vicissitudes e os desafios, que o retorno já se mostra vazio de significados. Reafirmam-se aqui as ideias de inconstância e insatisfação tão peculiares à Modernidade.

O Ulises de Kazantzákis é demasiado complexo - uma criatura da modernidade. Nele se agitam todos os problemas do homem diante da verdade e de outras questões como: discurso, propósito, percurso etc. Este apenas encontra um novo rumo ao se lançar ao mar outra vez. Navegar, em Kazantzákis, pode ser lido como a aventura do indivíduo contemporâneo para encontrar um polo ao qual se dirigir, um farol para o orientar e dar sentido à própria vida. A navegação é a metáfora do movimento sem "chão", levado pelas correntes, ventos, regido pelas estrelas e pelo horizonte; de assumir a partida sem destino, por causa da insatisfação com o que se vive e se lançar à busca do novo como superação dos valores tradicionais que levam ao conformismo.

A jornada kazantzakiana é, antes de qualquer coisa, uma travessia interior entre o Mistério abissal da origem e o Mistério do fim da vida: "Viemos de um 
abismo de trevas; findamos num abismo de trevas: ao intervalo de luz entre um $e$ outro damos o nome de vida" (KAZANTZÁKIS; 1997, p. 35-38). Nesse intervalo de luz que é a vida, há duas forças antagônicas: a que nos faz nascer a cada instante e a que nos faz morrer a cada instante. A poesia e a mística têm a missão de criar uma síntese da fragmentação da vida, marcada por duas forças antagônicas: "cumpre-nos, então, ascender a uma visão que articule e humanize estes dois prodigiosos impulsos sem princípio nem fim, e por ela regular o nosso pensamento e a nossa ação" (Kazantzákis, 1997, p. 35-38).

$\mathrm{Na}$ odisseia kazantzakiana, o herói é um peregrino dos mares. Sua navegação, entretanto, é uma transubstanciação: navegar é transubstanciar a própria vida, é purificar-se através do esquecimento de quem ele é. Em Kazantzákis, a busca não é linear. Mas acontecimentos sempre provocam exercícios interiores para retomar a jornada. Assim, quando Penélope passa a ser uma tentação que conduz ao esquecimento da natureza de Ulisses de ser eternamente navegador, acomodando-o a Ítaca, que somente outrora lhe fora importante, ele se dirige aos mares. A ilha passara a ser um ícone saudosista do passado, das ilusões e do desejo, que morrera. Ele encara a sua contradição e se põe em marcha em busca de um sentido. Ao deixar Ítaca, dirige-se ao Egito, navega pelo Nilo e tenta ordenar sua desordem. Prepara-se para enfrentar a solidão e a angústia, bem como a tentação do retorno, voltar a Ítaca. Em outros termos, o herói se imputa, elege, assume um autoexílio - uma punição para gregos e não-gregos; uma tortura para quem quer que seja; uma opção absurda, tramada pelo impasse entre a ficção antiga e a contemporânea, no ponto crucial do direito inalienável do homem ao arbítrio sobre seu destino.

A intenção deste estudo é a de consignar um registro de como é farta a literatura do exílio e de mostrar a pertinência e atualidade do tema. $\mathrm{O}$ exílio priva aquele que se encontra longe de casa de sensações, gostos, cheiros, paisagens, relações sociais e familiares, hábitos e... da língua materna. Aos que partem resta a lembrança, a saudade, o constante desejo de voltar, que é o que mantém o exilado vivo e com um propósito. Para muitas culturas, o indivíduo deve permanecer onde nasceu, fiel a sua terra, seus costumes e tradições. Longe desta, muitos perecem. Passam a sofrer do mal de exílio, um mal difícil de ser descrito, pois engloba e envolve sentimentos e sensações físicas, políticas e tocantes à esfera do Direito. Percebido em exilados, banidos, desterrados, degredados, proscritos, deportados, o 
chamado mal de exílio foi a matéria prima utilizada ao longo da história humana para a geração de obras magistrais da literatura que registraram o padecimento desta abominação e de condições sócio políticas excruciantes em páginas de relatos de viagem, romances, biografias, poemas que ficam para a posteridade como fontes de consulta e estudo na tentativa de entendimento do tema que permeia a história da humanidade.

Por que a escolha do estudo do exílio como tema de pesquisa? Desde o início do registro da história da civilização humana, os povos sofrem deslocamentos geográficos por motivações políticas e ou religiosas.

O interesse pelo tema, até a Modernidade, só cresceu.

Esta tese se organiza em três capítulos escritos sob a forma de ensaios independentes. A forma ensaística concede uma liberdade de focalizações e desobriga o formato da tese monumental para duas obras monumentais; admite o pulsar de questões aparentemente isoladas, que formarão um peculiar organismo no conjunto de que participam. Entre os ensaios autônomos, a articulação de ideias aglutina as partes, ensina a contiguidade entre elas. No primeiro capítulo encontrase a descrição do périplo de Ulisses em seu percurso homérico, relatando o difícil retorno, as etapas da travessia, os percalços por ele enfrentados, a angústia do afastamento, a geografia do desterro e grande parte dos infortúnios suportados por nosso herói.

No segundo, é focalizado o Ulisses de Kazantzákis, o protagonista que se desvia do modelo homérico. Apresenta-se aí a perspectiva de construção de um herói completamente diferente de seu antecessor. Entra em cena o herói moderno, de acordo com o contexto histórico, social e as circunstâncias em que está inscrito. Na Odisseia moderna, não há o que lembrar: os feitos do protagonista não são a inscrição do passado, mas eventos do instante, presentes, fundados a partir do término dos feitos de seu antecessor.

O herói abandona o mundo familiar, que seria o local mais presumivelmente adequado para descansar e governar após anos de luta e viagem, e se lança às paisagens do mundo real, desertos, rios, altiplanos, vales, florestas, savanas... até alcançar mares e o oceano. Nesse mosaico ambíguo, de valores problemáticos, onde se defronta com a própria necessidade de crescimento e superação. Os valores insurgem como obstáculos e a superação destes fundamenta o crescimento do herói. 
Por fim, no terceiro e último capítulo, será tratado o exílio como tema literário. Contemplará/apresentará uma seleção de poemas que se notabilizaram pela temática do exílio, são páginas que ecoam a ontologia do exílio/desterro. Páginas ontológicas que mergulham na problemática da perda de identidade, da renúncia aos direitos civis, ao abandono da identidade cultural, o martírio do isolamento. Ao transitar por estas, emerge uma visão caleidoscópica dos muitos Ulisses do passado e antecipatória dos do futuro. A intenção deste capítulo é dimensionar a atualidade, a densidade e relevância do mais antigo tema da literatura universal.

A partir daqui, inicia-se a viagem da leitura pelo tema do exílio, conduzido por duas honrosas embarcações. Dois gregos são seus timoneiros: Homero tem a bússola; Kazantzákis, a ousadia de reprogramar o destino de Ulisses. A grande metáfora de leitura é mesmo náutica, entre mares, navios, águas bravias, rotas, rumos e uma jornada em busca de conhecer-se a si mesmo.

O volume de versos e episódios envolvidos na análise indicou o método comparativo e a leitura intertextual como a principal critério de abordagem dos textos (SHAW: 1973, p. 90), articulados em função do tema do exílio. Desta forma desde a introdução fica claro o viés a respeito da metodologia, que será o comparativismo à luz do que a recepção dos clássicos vem estipulando, conforme o que Longxi e Shaw postulam.

"The critic's and scholar's task with borrowings is to discover the relationships of the use of the material in the new work to that of the old - the artistic use to which the borrowing is put". (SHAW: 1973, p. 90). 


\section{2}

\section{O périplo de Ulisses: percurso Homérico}

Apresento como início do primeiro capítulo da tese um resumo comentado da Odisseia de Homero, que retrata, sob a minha perspectiva, o "nóstos" ("retorno") de Ulisses a Ítaca e seu longo e angustiante período de afastamento do lar, da família, da pólis, do pertencimento tão caro ao homem grego (mesmo em tempos pré-helênicos). A diversidade de conceitos e sutilezas, no âmbito semântico da palavra "exílio", permite reconhecer que Ulisses foi exposto durante os dezenove anos de distanciamento do lar à ideia basicamente expressa por este conceito em quase todas as línguas: "expulsão, exclusão e afastamento". Em todas as suas manifestações e nuances, nosso herói viveu agruras no mar, longe de casa, desprovido de seu lar, de sua terra, de sua família e de seu pertencimento. Após o término da Guerra de Troia, onde ele se encontrava em serviço militar, esteve longe de casa, sim, mas ainda não exatamente em exílio; houve situações, ao longo do retorno para Ítaca, em que foi recebido por reis, princesas, ninfas e deuses, com atenções e sinais de apreço. Ainda assim, o filho de Laertes padecia a solidão, pensava na esposa à sua espera, sempre movido pela vontade de voltar ao lar.

Os poemas homéricos remontam a uma época intitulada proto-história (séculos XIII ou XII a. c.) da Grécia, período que antecedeu a destruição da civilização creto-micênica, atribuída à invasão dórica. Na tradição mítica, recebeu o aposto de "vingança dos Heráclidas", descendentes de Héracles. Os aqueus ${ }^{5}$ vindos da Europa central, ancestrais dos micênicos falantes de língua indoeuropeia, migraram para a Ásia Menor e para o sul da península Itálica. Este evento é também chamado de $1^{\text {a }}$ diáspora grega. A voz de Homero nos chega da Ásia Menor, mais exatamente da Jônia, ex-colônia micênica, celeiro da futura civilização ocidental. Nasce aí a Odisseia, uma composição oral e que foi transmitida oralmente até o século VI a.c., quando Pisístrato, tirano de Atenas, ordenou que fosse registrada por escrito.

A Odisseia é um poema épico, uma composição poética que narra a história de um povo, valorizando os seus feitos. Os textos deste gênero literário eram criados com o intuito de serem recitados e transmitidos através da oralidade, conquistando a atenção e despertando a emoção dos ouvintes.

\footnotetext{
${ }^{5}$ Aquiles, "o melhor dos aqueus", seria a representação máxima desta ancestralidade.
} 
Através dos versos da Odisseia encontramos a descrição minuciosa do périplo tortuoso do Ulisses homérico, as etapas da travessia das franjas da Ásia Menor até quase o Atlântico, os percalços por ele enfrentados, a angústia do afastamento, a geografia do desterro, com vistas à interpretação dos infortúnios suportados pelo herói e, para nós, já com o olhar problematizado pela fortuna crítica ligada à maior herdeira da Grécia, a "cultura ocidental", a uma topicalização da ontologia do exílio.

Ao nos debruçarmos sobre esta valiosa obra, vamos tomando conhecimento do campo semântico do exílio que permeia diversas passagens e episódios através de nuances e evocações. Não é para menos. Tudo é múltiplo no exílio, adquirindo proporções descomunais pela razão de o exilado estar desterrado, longe de sua origem geográfica, o único lugar onde, para quem de lá é oriundo e está distante, se encontra a ordem. Longe do seu lugar de origem, ele está exilado de si mesmo, da família, dos amigos, de sua língua, em parcial ou total isolamento. Desta forma podemos investigar, em cada nuance do exílio, facetas de caráter político, poético, sociológico, antropológico, filosófico..., uma prospecção vertiginosa. A escolha feita para ilustrar fartamente todo esse vasto "território" de exemplos é o personagem Ulisses.

Maria José de Queiroz, em sua obra intitulada Os males da ausência ou a literatura do exílio (1998), traça um inventário dos males da ausência que será muito útil para compor a problemática exílica a que Ulisses foi exposto por tanto tempo. As reações, o comportamento, as privações em terra alheia, a maneira de ser do exilado, a nostalgia de sua terra natal, compõem um conjunto que é denominado por ela como "o mal do exílio".

O estudo da Odisseia, ao descrever episódios ocorridos nas viagens e nas aventuras do personagem, permite ilustrar as várias formas como um viajante pode ser recebido - como hóspede ou hostilizado - em terras estrangeiras. Mantendo um diálogo com outras modalidades artísticas, os 24 cantos que "narram" o retorno de Ulisses após a Guerra de Troia garantiram a permanência da obra no bojo do cânone literário ocidental, sendo uma das histórias mais condensadas, adaptadas e inspiradoras para outros suportes, tais como o cinema, a televisão, além, é claro, da literatura. Citamos aqui alguns títulos de produções cinematográficas apenas a título de ilustração, pois seria objeto para uma outra abordagem que nos desviaria de nosso propósito. Merecem registro: Sommersby, o regresso de um estranho 
(França/E.U.A., Jon Amiel: 1993), ambientado na era da reconstrução americana pós-Guerra Civil, narra a história de um fazendeiro cuja esposa, quando ele volta para casa depois da guerra, suspeita de que seja um impostor e não consegue se acomodar em sua casa, nem em sua vida anterior à jornada que percorreu, pois foi modificado por tudo o que viu e vivenciou e acaba por se transformar em um estranho aos olhos de sua família. Outro título famoso, Paris, Texas (França/Alemanha, Wim Wenders: 1984), do gênero drama, conta a história de Travis, um homem que, depois de estar desaparecido por mais de quatro anos, é reencontrado pelo irmão Walt num hospital na região desértica do Texas, próximo à fronteira com o México. Maltrapilho e amnésico, é levado por Walt para a sua casa em Los Angeles, onde reencontra Hunter, seu filho de sete anos que foi abandonado pela mãe, Jane. Inicialmente estranhos, Travis e Hunter iniciam uma reaproximação que culmina numa grande amizade e no desejo secreto de reencontrar Jane e reconstruir sua verdadeira família. Ambos os filmes ilustram situações semelhantes à de Ulisses, passíveis de se repetirem em outros contextos temporais e planetários.

Voltando ao cenário da epopeia antiga e à longeva tradição homérica, deparamo-nos com monumentos em versos. Os múltiplos episódios cantam homens que, devido às proezas que realizam em seus esforços pela conquista de um objetivo, inspiram uma profunda admiração, não só pela coragem, como também pela determinação com que perseguem seu fim. Esses verdadeiros heróis encarnam a ambição humana de ultrapassar as barreiras opressivas de sua limitação para atingir uma vida mais plena, chegando o mais próximo possível da completude. Levados pela coragem e pelo impulso de cumprir o seu destino, recusam-se a admitir que exista qualquer intento que lhes seja impossível alcançar e, mesmo quando falham, não se entregam, são incapazes de reconhecer a derrota, recomeçam com um vigor ainda maior e estão sempre em marcha.

A viagem de Ulisses deveria originalmente ter durado alguns dias, mas levou muitos anos, cerca de dezenove, haja vista os desafios do mar impiedoso de Poseidon. Ao longo dos 24 cantos, o herói passa por um caleidoscópio de acontecimentos que o fazem se transformar enquanto homem. Sobrevive ao Ciclope Polifemo, vence a feiticeira Circe, resiste ao canto das Sereias e aos encantos da 
deusa Calipso, entrevista seres que habitam o inferno - o Hades ${ }^{6}$, relaciona-se com Reis e retorna cansado, mas muito sábio, ao seu lar após uma das batalhas mais sangrentas e avassaladoras da história da literatura. É esta transformação que nos interessa.

No que tange aos aspectos estruturais, a Odisseia é primorosamente bem construída. Composta em hexâmetros dactílicos (cerca de 11.600 versos!), o épico se inicia no meio de uma enorme, dupla polêmica (em Ítaca e no Olimpo) e faz bastante uso de flashbacks. Há várias narrativas que se entrelaçam, do canto I ao X, ao tema do retorno. Ulisses é alguém que não tem identificação com os lugares onde aporta, e é assombrado pela dor da distância de seu lar.

Em termos de organização do poema, podemos identificar três grandes eixos narrativos. O primeiro, conhecido por Telemaquia (cantos I a IV), narra as interações da deusa Atená com o jovem Telêmaco, a quem procura guiar durante a ausência do pai. Logo no começo, podemos conhecer o palácio onde Penélope resiste às investidas dos pretendentes. O segundo eixo focaliza a viagem de Ulisses (cantos IX a XII), quando o herói conta ao rei dos Feácios os obstáculos fantásticos que enfrentou até ali. O terceiro é também o mais extenso: trata da vingança de Ulisses (cantos XIII até XXIV), quando consegue regressar a Ítaca.

Como destaque, há o percurso bem estruturado dos cantos XII ao XIX, momento em que Ulisses narra os acontecimentos épicos de sua trajetória. O flashback do canto XIX foi analisado no elucidativo ensaio "A Cicatriz de Ulisses", de Erich Auerbach ${ }^{7}$, um ponto forte. Trata-se de estudo que traz uma abordagem original da questão da representação da realidade e do foco narrativo em obras emblemáticas da Literatura Ocidental, a partir de textos da tradição literária do ocidente. No trecho da Odisseia que analisa, aponta para a necessidade de preencher a narrativa com o máximo de acontecimentos, tornando-a farta de episódios e eventos; as experiências do herói são oferecidas como um legado a ser transmitido aos ouvintes.

\footnotetext{
${ }^{6}$ Ulisses não esteve propriamente no Hades, não conheceu a geografia infernal, como o fizeram Orfeu e Alceste, gregos, e Eneias, latino. O herói homérico convocou os moradores do Hades, mortos, para colher deles conselhos ( $O d$., XI, episódio da "Evocação dos Mortos").

${ }^{7}$ Seguindo a cronologia da literatura ocidental, o capítulo propõe contraposição da Odisseia de Homero em relação aa textos bíblicos como abertura do livro Mímeisis, escrito em Istambul entre maio de 1942 e abril de 1945, e publicado em Berna (Suíca), em 1946, pela A. Frarnke Co. A obra foi escrita no exílio, para escapar à perseguição nazista aos judeus.
} 
Para a imensa maioria de teóricos e estudiosos, a Odisseia é uma obra de imenso valor didático. Os filósofos socráticos consideravam Homero como educador da Grécia. Uma das principais funções que se atribui à obra é o ensinamento: exortação ao trabalho, preceitos sobre agricultura, navegação e vida moral, além de calendários, orientações sobre o clima e o tempo, orações e práticas litúrgicas, hábitos e costumes de mortais e imortais; a vida dos senhores, servos, artistas, camponeses, sacerdotes e soldados; demiurgos e profissionais; as atribuições a homens e mulheres, velhos e criados; festas populares e funerais; homens do mar, comerciantes e mendigos que permeiam os versos da obra.

O título da trajetória épica tomou a forma de substantivo e tornou-se signo de longa viagem, percurso amplo, às vezes árduo e complexo. Destacam-se como temas gerais abordados na obra o código moral sobre cuidar das pessoas, ser hospitaleiro para com o estrangeiro em viagem e a partilha do que se recebe com os demais. Na obra, um arquétipo para toda a humanidade é a chegada do herói, seu retorno ao conforto e à segurança do lar, apresentando ainda um conflito filosófico entre livre arbítrio e destino.

Elaborada ao longo de séculos de tradição oral, a Odisseia teve a sua forma fixada por escrito sob Pisístrato (séc. VI a.C.). Ao vencer inúmeros percalços durante sua jornada, Ulisses evolui, deixando as posturas impulsivas e imaturas de seu percurso inicial em favor de um comportamento sábio e ponderado. Tendo como fio condutor a inteligência, seu maior dom, e a raiz de sua singularidade, Ulisses é detentor de uma mente de "muitas cores", que lhe fornece "as qualidades" do verdadeiro artesão. O traço heroico de Ulisses está em sua métis (esperteza). Sua argúcia se manifesta no uso de sorrelfas ${ }^{8}$, blefes e discursos enganosos. Os ardis que o notabilizam podiam ser tanto físicos (como alterar sua aparência, auxiliado pelos deuses) quanto verbais. A falha de caráter mais evidente em Ulisses é sua soberba ou hýbris ${ }^{9}$.

Ao longo do tempo, a obra homérica teve sua influência referendada e continuamente citada e um dos autores que se debruçou sobre este estudo de permanência de uma obra através de seu personagem, Piero Boitani, em A sombra de Ulisses, afirma que a presença incessante do personagem se configura na sua permanente influência:

\footnotetext{
${ }^{8}$ Sorrelfa: 1. Dissimulação silenciosa para enganar ou iludir; sonsice.

${ }^{9}$ Diz-se de pessoa matreira, manhosa, dissimulada; sorrelfo.
} 
que surge silenciosamente do mito, permeando nossa cultura: o Ulisses que reencarna, com valências diferentes, na poesia e na história através dos séculos, desde Homero até nossos dias. A presença constante desta figura, o fascínio que nunca deixou de exercer sobre a imaginação, são sinais de que ela traz em si o destino de homens (BOITANI, 2005, p. 01).

Outra obra que se debruça sobre o estudo de nosso personagem objeto de estudo é The return of Ulysses, A cultural history of Homers's Odissey - na qual Edith Hall (2008) afirma que "A aventura emocionante de Ulisses é a mais citada na cultura humana e na literatura. Um dos textos mais populares de todos os tempos. Que prova ser resistente e duradouro”. Hall explica ainda o fascínio permanente do épico de Homero em termos de sua susceptibilidade extraordinária para adaptação a novos tempos e formatos.

Outro clássico, sobre a origem e a transmissão do caráter heroico de Ulisses, William Bedell Stanford, discute os aspectos do mais intrigante personagem literário em The Ulysses theme- A study in the adaptability of a traditional hero (1992). O livro fornece substância para reflexões contemporâneas sobre o heroísmo e a virtude, sem desmerecer as relações entre os homens e a intervenção dos deuses. Ao contrário, o homericista investiga a adaptabilidade do personagem título, o protótipo do herói homérico que não renuncia a um heroísmo peculiar e pujante, muito menos ao direito à ambiguidade. Um personagem mais em consonância com a figura do herói contemporâneo, não poderíamos imaginar. Na verdade, Ulisses foi contemporâneo a todas as épocas, sobrevivendo em obras primas de todos os gêneros. Talvez esta proeza se deva à condição de abandono absoluto a que ele resistiu; às provações insuportáveis a que ele venceu; à superação do maior de todos os males e à mais depreciada experiência que um grego poderia suportar - o exílio e a condição de exilado.

Passemos à análise do exílio, nos cantos da obra, e aos acontecimentos mais determinantes para a transformação do herói Ulisses ao longo de seu nóstos até Ítaca. Na visão de Maria José de Queiroz, a experiência exílica é paradigmática de nosso herói:

Numa experiência sobre-humana, à mercê da fúria de Poseidon, Ulisses figura essa forma de heroísmo. Dez anos de luta encarniçada às portas de Troia, nove anos de rotas e derrotas no mar afastaram-no de sua ilha. De porto em porto, ao capricho dos deuses, o seu exílio se converte em périplo de assombros. Conhece todos os 
horrores das águas profundas, de cuja imensidão emerge, em vagalhões, o furor do filho de Saturno. Nenhuma prova, temerária que fosse, conseguiu esmorecê-lo. (QUEIROZ, 1998, p. 43).

A temática do Canto I ao Canto IV da Odisseia, a Telemaquia, compreendendo as duas viagens empreendidas por Telêmaco em busca de notícias do pai, é a prospecção de pistas, o resgate de rastros, a busca por vestígios do itinerário de Ulisses, ao deixar Troia. Ulisses já estava há dez anos longe de casa, em missão, mas não em exílio. Foi porque precisava ir, porque fora convocado, não teve escolha. Após este longo período passa extensos nove anos da errância no caminho de volta pelo Mediterrâneo, antes de reencontrar Ítaca, ilha da qual era basiléus, Rei. Este, sim, é o período exílico do personagem.

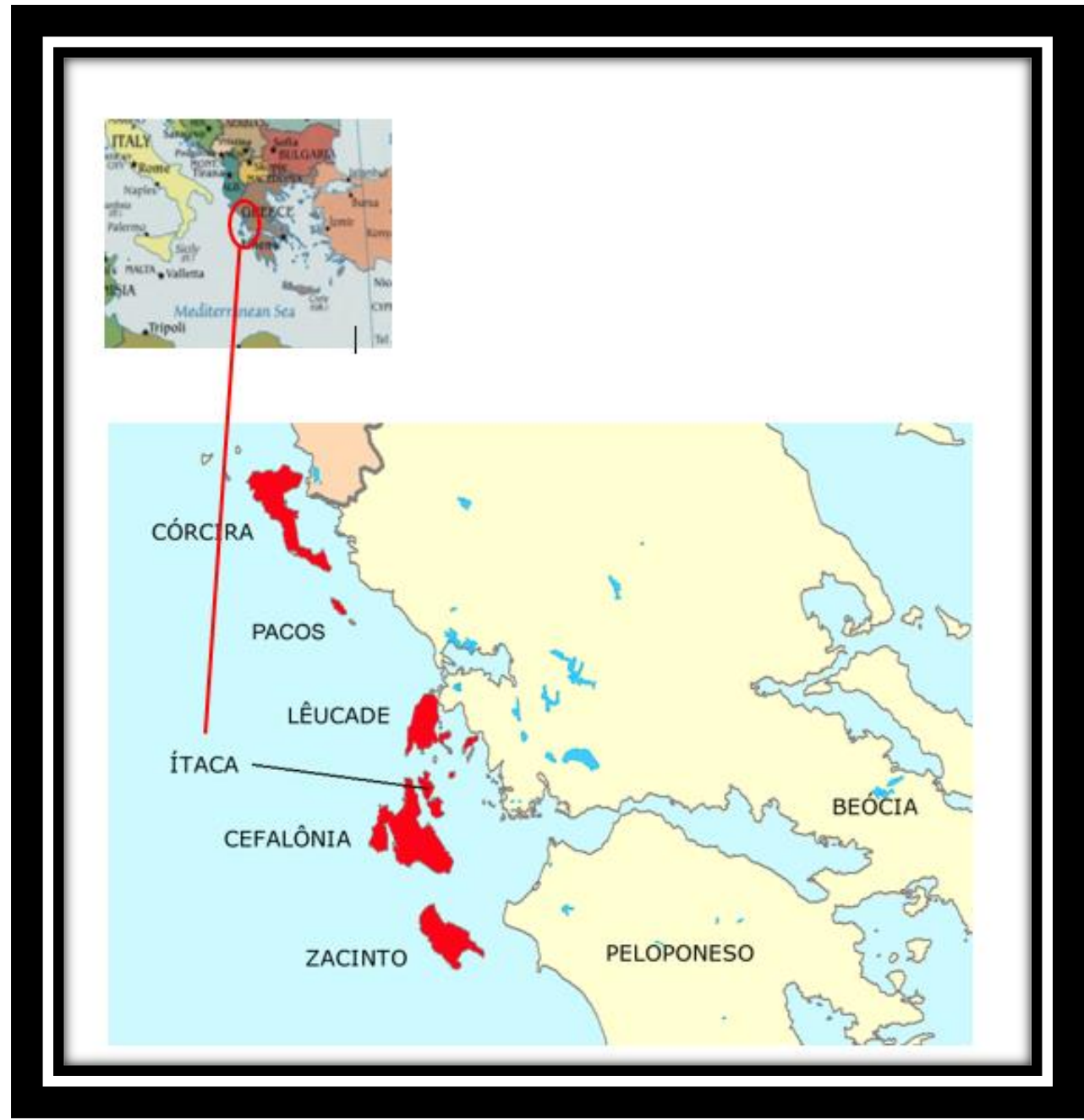

Localização de Ítaca - Reino de Ulisses

O narrador abre o poema pedindo inspiração à Musa, para contar a história de Ulisses, que vagueia tentando regressar à casa, depois da Guerra de Troia. No 
Olimpo, os deuses organizam um concílio para decidir sobre o destino do herói: Atená pede a palavra e conduz a sua defesa, alegando que ele está sendo atormentado por Poseidon, o rei dos mares. A deusa conta que o mortal é prisioneiro em Ogígea, a ilha de Calipso que insiste em conquistar o seu amor. Ele é prisioneiro do amor que ela nutre pelo viajante, é um exílio que tem uma nota sentimental. Ela o retém e o quer perpetuamente. É muito bem tratado, recebendo honras de rei e saboreando manjares e ótima bebida, mas está privado de sua liberdade. Hermes, o mensageiro dos deuses, coloca as suas sandálias douradas com asas e desce à terra a fim de interferir para que ele seja libertado. Enquanto isso, Atená resolve, disfarçada, visitar a família de Ulisses em Ítaca.

No palácio, Telêmaco está triste, vendo o espaço mais precioso para o grego -- o lar -- invadido por inúmeros pretendentes arrogantes que querem se casar com a sua mãe. A ausência de Ulisses trouxe à sua família uma série de problemas característicos da cultura e da legislação gregas, como o ilustra Maria José de Queiroz, em obra já mencionada:

Convém registrar: os bens do ausente, no Direito grego, não estavam defendidos de apropriação nem de roubo. Na ausência do chefe, a família em desamparo não podia apelar nem tinha direito a recorrer à justiça enquanto durasse a sua permanência no estrangeiro. Só o soldado a serviço do rei, tinha asseguradas suas posses. E a mulher, incluída no seu equipamento - aposkeu $\boldsymbol{e}^{10}$, gozava de proteção da lei. Atente-se, por exemplo, no caso de Penélope: se bem que mantida a salvo dos cento e oito pretendentes, tecendo à porfia, vê, aterrorizada, que lhe haviam saqueado a despensa e já se preparavam para apropriar-se de seus bens. (QUEIROZ, 1998, p. 41).

Neste cenário de tristeza e angústia surge a deusa Atená, disfarçada e travestida como um homem desconhecido, fala com o jovem e dá notícias de seu pai, anunciando que ele ainda está vivo, tentando trazer esperança e otimismo para a família.

Penélope chora com saudades do marido, cansada dos pretendentes que enganou por mais de três anos; pediu que esperassem que acabasse de tecer uma mortalha para o sogro Laertes, mas durante a noite, desfazia o tecido. Depois de descobrirem o seu estratagema, os homens exigem que tome uma decisão. $\mathrm{O}$ próprio povo pressiona Penélope a casar ou regressar para casa do pai. O que permeia e justifica a questão é uma situação de vazio de poder que se esconde numa

\footnotetext{
${ }^{10}$ Palavra grega que significa "mobiliário", "bagagem"; secundariamente, "latrina".
} 
discussão sob o pretexto de se tratar de um assunto de foro privado, o da sobrevivência econômica da casa de Ulisses. Nessa assembleia, são interlocutores: Telêmaco, em defesa da casa de seu pai, e Antínoo, pela «facção dos Pretendentes». É neste contexto que pela primeira vez se ouve falar, pela boca dos pretendentes, da mortalha que Penélope tecia para Laertes. A narrativa diz-nos, pela voz de Antínoo, parafraseando uma declaração que fizera Penélope:

Jovens, já que o divino Ulisses morreu, não apresseis as minhas bodas, até que eu termine a mortalha para o herói Laertes, - temo que se inutilizem os meus fios para o tempo em que o fatal destino da dolorosa morte o fizer sucumbir, não suceda que alguma das Aqueias por esta terra me censure de ser enterrado sem mortalha quem possuía tantos bens. Assim disse ela e o nosso intrépido coração deixou-se convencer. Então, durante o dia, trabalhava numa grande teia; desfazia-a, porém de noite, depois de ao seu lado ter acendido as tendas. Deste modo, conseguiu, durante três anos, esconder o ardil e que os Aqueus acreditassem nela (HOMERO, Odisseia, II, 95-105, 2015, p.48) ${ }^{11}$.

Neste contexto, Telêmaco parte, com uma pequena tripulação, em busca de notícias do pai; Atená também embarca na viagem, disfarçada de Mentor. Durante a jornada, a deusa motiva o jovem e o educa, ensinando-o a lidar e a dialogar com os outros. Primeiro visitam Nestor e depois seguem para Esparta. Lá, consultam-se com Menelau, o último a voltar da guerra e Helena, sua esposa. Helena, misteriosa, coloca uma droga nas bebidas para diminuir seu sofrimento e lamenta a força da paixão que motivou a batalha. Enquanto isso, em Ítaca, os pretendentes percebem que Telêmaco partiu e planejam uma cilada.

Penélope descobre o plano e reza para Atená, que entra no quarto quando ela dorme e tenta consolá-la e avisar que seu filho está sendo protegido. Hermes chega à ilha de Calipso; Ulisses está na praia, olhando o mar e chorando de saudades.

Calipso se revolta e tenta novamente convencer Ulisses a ficar oferecendolhe a imortalidade, mas ele não aceita. Ele, que foi seu prisioneiro durante sete longos anos, só sobrevive alimentando o desejo de voltar a rever sua família. Assim, Maria José de Queiroz (1998, p. 41) ilustra este episódio: "Perdidamente apaixonada, Calipso propõe-lhe o irrecusável: a juventude eterna e a imortalidade. Mas Ulisses persevera no seu propósito.” Reverente, o herói responde:

\footnotetext{
${ }^{11}$ As citações da Odisseia serão todas retiradas da mesma fonte, a tradução de Carlos Alberto Nunes, publicada em 2015, e referidas de acordo com a convenção internacional: título abreviado (Od.) seguido do número do canto (em algarismos romanos) e dos versos (em arábicos).
} 
"Deusa potente, não queiras com isso agastar-te, que eu sei/perfeitamente que a minha querida e prudente Penélope/ é de menor aparência e feições menos belas que as tuas. / Ela é uma simples mortal; tu, eterna e de eterno frescor. / Mas, apesar de tudo isso, consumo-me todos os dias / para que a pátria retorne e reveja o meu dia de volta" (Od., V, 215-220).

Dito isto, ela se vê como vencida e resignadamente a deusa fornece os materiais para que o marido de Penélope construa a jangada, na qual depois viaja por dezoito dias sem rumo. Embora Poseidon estivesse tentando matá-lo, surge Leucoteia, uma divindade aquática, que o aconselha a nadar até ao reino dos Feácios. Atena manda parar os ventos, para ajudar na jornada.

As aventuras de Ulisses começam efetivamente no canto $\mathrm{V}$, cujo tema é: como o herói escapou de Calipso? Aqui começa de fato a Odisseia. Em forma de relato que vai acontecer em retrospectiva, inicia-se pela penúltima etapa do nóstos, o retorno. A narrativa não segue a sequência cronológica dos fatos, se dá in medias res, ou seja, se inicia "no meio dos acontecimentos. Pela perspectiva do exílio, trata-se de sua forma mais suave - o retorno é dificultado pelo amor, a liberdade é retirada pelo apego ao outro. Que liberdade Ulisses tem em Ogígia? Total. Mas está longe da família, das bênçãos de Héstia, a deusa que protege a união familiar. Sua condição é de anéstios, uma das designações para o exilado, no vocabulário do exílio. Não tem escolha, está privado de seu direito mais básico: o de ir e vir livremente, já que está aprisionado por Calipso.

Ulisses segue adiante para Creta, a Ilha dos Feácios. Lá é recebido no Palácio de Knossos, sede do Império Cretense e lar do rei Alcínoo. Atená entra no palácio dos Feácios durante a noite e convence Nausícaa, a princesa, a lavar a roupa para o seu casamento no rio. Lá, Ulisses está sujo e nu, depois do naufrágio, assustando a princesa e suas aias. 


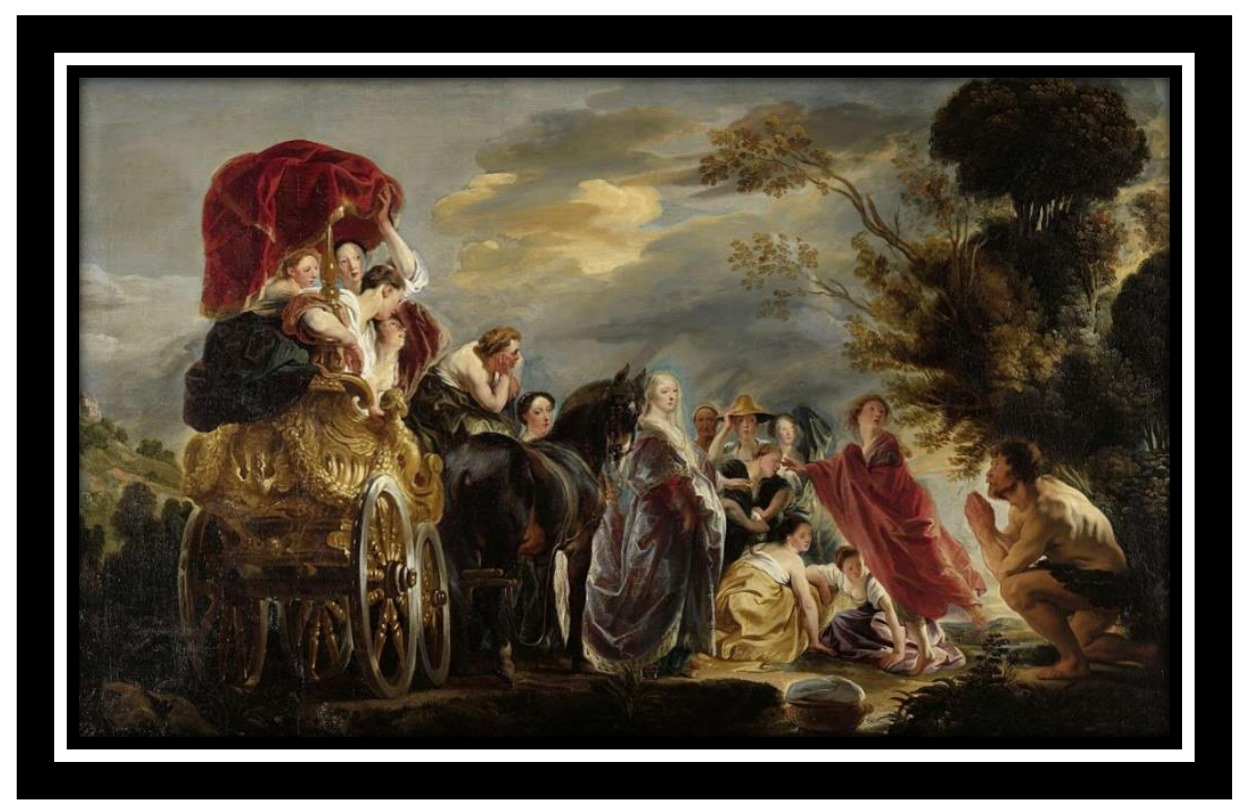

Ulisses e Nausicaa, Jacob Jordaens (1630-1635). Rijksmuseum, Amsterdam.

Resolve suplicar ajuda de longe, através de um discurso muito bem construído e elogioso. A princípio adentra o palácio de forma obscura, como um viajante desconhecido e em trânsito em terras estrangeiras, longe de sua casa, como podemos perceber na narrativa de Maria José de Queiroz (2015, p. 46): “À sua chegada ao palácio de Alcínoo, rei dos Feácios, Ulisses, incógnito, assenta-se sobre as cinzas, junto do fogo. Ao ver o forasteiro em tão humilhante posição, o herói Equeneu, o mais velho dos Feácios, exorta que o convidem à mesa":

"Ó rei Alcínoo, não julgo decente, nem belo, deixar / que um estrangeiro se sente no chão e na cinza, à lareira. / Os circunstantes aguardam somente que o exemplo lhes dês. / Vamos! Levanta o estrangeiro e o conduz a sentar-se em poltrona / cheia de ornatos de prata; em seguida, aos arautos dá ordens / para que o vinho misture, e todos libemos a Zeus, / fulminador, que acompanha em seus passos os nobres pedintes. / A despenseira repasto lhe apreste do que há no palácio" (Od., VII, 159166).

Aqui temos a ilustração expressa do código da hospitalidade reiteradamente citado por Homero ao longo da Odisseia. Ao pedinte, viajante, soldado, peregrino, estrangeiro em viagem não é recomendado negar acolhida nem agasalho. Ao serem recebidos pelo anfitrião, devem usufruir das comidas e bebidas servidas aos demais convidados. E a todos estes aconselha-se tentar aliviar e amenizar a errância do viajante com esta acolhida. 
O termo "hospitalidade", segundo Michel Foucault (1967), vem do latim hospes (hóspede), formado da mesma raiz de hostis (estranho), que também significa o inimigo estranho (hostilis) ou estrangeiro. Este, por sua vez, ora é reconhecido como hóspede (fr. hôte), ora como inimigo. Para Foucault, a hospitalidade significa o acolhimento incondicional do outro que chega. Portanto, há limites, critérios, leis, valores a serem obedecidos tanto pelo hóspede, sob o risco de se tornar um intruso, quanto pelo hospedeiro, que se torna refém daquele que acolhe. A hospitalidade pura e incondicional, a hospitalidade em si, abre-se para alguém que não é esperado nem convidado, para quem quer que chegue, como um visitante absolutamente estranho, não identificável e imprevisível, ou seja, totalmente outro. E Ulisses desfruta desta hospitalidade que Alcínoo lhe dedica.

Aqui acontece o grande "flashback" em analepse da obra. Ulisses conta todos os pormenores da viagem, durante o banquete oferecido em sua honra como o estrangeiro de passagem. Parte desta narrativa em retrospectiva é contada pelo próprio Ulisses e a outra pela boca do poeta Demódoco, que vai dando a roupagem heroica aos feitos do herói. Nas palavras do aedo, Ulisses visualiza sua grandeza, obtém o reconhecimento. Demódoco se manifesta como alterego de Homero, oferece como prêmio ao espoliado sua glorificação. Por outro lado, com a narrativa de Demódoco, o herói obtém o que não pôde ter com as sereias, afinal não podia, em hipótese alguma, ser seduzido pelo canto delas, ainda que estivessem enaltecendo a figura dele próprio, o herói.

Ulisses chegara nu à ilha dos Feácios, desgastado, desprovido, exaurido um náufrago, na condição máxima do exilado. Ao ser encontrado na praia por Nausícaa, uma adolescente que se assusta com a imagem daquele sobrevivente destituído de tudo, inclusive de roupas, esta o acolhe, junto às suas pajens, como pessoa. $\mathrm{O}$ indigente é conduzido pela princesa ao palácio, onde Alcínoo o acolhe como um ser superior, tamanha a sua hospitalidade. Durante o banquete, ao fazer esta rememoração, percebemos a perspicácia de Ulisses ao narrar suas experiências; recontando-as, ele revive, relembra e assegura o registro. A filósofa Jeanne Marie Gagnebin endossa esta ideia:

... desde o início, que a luta de Ulisses para voltar a Ítaca é, antes de tudo, uma luta para manter a memória e, portanto, para manter a palavra, as histórias, os cantos que ajudam os homens a lembrarem do passado e, também, a não se esquecerem do futuro (GAGNEBIN, 2006, p. 15). 
São fascinantes as passagens (Canto VIII) em que o excelente Demódoco é reverenciado no Palácio de Alcínoo. Sendo cego, o aedo é continuamente cercado de cuidados. Homero chega a descrever o modo como lhe indicam a localização de sua lira, quando ele a abandona temporariamente para fazer uma refeição. A ele, Ulisses dirige cálidas palavras - "Mais do que a todos os outros mortais, te venero, ó Demódoco" (Od., VIII, 487), chegando a oferecer-lhe um pedaço da própria refeição; sob o som de sua lira e as narrativas do seu canto, relembra os episódios de Troia, e verte muitas lágrimas:

Isso narrava o famoso cantor. Odisseu, entrementes, liquefazia-se em lágrimas, tendo banhadas as faces, como mulher abraçada no corpo do caro marido que sucumbisse a lutar junto aos muros e seus moradores, a defendê-la e a seus filhos da sorte do dia impiedoso. (Od., VIII, 521-525).

A passagem é especialíssima, no que se refere à ontologia do exílio. Por um lado, os aedos cantam para os mortais "palavras cheias de saudade". Ao lermos a Odisseia, sentimos que eles ocupam um lugar diferenciado, que não devem ser "julgados" como os demais humanos. E podemos ter a comprovação deste status diferenciado no episódio da matança dos pretendentes, quando o aedo Fêmio pede para ser poupado e recebe a clemência de Ulisses. Nada como ter o testemunho de concidadãos, quando se necessita de um gesto decisivo, de vida ou morte! Por outro lado, Ulisses chora, porque, ainda que distinguido com grande hospitalidade, ele se vê sem amigos, distante dos concidadãos, daqueles que lhe são íntimos e caros. Este é um sentimento exílico dos mais pungentes, em que o indivíduo é ápolis sem pertencer a uma pólis, professar um credo, comum à coletividade, se expressar numa determinada língua ou dialeto.

Os Feácios decidem, num ato de generosidade e cortesia, enviar uma tripulação de cinquenta e dois homens para levar o herói até Ítaca. Ainda no jantar, falam da Guerra de Troia e contam histórias da mitologia, como a infidelidade de Afrodite a Hefesto e sua vingança.

Ulisses continua a narração de sua viagem, falando sobre o modo como cegou o ciclope Polifemo, filho de Poseidon, que exigiu vingança, desejando que ele nunca voltasse a Ítaca. Conta também a sua passagem pela ilha de Circe, onde a feiticeira droga a tripulação e transforma os homens em porcos; cabendo notar a forma como foi feito um acordo com ela, a conselho de Hermes. A narrativa do 
protagonista da Odisseia fascina a todos no Palácio de Knossos, e o rei dos Feácios descreve este encantamento, nas palavras de Piero Boitani:

elogia sua 'mente egrégia', não tecelã de "histórias falsas que ninguém pode ver", mas capaz de dar 'forma' aos 'relatos'. "Tens - diz Alcínoo - exposto com arte [com perícia, com sabedoria] a tua narração (mythos) como um aedo". Os efeitos da poesia de Odisseu são mais envolventes até do que aqueles obtidos pelo aedo dos Feácios, Demódoco, que provoca alegria ou pranto, e similares àqueles produzidos por Fêmio, o aedo de Ítaca que "encanta os ouvintes" com as histórias da volta dos Aqueus à pátria. Quando o herói termina sua narração sobre o Hades e os Mortos, os Feácios ficam imóveis em silêncio: "estavam dominados por um encantamento, na sala escura". E o próprio Alcínoo desejaria permanecer acordado toda a longa e indizível noite para ouvir as "empresas maravilhosas", as aventuras que Odisseu sabe contar tão bem (BOITANI, 2005. p. XVII).

No Canto VIII, Ulisses vai se aproximando do Ocidente e se afastando do Oriente. Chega à Sicília, onde se situa o país dos Ciclopes $^{12}$, a representação antropomórfica do vulcão Etna. Os ciclopes eram grandes criaturas que possuíam força descomunal e apenas um olho no meio de suas testas. Seu nome vem do termo grego "kýklops", que significa "olho redondo". Tendo origem diversa e aparecendo em vários mitos da Grécia Antiga, estas criaturas são organizadas, de acordo com sua origem, em três diferentes espécies: os urânios, filhos de Uranos e Gaia; os sicilianos, filhos de Poseidon, e os construtores, originários do território da Lícia.

No Canto IX, Ulisses dirige-se a seu anfitrião, Alcínoo, e diz-lhe que vailhe relatar, desde o início, etapa por etapa, suas aventuras, encontra-se na última etapa de seu nóstos e volta para o início da narrativa. Então, conta-lhe quem é e de onde vem (Ulisses, Ítaca). O relato se inicia com a narrativa da sua viagem desde que partiu de Troia, incluindo a rememoração de três etapas de uma só vez. Na primeira parte do relato, relembra a passagem pelos Ciconianos, povo inóspito, guerreiro que não permitiu nem a ancoragem dos navios. Neste episódio, Ulisses e seus marinheiros sentiram o desamparo, o desconforto de não ter casa, apoikia, isto é, a nostalgia, o distanciamento (gr., prep. apó) de sua morada fixa; a sensação de estar vagando sem poder aportar e descer à terra firme em busca de novos suprimentos para seguir viagem. É o desalento! Dando continuidade a seu relato,

\footnotetext{
12 Segundo Virgílio e Eurípides, os ciclopes eram assistentes de Hefesto e trabalhavam dentro dos vulcões junto com o deus, tanto no monte Etna, na Sicília, como em outras ilhas mais próximas. Os dois filósofos não os descreviam mais como pastores, mas como ferreiros que trabalhavam para os deuses e heróis, forjando suas armas. O poder dos ciclopes era tão grande que a Sicília, e outros locais mais próximos, conseguiam ouvir o som de suas marteladas quando trabalhavam na forja.
} 
Ulisses narra a segunda etapa deste percurso presumido, mas não realizado, de volta a Ítaca, e conta a passagem pelo país dos Lotófagos, seres mágicos, sobrenaturais, alucinados, delirantes pois se alimentavam com flores alucinógenas e se tornavam violentos sob o efeito das flores. São átimoi, sem "time", sem honradez, homens desfibrados, desonrados. O risco percebido por Ulisses, na condição de invasor das terras destes seres entorpecidos que viviam em uma realidade paralela, foi assustador, pois confrontava-se com um povo inamistoso, que suscitava um sentimento ruim; o exilado temia não ser bem vindo, o que gera a hostilidade.

Ulisses continua a narrativa, passando à terceira etapa, quando se aproximou da terra dos Ciclopes que viviam em outra parte da Sicília. Aqui dá-se um dos episódios mais conhecidos do nóstos de Ulisses. Os ciclopes são homens gigantescos, que vivem sem lei, como selvagens, trogloditas. Proporcionalmente à violência e à incivilidade (são apolítai, etimologicamente, "sem vivência política": desconhecem o que seja uma “pólis"), enxergam o mundo parcialmente, apenas através dos impulsos. A vida mental precária se expressa fisicamente através da visão monocular e do nome que os descreve como povo. Ulisses, movido pela curiosidade e pelo interesse pelo novo, quer ver e falar com um ciclope. Os ciclopes são pastores de ovelhas e vivem em cavernas, onde dormem com seus rebanhos presos.

Os Ciclopes, exaltados ao perceberem a presença de incursores em seu território, rechaçaram brutalmente os Aqueus. De cada nau morreram seis dos homens de Ulisses. Os sobreviventes foram aprisionados por Polifemo em sua gruta. Sofreram, então, uma ameaça real de tortura, cárcere, sofrimento psicológico e morte, ao verem os companheiros sendo devorados pelo ciclope. Este cenário não intimida Ulisses - ao contrário, excita-lhe a solércia. De início, o itacense conquista, no primeiro contato pessoal, a tolerância do monstro. A seguir, dá-se uma das cenas mais famosas não só da Odisseia, mas talvez a mais emblemática da esperteza de Ulisses e do povo grego: arguido por Polifemo sobre seu nome e a terra de onde vem, o forasteiro responde prontamente: "Oútis". A palavra se traduz por "Ninguém". Ocorre que, em grego, a primeira sílaba, ou, é uma partícula negativa, assim como a partícula me. Desta forma, ou-tis equivale gramaticalmente a $m e$-tis ${ }^{13}$,

\footnotetext{
${ }^{13}$ Perguntado por Polifemo sobre sua identidade Ulisses retruca prontamente: "Oûtis". A palavra se

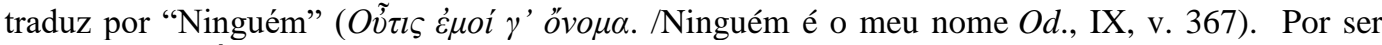
sinônimo de mếtis (Ulisses é o único herói que recebe o epíteto de polýmetis - o engenhoso). Essa
} 
mas não semanticamente, ao contrário, as palavras são antônimas, já que métis é a "astúcia"! O trocadilho ludibria o imbecil. Ulisses sela o diálogo amistoso oferecendo ao tosco ciclope uma garrafa do néctar dos deuses. Já se vê que a imagem amigável de Ulisses é tão hostil quanto a momentânea hospitalidade de Polifemo, inebriado com o vinho grego: "Vou deixar para devorá-lo por último"

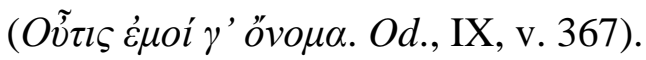

Quando Polifemo dorme, Ulisses pega na espada, mas reconsidera o gesto, porque não poderia depois abrir a entrada da gruta que estava fechada com uma gigantesca e pesada pedra, e terminaria por morrer preso na gruta. No dia seguinte, enquanto Polifemo pastoreava o rebanho, prepara com os seus companheiros, uma grande tora de árvore, afia-lhe a ponta e endurece-a ao lume. Polifemo volta e devora mais dois aqueus. Ulisses oferece-lhe vinho. Polifemo pergunta-lhe o nome ele responde que é "Ninguém". Polifemo agradece-lhe o vinho e diz-lhe que, em retribuição pela bebida, vai deixá-lo como o último a ser comido. Depois, sob o efeito do vinho, o gigante adormece. Então Ulisses e os seus companheiros espetam-lhe a grande lança no olho. Este levanta-se aos gritos. Aparecem outros Ciclopes lá fora a perguntar-lhe o que lhe aconteceu. Ele responde: fui cegado. Eles perguntam: por quem? Polifemo responde: por "ninguém". Em mais um episódio, Ulisses lança mão de sua suprema inteligência para conseguir escapar de mais um infortúnio de seu nóstos. No dia seguinte, os Aqueus e Ulisses penduram-se por baixo das ovelhas. Assim, o Polifemo cego que agarra nas ovelhas uma a uma e as tateia por cima, para as pôr para fora, não se apercebe do estratagema. Fogem assim os que sobraram para as naus ancoradas. Depois de levantarem ferro, Ulisses, a alguma distância da costa, grita injúrias a Polifemo cego. Este, num acesso de raiva, atira-lhe grandes pedregulhos que quase acertam as naus. Esta cena sugeriu a arqueólogos e homericistas que os Ciclopes se localizassem na região do vulcão Etna, ainda hoje em atividade ruinosa, capaz de lançar longe pedras incandescentes.

Ao fugir, inicia seu caminho para o Reino de Éolo, nas Ilhas Lípari, ainda ao largo da Sicília, onde há muita ventania. O vento extremo está sempre rejeitando a aproximação dos estrangeiros, vento que expulsa, dificulta o acesso, funcionando

confusão etimológica na verdade é um jogo para salientar a força do herói, pois quando Polifemo pede ajuda aos seus amigos dizendo que "ô̂tis"o feriu, eles o respondem utilizando a forma $m \bar{e}$ tis para "não alguém”. Esse jogo fonético reforça que na verdade foi a astúcia, a mếtis, e não a força de Ulisses que venceu o gigante. Salienta-se também que a divindade homônima (Métis) é mãe de Atená, deusa da sabedoria e protetora de Ulisses. 
como uma metáfora, um fenômeno natural que adquire características praticamente humanas, tormentoso aos viajantes.

No canto X é a vez de nosso herói se deparar com os lestrigões, monstros antropófagos e abrutalhados que vivem na Lestrigonia, Sardenha. Esta passagem tem uma peculiaridade: provavelmente este povo mítico seja uma imagem poética, plástica que se forma muito arcaicamente em função dos perigos que recaem sobre os navegadores e suas embarcações ao passarem pelo Estreito de Bonifácio, que é uma passagem perigosíssima, em péssimas condições de navegabilidade, entre a Córsega e a Sardenha. Tal passagem é muito perigosa e, não só na Antiguidade remota, mas ainda hoje embarcações espatifavam-se contra as rochas gigantes, porém estreitas, de acesso à costa italiana. É como se as rochas fossem a representação, ilustração do povo agigantado daquela localidade e sua geografia estranha. Ao chegar ao país dos Lestrigões, o exilado enfrenta as dificuldades da sobrevivência: a procura de víveres, a aproximação de um porto hostil, a acessibilidade quase inexistente e que é inviável nesta compleição geográfica desafiadora.

Ulisses consegue a proeza de passar por este local e tem acesso à região setentrional da atual Itália, onde aporta próximo ao Monte Circeu, região montanhosa que possui características peculiares, com águas sulfurosas, cavernas e lugares fantasmagóricos onde vive a temida feiticeira Circe. Trata-se de outra prisão, outra entidade poderosa que se apaixona pelo desterrado e o retém por três anos. Depois de muito coagida, ela admite auxiliar Ulisses num projeto interdito a qualquer mortal: consultar-se com aos mortos. Na verdade, Ulisses venceu-a, com ela lutou e dominou-a, conseguindo, pela força, que ela lhe facultasse o acesso ao local que confinava com o caminho fluvial que daria acesso ao Hades. Neste local mórbido foi que Ulisses realizou a "Nékuia", a "Evocação dos mortos", ritual no qual ele, como evocador vivo, permanece fora, aquém da região necrológica; as almas vêm até ele para lhe falar. Este é um episódio de altíssima densidade místicomistérica: o herói recorre a instâncias sobrenaturais; entrega-se à sabedoria dos mortos, ao risco de ser tragado pelo hálito pestilento do são-se. Mas Ulisses se oferece ao sobressalto por falta de notícias de seus familiares. Ele ali se encontra como o exilado que, desinvestido de autonomia e, em muitos casos, de identidade, passa a viver como um cadáver, como um fantasma. Esta é a sexta etapa do exílio. 
Os barcos remanescentes da frota de Ulisses chegam a Eéia, país de Circe. Uma terra estranha, onde os animais andam sobre duas patas e parecem acenar. Seus homens vão explorar o local, mas Ulisses fica no navio. A feiticeira, especialista em venenos e drogas, recebe a tripulação no seu palácio e serve uma bebida alucinógena. Circe é considerada a deusa da Lua Nova, do amor, do amor físico, da feitiçaria, dos encantamentos, dos sonhos precognitivos, das maldições, das vinganças, da magia negra, da bruxaria e dos caldeirões. A deusa fez seus convivas se assentarem e, servindo-lhes vinho e iguarias, após se divertirem à farta, ao toque de uma varinha de condão, os transforma em porcos, com "a cabeça, o corpo, a voz e as cerdas" de porco, embora conservando a inteligência de homens.

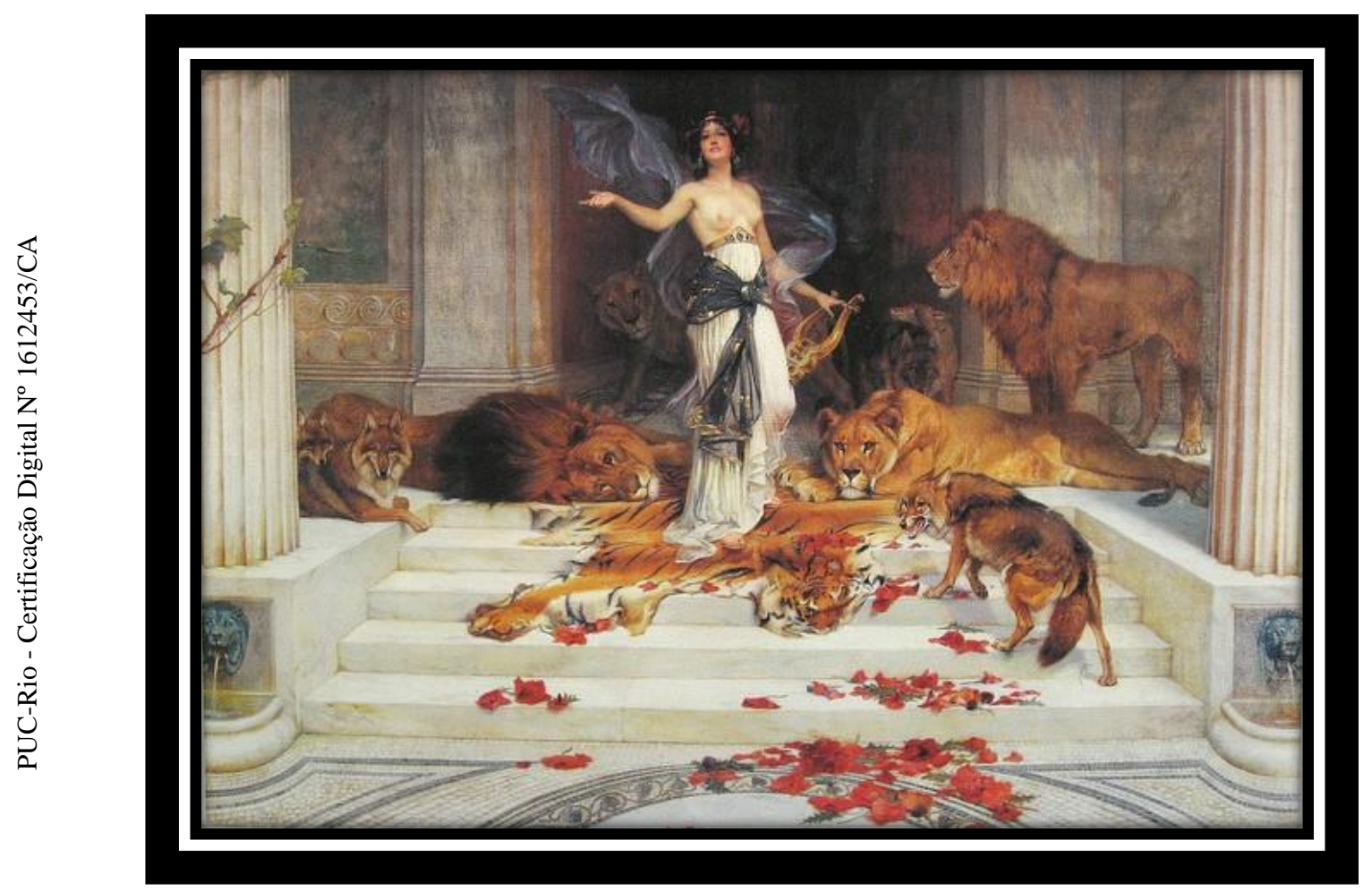

Circe por Wright Barker (1864-1941). Cartwright Hall Art Gallery, Bradford.

Um único deles, Euríloco, que ficou do lado de fora porque estava com medo, vê tudo e corre para contar a Ulisses, que, então, resolveu ir, ele próprio, tentar a libertação dos companheiros. Enquanto se encaminhava para o palácio, encontrou-se com um jovem que se dirigiu a ele familiarmente, mostrando que estava a par de suas aventuras. Era Hermes, que informou Ulisses acerca das artes de Circe e do perigo de aproximar-se dela. Como Ulisses não desistiu de seu intento, Hermes deu-lhe o broto de uma planta chamada Moli, dotada de poder para resistir 
às bruxarias, e aconselha o herói a não aceitar nada da figura misteriosa, mas, sim, fazer um acordo com ela. Aqui é visível que o poder está nas mãos da figura feminina; ao contrário de Penélope, que é "boa", Circe é feroz e implacável.

Quando o marido de Penélope enfrenta Circe, desafiando-lhe os poderes, ela se surpreende com sua coragem e sugere que façam amor. Ele aceita, na condição de que ela desfaça o feitiço e liberte seus companheiros. Depois do ato, a divindade cumpre a sua parte, ensinando o melhor caminho para seguirem e recomendando preces, súplicas e sacrifícios.

O canto XI, onde se passa a cena crucial em que Ulisses se coloca na fronteira entre a vida e a morte, está no meio da obra, é um divisor de águas. Nele Ulisses se modifica, tem uma experiência metafísica e vive a sétima etapa de seu Nóstos. Chega a um local seguindo as instruções de Circe: recita as fórmulas mágicas que fazem com que ele consiga que as almas venham até ele. Este acontecimento é tão especial, que substitui a Catábase ${ }^{14}$, ou seja, mostra que o herói esteve às portas do inferno, foi um privilegiado. Não pisou no Hades. Mas passou pela experiência irrepetível. Fez a evocação ${ }^{15}$, que é o chamado para as almas que vêm ao mundo dos vivos falar com quem as chama. Ocupa o lugar de canto-chave, nódulo central da narrativa in medias res. Neste encontro, Ulisses recebe instruções das almas do pai, da mãe, de Tirésias, de Agamemnon, de Elpenor e de outras celebridades do além-túmulo micênico. Para finalizar o mórbido happening, assiste a um desfile de filhas e esposas de heróis que morreram, vítimas dos conflitos.

É muito importante frisar que este é o episódio que organiza a montagem da obra. Mas esta organização não foi escolhida por Homero; quem assumiu esta tarefa foram os Pisistrátidas (filólogos, coletores das rapsódias antigas, revisores, fixadores dos textos homéricos), elite intelectual a serviço dos projetos do tirano ateniense Pisístrades, já mencionado.

\footnotetext{
${ }^{14}$ Catábase (do grego $\kappa \alpha \tau \grave{\alpha}$, "baixo", $\beta$ aivw, "ir") corresponde a qualquer forma de descida. Porém, na mitologia o termo é usado para se referir à descida ao mundo inferior (mundo dos mortos). Vários personagens na literatura baixaram aos infernos, como Orfeu, Ulisses, Aquiles, Eneias e mesmo Dante, na obra Divina Comédia. Em geral, o herói descia ao mundo dos mortos com o propósito de consultar os mortos, a fim de obter conhecimento. A verdadeira catábase deve ser seguida de uma anábase (ou o movimento de saída do mundo dos mortos), pois do contrário passa a se tratar de morte, e não genuína catábase.

${ }^{15}$ Evocação (do latim, evocatione), em termos gerais e na Psicologia, é o ato de relembrar um fato ou a atualização dos dados fixados; em religião e misticismo é o chamamento por meio da magia para que certa entidade se manifeste à frente do magista sem tomar controle de sua consciência, diferente da invocação, onde a entidade toma lugar e controle do corpo e mente do espírita.
} 
Circe aparece novamente para guiar a tripulação, avisando sobre os perigos no caminho. Mais adiante, no canto XII, Circe surge de novo para aconselhar e guiar a tripulação. Suas palavras indiciam desgraças, embora prevejam a sobrevivência de Ulisses. Entre a indicação das ameaças fantásticas que vão cruzar o seu caminho, Circe alerta o herói sobre as sereias. As figuras monstruosas, que na época eram imaginadas como uma mistura de mulher e pássaro, atraiam os navegadores com o seu canto e os devoravam.

Quem quer que, por ignorância, vá ter às Sereias, e o canto /delas ouvir, nunca mais a mulher nem os tenros filhinhos/ hão de saudá-lo contentes, por não mais voltar para casa./ Enfeitiçado será pela vos das Sereias maviosas/Elas se encontram num prado; ao redor se lhe veem muitos ossos/de corpos de homens desfeitos, nos quais se engrouvinha a epiderme./Passa de largo, mas tapa os ouvidos de todos os sócios/com cera doce amolgada, porque nenhum deles o canto possa escutar.( $O d$., XII, 41-48; 2015, p. 204.).

Aconselhado pela divindade, Ulisses manda seus homens colocarem cera nos ouvidos para não escutarem nada. Sempre curioso e sedento de conhecimento, pede que o amarrem ao mastro da embarcação e não o soltem, mesmo que implore. Amarrado ao mastro, consegue resistir ao canto das sereias. Depois derrota Cila, um monstro marinho que devora alguns dos seus homens.

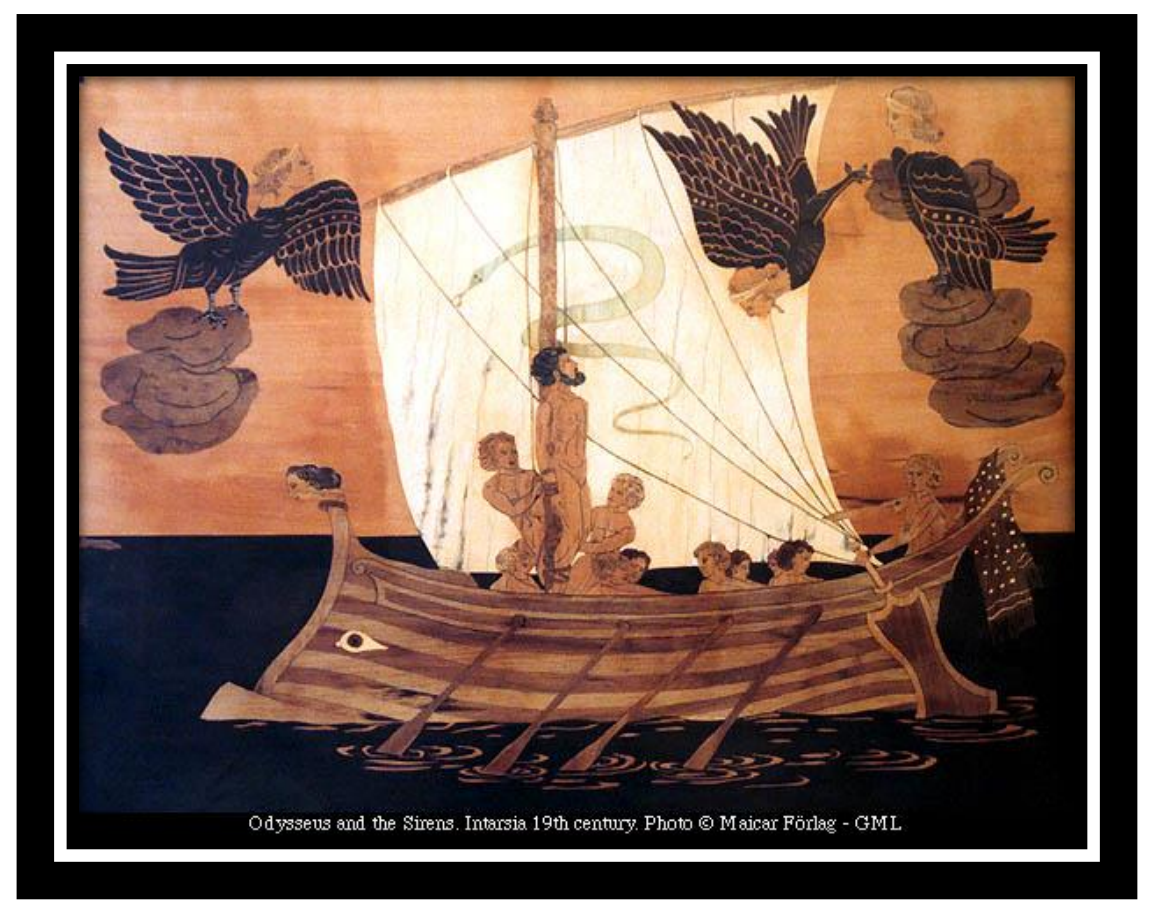

Odysseus and the Sirens. Intarsia 19th century. Museo Correale de Terranova, Sorrento. 
No canto XII, o herói retorna à ilha de Circe e, outra vez, torna-se refém dela. Lutam, mas Ulisses a vence. Para não a matar, fazem um acordo em que o herói é libertado. É o último canto das aventuras no mar. Em seguida enfrenta o episódio das sereias, que acontece na Costa do Mediterrâneo, na parte setentrional da Itália, região conhecida pelo assédio de piratas, tão perigosos quanto as sereias (que parecem, aliás, representá-los).

Chegam ao reino de Hipérion, o deus Hélios, sempre ensolarado e muito hospitaleiro, onde é imposta apenas uma regra: a de não tocar nos bois, nos rebanhos do Sol. Continua a rememoração de Ulisses, que chega à décima aventura: os marinheiros tocaram nos bois, pois estavam famintos. Um exemplo específico em que os companheiros de Ulisses perderam seu nóstos foi este, quando comeram o gado de Hélio e foram mortos por isso, pois tinham sido especificamente instruídos a não o fazer. Ulisses avisou os homens quando disse:

\begin{abstract}
"Caros amigos! Na nave ainda temos comida e bebida;/cumpre pouparmos as vacas, não vá suceder-nos desgraça./De divindade terrível são todas, e as nédias ovelhas,/ de Hélio, que tudo discerne e que todas as coisas escuta."/ "Dessa maneira falei, convencendo-lhes o ânimo altivo./ Noto soprou pelo curso de um mês, incessante; dos outros/ ventos nenhum nos soprava, a não ser Euro e Noto, somente./Eles, enquanto ainda tínhamos vinho vermelho e alimentos,/ nada aos rebanhos fizeram, por terem amor à existência./ Quando, porém, se acabou tudo quanto se achava na nave,/ a percorrer a ilha toda se viram forçados, em busca/ de algumas aves e peixes, munidos de anzóis retorcidos,/ ou do que achassem, que o estômago a todos a fome afligia." (Od., Canto XII, V320-332. p. 212 2015).
\end{abstract}

Desobedeceram e foram punidos com a perda da vida. Perderam também a grandeza do nóstos porque sua jornada para casa terminou.

A etapa seguinte é a chegada a Ogígia, um ritornello ao Canto V.

Encontramo-nos, entretanto, no Canto XII, ponto do poema em que Ulisses parte de Ogígia para a última aventura - a estada em Knossos - antes de desembarcar em Ítaca. 


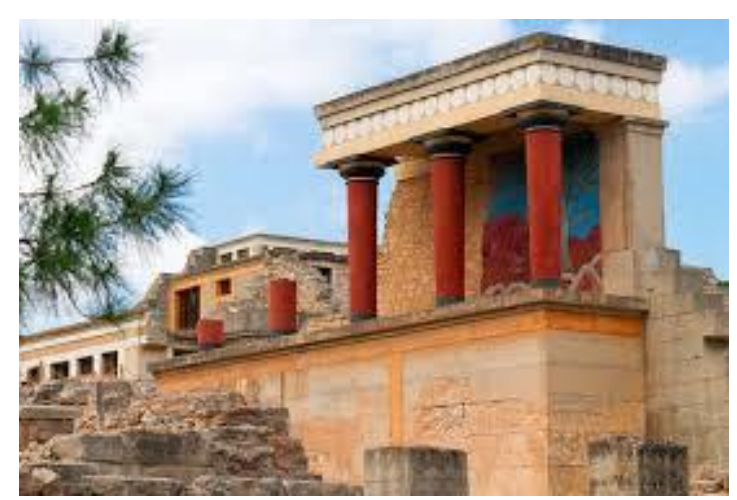

À esquerda: Palácio de Knosso, Heraclião, Creta. Varanda com painel pintado. À direita: Reconstituição do Palácio de Minos

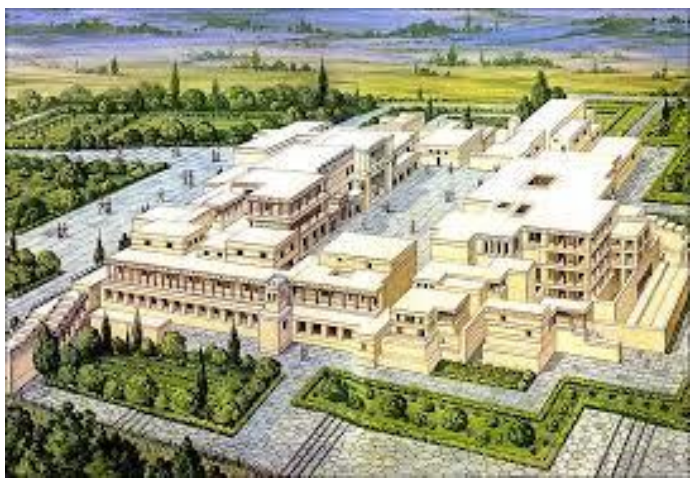

Junto aos Feácios, Ulisses começa a desfrutar da fama adquirida em suas tribulações e aventuras. O tempo do exilio foi longo, mas dá sinais de que está terminando. As agruras enfrentadas, as ameaças, a submissão, a carência de direitos e prazeres deixou suas marcas. Antes de voltar para Ítaca, tratado como hóspede, Ulisses é reconhecido e chora os perigos enfrentados.

A última etapa das aventuras marítimas coincide com a derradeira oportunidade para que Poseidon executasse a sua vingança pelo que Ulisses fez no país dos ciclopes: além de ridicularizar a rusticidade dos habitantes, mutilou a seu filho Polifemo, cegando-o. É quando Ulisses se vê sozinho em uma jangada, sob a ira de Poseidon. Após este episódio, chega ao reino dos Feácios, como visto anteriormente, sem barco, nu, desfalecido.

Aqui se inicia a partida para Ítaca, que ainda faz parte da narrativa no ambiente maravilhoso, mítico. Depois da hospitalidade autêntica, com todos os requisitos e carismas, Ulisses recebe de Alcínoo - que também é uma representação do Hades - orientações, instruções para sua viagem de nóstos ${ }^{16}$ a Ítaca para que

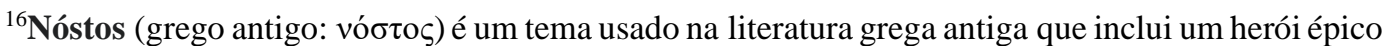
voltando para casa por mar. Na sociedade grega antiga, era considerado um alto nível de heroísmo 
chegasse são e salvo. Tendo aconselhado Ulisses a reagir da forma mais sensata e sábia aos acontecimentos durante a viagem, Alcínoo prepara uma nau, vastas provisões e fornece grandes e hábeis marinheiros. É o grande prêmio que ele recebe pela prudência, astúcia e inteligência demonstradas nos dez anos de provação de seu nóstos.

O Canto XIII é dedicado à chegada a Ítaca. A obra se divide em duas partes: 12 cantos no mar maravilhoso, na esfera do mito, e 12 cantos no âmbito da humanidade, na árida, escarpada, inóspita Ítaca.

Ao chegar a Ítaca o navio é transformado num rochedo. Para entrar em consonância com a atmosfera seca, estéril da ilha. A partir deste ponto, sai da esfera dos suplícios para o patamar das ações imperativas. Nesta passagem, o protagonista se humaniza, é o despertar de Ulisses.

Ulisses desembarca anônimo e vai se esconder em casa de Eumeu, um criador de porcos e servo fiel de sua família. Atená procura Telémaco e o convence a regressar, avisando que os pretendentes preparam uma emboscada. O jovem regressa a Ítaca durante a noite e vai para casa de Eumeu, como a deusa ordenara.

Canto XIV, a vingança. Eumeu e os encontros. Ulisses chega à cabana do porqueiro Eumeu. Os cães do porqueiro correm, aos uivos, em perseguição ao visitante, disfarçado de ancião, além de mendigo - consoante o combinado junto à deusa Atená. Eumeu espanta os cães que se encontravam próximos - sobretudo em defesa do porqueiro; bem recepcionando, em seguida, entra o estrangeiro, que, na verdade, era o próprio senhor, irreconhecível devido ao disfarce.

Ulisses, visando logo ganhar a simpatia do porqueiro Eumeu, diz, ardilosamente, que estrangeiros e mendigos são enviados de Zeus. Eumeu convida, então, o faminto disfarçado a entrar na cabana. Em seguida, Ulisses, junto a Eumeu, alimenta-se na cabana do porqueiro.

Eumeu passa a se recordar do patrão - Ulisses - junto ao recém-chegado hóspede, demonstrando incredulidade quanto a um possível retorno do herói a Ítaca.

ou grandeza para aqueles que conseguiam retornar. Essa jornada geralmente é muito extensa e inclui ser naufragado em um local desconhecido e passar por certas provações que testam o herói. O retorno não é apenas sobre voltar para casa fisicamente, mas também sobre manter certos status e manter sua identidade na chegada. O tema de Nostos é trazido à vida na Odisseia, de Homero, onde o herói principal Ulisses tenta nostos voltar para casa depois de lutar na Guerra de Troia. Ele é desafiado por muitas tentações, como as sereias e os comedores de lótus. Se o heroi tivesse cedido a essas tentações, isso significaria morte certa e, portanto, deixaria de voltar para casa. Nostos é usado hoje em muitas formas de literatura e filmes. 
O mendigo-ancião insiste que o herói voltará. Eumeu pede, então, que o mendigo narre a sua própria história. $\mathrm{O}$ ardiloso Ulisses começa, então, a contar a sua história para o porqueiro. $\mathrm{Na}$ verdade, o astuto Ulisses inventa uma narrativa, dizendo, ao seu fiel porqueiro Eumeu, ter nascido na vastíssima Creta. E prossegue, narrando uma série de infortúnios por ele enfrentados. Por isso abandonou Creta e foi para o Egito. Porém, quando se encontrava no Egito, um forasteiro fenício o logrou com astúcia, convencendo-o a levá-lo para a Líbia. Durante a viagem, a embarcação naufragou, aportando na terra dos homens Tesprotos, onde reinava Fidão, $\mathrm{O}$ valoroso. Fidão informou ao ancião que, ali, Ulisses acumulava imensa fortuna e que, justamente naquele exato momento, ele havia partido para Dodona, a fim de consultar o oráculo de Zeus, deus do Olimpo, sobre a maneira melhor de retornar para a sua tão sonhada Ítaca.

$\mathrm{O}$ astuto porqueiro, entretanto, não acredita na história narrada pelo ancião; passa, então, a lamentar a ausência do patrão Ulisses e se refere, entristecido, aos infindáveis infortúnios reservados tanto a Penélope quanto ao filho do herói, Telêmaco. Em seguida, o prudente ancião recrimina o porqueiro Eumeu por não acreditar no retorno de Ulisses e, depois, ambos fizeram juntos uma refeição.

Os céus reservavam uma terrível tempestade, pronta a desabar. Logo a seguir, passou a chover fortemente, e um terrível frio enviado pelo vento Bóreas invadiu a choupana.

A essa altura, o ancião - sempre garantindo falar somente a verdade -, aproveitando-se da ocasião propícia, volta a narrar, dizendo como vivenciou, na condição de guerreiro, a sua participação na Guerra de Tróia, além do contato que lá fizera com Ulisses. O manhoso visitante, ou melhor, o "ancião-mendigo" conta a Eumeu que, durante a guerra, o astucioso Ulisses oferecera-lhe mantos para que este se protegesse do intenso e gélido frio.

Finda a narrativa, o porqueiro Eumeu agradeceu ao ancião pela bela história, oferecendo, em seguida, ao hóspede, mantos, no intuito de proteger o "ancião" do frio que invadira, há pouco, a choupana. Ambos então caíram em sono profundo. Eumeu deixou a humilde cabana, indo deitar-se, segundo o hábito, junto aos porcos, debaixo de uma côncava pedra, ao abrigo do vento Bóreas.

O Canto XV narra a chegada de Telêmaco. Ulisses tem que ser reinserido em seu país. O escravo e porqueiro participam dinamicamente desta reintegração que ocorre primeiro no nível dos escravos, em segundo no dos inimigos e apenas 
por último com Penélope. A aproximação se dá em três etapas gradativas, fazendo com que, mais uma vez, Ulisses use sua sapiência e prudência, a fim de atingir seu intento.

Telêmaco ainda se encontra em Esparta, junto ao caro filho do herói Nestor, Pisístrato. Durante a visita que fizera a Esparta, além dos conselhos que recebera tanto de Menelau quanto de Helena, Telêmaco ganhara, também, do divino casal, valiosos presentes. Porém, antes da partida do ajuizado jovem Telêmaco (antecipada e tramada pela deusa Palas Atená) da cidade espartana, Helena teve um presságio: avistou uma águia, levando consigo um ganso capturado e indefeso. Helena decifrou o presságio a Telêmaco, isto é, confirmou o retorno de Ulisses a Ítaca, seguido da matança, pelo herói grego, de todos os pretendentes que haviam se apossado de sua casa no reino de Ítaca, consumindo seu patrimônio.

Telêmaco embarcou em sua nau, no entanto, surge um contratempo: um estrangeiro de nome Teoclimeno se aproxima da embarcação, narrando ao filho de Ulisses sua infeliz história como fugitivo da própria pátria, por ter assassinado um outro homem. Após ter ouvido a história de Teoclímeno, Telêmaco o convida a sentar-se ao seu lado, no bojo da nau.

Enquanto isso, na cabana do porqueiro, o solerte Ulisses desejava comprovar, ou melhor, desafiar a confiança depositada pelo porqueiro em seus familiares. Apresentando como pretexto o desejo de ir até a cidade, o "mendigoancião" conseguira, ardilosamente, atingir o seu objetivo: ouvir a história do porqueiro Eumeu.

Assim, Eumeu passa a narrar ao falso ancião todo o carinho que havia recebido de Anticleia - mãe de Ulisses -, da infância até a adolescência. Porém, numa determinada ocasião, vivendo no palácio de Laertes - na qualidade de escravo privilegiado -, abruptamente, seu destino sofreu uma profunda mudança, pois fora determinado, pelos patrões, a deixar o palácio de Ítaca, para trabalhar no campo. Nesse momento, Ulisses solicitou ao porqueiro maiores detalhes sobre aquela história. Eumeu passou, então, a narrar uma longa história: nascido na Síria, na cidade de Sidão - rica em bronze-, era filho de Aribante, mulher possuidora de incalculáveis fortunas, porém infiel ao marido junto aos astutos homens fenícios. Devido às sucessivas desventuras da mãe, Eumeu foi encontrado abandonado nas praias de Ítaca, e recolhido ao palácio de Laertes, na condição de escravo. 
Enquanto ambos dialogavam, com o auxílio da deusa Atená, Telêmaco regressa a Ítaca, dirigindo-se - no intuito de se esquivar dos ataques dos pretendentes e da emboscada mortal que lhe prepararam - diretamente para a cabana do porqueiro Eumeu, conforme aconselhara a deusa Palas Atená. Telêmaco não tardou em chegar ao estábulo onde se encontravam o pai - disfarçado de ancião - e o porqueiro.

No Canto XVI se dá o reconhecimento de Ulisses pelo filho e a volta ao palácio, ainda sob disfarce e na condição de reconhecer o terreno e mapear a estratégia de retomada do lar.

Telêmaco é recepcionado com grande alegria pelos cães do porqueiro Eumeu, que logo o reconheceram, pois não ladraram um só instante. O porqueiro, avistando Telêmaco, corre a abraçá-lo, com carinho, cheio de afeto para com o amo, saudando-o, tal como um amoroso pai, com doces palavras: "Luz de meus olhos, voltaste, Telêmaco?” (Od., XVI, v. 23)

O ajuizado Telêmaco, uma vez acomodado na cabana, pergunta, então, a Eumeu, quem era, afinal, aquele ancião estrangeiro que se encontrava em sua companhia. Eumeu em resposta diz, referindo-se ao "ancião", tratar-se de um infeliz cretense. Telêmaco, indignado, não se conforma com a presença do "mendigo-ancião" na cabana, e passa a repreender o porqueiro por ter permitido a permanência daquele desconhecido no local.

Imediatamente, o "ancião" tece, um louvor ao herói Ulisses. Após ouvir o elogio dirigido ao pai desaparecido, o prudente Telêmaco replica, narrando os tristes acontecimentos que têm como palco o seu reino, atingindo diretamente a ele e à própria mãe - a fiel Penélope.

Telêmaco pede (temendo as represálias preparadas pelos pretendentes), então, que o fiel Eumeu se dirigisse até o palácio de Penélope, a fim de comunicar à mãe (que aflita aguardava o retorno do filho, pois tudo sabia das piores intenções dos usurpadores do reino de Ítaca em relação ao filho) quanto a sua chegada - a salvo das emboscadas dos pretendentes - à ilha de Ítaca.

Repentinamente, surge a deusa Atená para dizer a Ulisses que chegara a hora de revelar toda a verdade ao filho Telêmaco. A deusa promove uma metamorfose no herói, destituindo-o, dessa maneira, da aparência de ancião e de mendigo e, ao mesmo tempo, restituindo-lhe a antiga aparência vigorosa e tenaz de autêntico guerreiro e Rei de Ítaca. 
Telêmaco, ainda surpreso com a repentina mudança, pergunta ao metamorfoseado ancião se ele era um deus. E este responde que era seu pai. Telêmaco nega-se a acreditar. Então Ulisses diz ao amado filho: "Nenhum dos deuses eu sou; por que a um deus imortal me comparas?

Sou, sim, teu pai, por quem hás suspirado, saudoso, já tanto e tantas dores sofrido, aguentando a violência de estranhos (...)

[ante as dúvidas que Telêmaco lança contra a verdadeira identidade do 'ancião', Odisseu retruca:] (...) Sou, sim, eu mesmo, que após sofrimentos e viagens inúmeras, vinte anos já decorridos, ao solo da pátria retorno. Essas mudanças, que vês, são trabalhos de Atena guerreira (...)

É muito fácil aos deuses, que moram no Olimpo muito amplo, os homens todos mortais exaltar, ou disformes deixá-los" (Od., XVI. V. -202-212).

Uma vez proferidas tais palavras, em prantos, pai e filho se abraçam.

Telêmaco diz, então, ao pai, que os pretendentes ao trono de Ítaca são numerosos, citando alguns nomes. Ulisses pede a Telêmaco que acredite nos deuses e o ajude a retomar ao seu palácio. Assim, a matança dos pretendentes começa a ser tramada. A primeira providência de ordem tática de Ulisses endereçada ao filho é que Telêmaco zele pelas armas do deus Ares (deus das guerras, das armas) escondidas no palácio de Ítaca. Adverte, também, Telêmaco que ninguém poderia saber de sua presença em Ítaca, nem mesmo aqueles que mais desejam o seu retorno, isto é, o estimado pai, Laertes, a fiel esposa, Penélope e o fiel porqueiro Eumeu.

Se és do meu sangue e meu filho te orgulhas de ser, em verdade, não venha nunca ninguém a saber que Odisseu está em casa.

Que o não perceba Laertes, nem mesmo o divino porqueiro, nem um qualquer dos criados da casa, nem mesmo Penélope.

Os sentimentos das servas somente nós dois sondaremos.

Sim, poderemos, também por à prova o sentir de alguns servos, a fim de vermos qual nutre por nós amizade e respeito, e os que de nós não se importam, mostrando por ti só desprezo" (Od. XVI, v. 300-308).

Enquanto isso, os desaforados pretendentes encontravam-se reunidos na Ágora, para deliberar sobre o destino do jovem Telêmaco. A astuciosa Penélope, sabendo de tal acontecimento, interpela o pretendente Antínoo - o mais audacioso destes -, pedindo que cessasse de tramar tamanhas covardias contra seu filho; bastavam os infortúnios que desabavam sobre o palácio durante a longa ausência do marido. Por seu lado, Eurímaco - outro pretendente - dirige um falso discurso a Penélope, prometendo colocar Telêmaco a salvo contra a insolência de todos os 
demais pretendentes que estavam no palácio. Por seu turno, o porqueiro Eumeu retorna à cabana, dizendo a Telêmaco que comunicara à mãe sobre o seu retorno.

No Canto XVII continua a sequência de reconhecimentos. Telêmaco exprime a Eumeu o seu desejo de ir até a cidade, pois queria retornar ao palácio e permanecer junto à mãe; diz, também, ao porqueiro, para se desvencilhar do "mendigo", pois a permanência desse tipo de indivíduo tem lugar na cidade, e não no campo. O "ancião" concorda prontamente com o sábio conselho de Telêmaco.

Chegando ao palácio, Telêmaco pede à mãe que se recolha aos seus aposentos, pois não queria ser incomodado pelos seus gemidos, uma vez que estes o colocavam em sobressalto. Após tantos perigos vividos, precisava repousar. Penélope concorda com o filho, confessando que, naquele momento, sentia-se bastante angustiada com tão longa ausência de Ulisses. Antes, contudo, Telêmaco relata à mãe, em detalhes, a viagem que fizera a Pilo e a Esparta. Não desejando nada ocultar da própria mãe, Telêmaco disse o que soubera, por intermédio da boca de Menelau, quanto ao relato do ancião do mar (Proteu), o qual afirmara que Ulisses se encontrava retido na ilha de Ogígia, junto à ninfa Calipso.

Nesse entremeio, o fiel porqueiro Eumeu torna-se - até a cidade - o guia do herói disfarçado, Ulisses. Ao chegarem a Ítaca, antes de entrarem no palácio, o filho de Laertes (ainda com as vestes de mendigo) foi injuriado por Melântio, que se encontrava próximo do bosque das ninfas. Eumeu rogou vingança às ninfas contra Melântio.

Após este episódio, Eumeu e Ulisses rumaram ao palácio. Lá chegando, ambos ouviram o aedo Fêmio a cantar. Um cão aproxima-se de Eumeu e de Ulisses: era Argos, o fiel cão do herói grego. Após longos vinte anos de ausência, deparando-se repentinamente com o dono, o fiel cão se aconchega aos pés de seu amo e morre, a espera dele havia acabado.

Depois desse lamentável infortúnio, Ulisses e Eumeu entram, finalmente, no palácio. Eumeu instrui o Rei de Ítaca a mendigar junto a todos os pretendentes; Palas Atená incita, também, o herói (ainda disfarçado) a mendigar. Na verdade, tratava-se de um valioso estratagema utilizado pela deusa de olhos glaucos, permitindo, desse modo, que Ulisses viesse a conhecer e analisar o comportamento de cada um dos pretendentes, seus inimigos e invasores de sua casa. Tem ainda uma última experiência de exilado, pois não lhe interessa mostrar-se, é mais prudente não se identificar, ainda deve manter-se incógnito. Tem primeiro que reconquistar 
seu território, uma vez que esta reaproximação significa o reempossamento de seus bens, de sua esposa e de sua identidade.

Antínoo foi o mais soberbo e o mais arrogante dentre todos os pretendentes, pois investiu com dura hostilidade contra a presença do "ancião" no palácio. Antínoo torna-se colérico diante de uma resposta insolente que ouve da parte do "mendigo-ancião". Em contrapartida, o "mendigo" profetiza, então, a morte de Antínoo, fazendo uso das seguintes palavras: _ Antes do casamento, encontrarás a morte, Antínoo!

Pressentindo algo, Penélope solicita a presença imediata do "mendigo" em seus aposentos. Mas é desaconselhada pelo porqueiro Eumeu a insistir em tal decisão, tendo em vista as maldosas opiniões alheias com relação a tal procedimento.

Num determinado momento, Telêmaco dá um forte espirro. Penélope ri, profetizando o seguinte: o espirro é sinal dos deuses, e pode, talvez, significar que a morte atingirá a todos os meus pretendentes.

Inicia-se o Canto XVIII - Melântio e Eurímaco. Eures - o que mata com ódio. São os reconhecimentos. Trata-se da passagem em que Ulisses está mapeando o terreno, fazendo o reconhecimento de sua propriedade e de todos os que merecerão ou não permanecer vivos.

Iro insulta Ulisses. Os pretendentes sugerem um combate entre os dois mendigos. Todos se surpreendem quando o disfarçado Ulisses tira a camisa e mostra um corpo bastante musculado. Ulisses, então, aplica uns golpes e parte o queixo de Iro.

Canto XIX: Euricleia, a ama de leite, reconhece o visitante pela cicatriz na coxa adquirida numa caçada ao javali. Cicatriz que foi tratada com amor de mãe e permanece indelével na memória da velha serva.

Ausentes os pretendentes, Ulisses manda que seu filho esconda as armas que houver no palácio. Atena guia-o, empunhando um facho. Penélope repreende a escrava Melanto, por haver insultado o mendigo. Penélope interroga o estrangeiro acerca de sua naturalidade e, perante recusa dele em responder, insiste de novo. Ulisses acaba por condescender. Penélope ouve com emoção a narrativa do hóspede, que declara ter visto o pai de Telémaco em Creta. A rainha põe à prova a sinceridade do mendigo, que lhe anuncia o próximo regresso de Ulisses. Penélope ordena à velha Euricleia que lave os pés do mendigo. Euricleia reconhece seu amo 
por uma ferida que ele tem na perna. Ulisses intima-lhe que guarde silêncio. Penélope conta ao mendigo um sonho que parece anunciar o regresso do esposo. Propõe-se, com a aprovação do mendigo, estabelecer um concurso entre os pretendentes, aquele que conseguir manusear o arco de Ulisses e honrar tal objeto será o vencedor e o escolhido por Penélope.

O Canto XX narra o dia do empossamento de Ulisses nos seus direitos e propriedades e junto à esposa. Há uma intrigante ironia na organização providenciada para recepcionar o estrangeiro que está sendo recebido em sua respectiva casa. Cabe ressaltar a serenidade de Ulisses ao passar por mais esta provação em sua própria casa.

A felicidade do retorno - nenhum deus o ignora- não encontra epílogo no desembarque. Haja vista os casos daqueles que, de volta ao lar, não são reconhecidos pelos parentes nem pelos amigos. A longa permanência fora de casa tanto desfigura o rosto e o corpo como altera a marcha, corrompe o sotaque, modifica os costumes, tornando estrangeiro, e até irreconhecível o infeliz retornado. Não foi o que aconteceu a Ulisses?

Desembarcado em Ítaca, na sua pequena e querida Ítaca, ninguém o reconhece. Nem o seu pai, Laertes, nem o seu filho, Telémaco, e sequer a sua bem-amada Penélope descobre sob os andrajos do peregrino "o divino Odisseu". Apenas ao faro de um velho cão, o seu cão Argos, não passa despercebida a sua presença. Já à morte, deitado num monte de estrume, festeja-lhe a chegada com um leve abano de cauda. (QUEIROZ, 1998, p. 42)

A cena entre os dois mendigos - Ulisses, atuando como falso mendigo, e Crisipo, mendigo real, desmerecendo-o - despoleta a tensão entre as personagens, que se expande para os pretendentes e destes para o circuito dos empregados e dos familiares ${ }^{17}$.

Ulisses não consegue dormir. Sente-se tentado a punir as escravas, mas contém-se e contemporiza. Atená adormece-o. Penélope lamenta sua desgraça. Ulisses pede a Zeus que lhe envie dois presságios: sua prece é atendida. Telêmaco dirige-se à assembleia. As escravas procedem à limpeza da casa; os pastores chegam, trazendo suas vítimas. O cabreiro Melântio quer expulsar de casa o estrangeiro; o pastor Filécio interessa-se pelo infeliz estrangeiro e fala-lhe de Ulisses em termos comoventes. Um sinistro presságio inquieta os pretendentes, que desistem do projeto de matar Telêmaco. Este fala, como dono da casa, que ninguém

\footnotetext{
${ }^{17} \mathrm{O}$ efeito de tensão progressiva é criteriosamente obedecido, retorno do chefe do oíkos - pater famílias, do basiléus daquela ilha, do único que ali tem direito a se aproximar de Penélope
} 
insultará impunemente seu hóspede. Sacrifício e refeição. Agelau exorta os pretendentes a que se mostrem calmos e aconselha Telêmaco a apressar o casamento de sua mãe. Teoclímeno, hóspede da casa, levanta a voz e prediz a desgraça que impende sobre os pretendentes. Aproxima-se a hora do castigo.

No Canto XXI, acontecem as provas. Primeira prova - de força física. A prova do arco -- travestido de mendigo, Ulisses busca recuperar o arco. Objeto mágico, de acordo com o imaginário arcaico, tudo o que é criado tem alma própria. Pela teoria do nomen numen (nome numinoso, sagrado), todos os entes têm um nome sacral; há uma potestade que rege a existência de cada objeto. $\mathrm{O}$ arco é um objeto cuja sacralidade se liga à origem e destinação do objeto. Por isso, um objeto se torna incomum e pode compartilhar da personalidade de seu dono, sendo os dois parceiros e co-proprietários de uma identidade. Apenas Ulisses conhece a identidade numinosa do arco. Por isso a arma só se deixa manipular por ele. Para corroborar esta afirmação Maria José de Queiróz diz que "a identidade se atesta com os atos. $O$ [seu] exílio (de Ulisses) só termina quando os adversários descobrem que ele, Ulisses, e ninguém mais senão ele, seria capaz de tão extraordinárias proezas.” (QUEIROZ, 1998, p.42).

A prova a que Ulisses é submetido para reconquistar sua propriedade e sua casa era atirar uma flecha que atravessasse um orifício aberto nos cabos de doze de machados dispostos em cruz, emparelhados lado a lado; uma única flechada teria que perpassá-los todos de uma vez só. Este seria um feito praticamente impossível, porque aquele arco somente se deixaria fletir por seu proprietário, Ulisses. E ele o faz! Deixando a todos os pretendentes e demais presentes perplexos!

No Canto XXII, Ulisses tira o disfarce e se revela.

Os últimos momentos da Odisseia são marcados por um verdadeiro banho de sangue. É no Canto XXII que Ulisses finalmente se vinga daqueles que faziam a corte à sua mulher, a manhosa Penélope, e se locupletavam com seus bens. Depois de uma ausência de quase vinte anos, o herói encontra seu palácio em Ítaca infestado de parasitas que lhe desonram o nome (o bem mais valioso para os gregos) e arruínam suas posses em meio a banquetes e jogos, os pretendentes. A ira do herói é incentivada pela deusa Atená, através de pequenas interferências que têm por objetivo manter acesa a chama do ódio.

Homero constrói as cenas de modo a ampliar paulatinamente o sentido de humilhação e desrespeito sofridos por Ulisses. Ficamos sabendo que os 
pretendentes planejam o assassinato de seu filho (Telêmaco) e que se esbaldam em amores espúrios (muitas vezes não consentidos) com as servas do palácio. Metamorfoseado em mendigo, Ulisses pode testemunhar com os próprios olhos o ocaso do seu lar. Além disso, uma vez que é tomado por um estranho, torna-se ele próprio alvo da zombaria e do temperamento sórdido dos pretendentes que se apossaram de sua casa. Com a aparência de um velho, vestido com trapos imundos, o orgulhoso herói é escorraçado pelos jovens aristocratas que cobiçam sua mulher.

Mas Ulisses não perde a calma; ao contrário de Aquiles, não se deixa dominar pela ira. Acumula pacientemente o seu ódio; com auxílio de sua protetora divina, Atená, planeja meticulosamente o assassinato de todos os pretendentes. Pelos cálculos do helenista Bernard Knox, Ulisses comanda a chacina de 108 homens, mortos de uma só vez. Eles estão encurralados no interior do palácio, as possíveis saídas foram bloqueadas, as armas que ficavam expostas - e que poderiam ser usadas num possível contra-ataque - foram astuciosamente recolhidas. Com poderes ampliados pelos deuses, Ulisses persegue as vítimas como se fossem ratos sitiados

Homero folga nas descrições da matança: o primeiro assassinado é Antínoo, morto por uma flecha "atravessando-lhe a ponta da flecha o pescoço macio" (Od., XXII, v. 16); o cadáver inclinou-se para o lado "Do nariz escorreu logo um jorro de negro sangue. Batendo com o pé, joga a mesa, violento, longe de si, derramando no solo os manjares variados" (Od. XXII, v. 18-20). Quase no fim da festa, Ulisses nega o perdão a uma das vítimas, Líodes, decepando-a sem misericórdia; Homero complementa: "Ainda a falar, a cabeça rolou para o meio da poeira" (Od, XXII, v.329). O acerto de contas com as servas desleais - que se amancebaram com os pretendentes e insultaram a família de Ulisses - é de uma crueldade ímpar: Telêmaco nega-lhes uma "morte limpa", optando pelo enforcamento "Com cordas pelo pescoço, porque mais depressa morressem. Por pouco tempo, não muito, batendo com os pés, estrebucham" (Od. XXII, v. 471-472).

Ainda pior é a morte que encerra o famigerado Canto XXII: a morte de Melântio, o pastor infiel que havia ofendido Ulisses. Os criados o mutilam e matam barbaramente: “cortam-lhe, logo, com bronze cruel o nariz e as orelhas, os genitais lhe arrancaram, aos cães atirando-os sangrentos, e as mãos e os pés, afinal, the cortaram, com ânimo duro". (Od. XXII, v. 475-477). Uma vez posta em 
movimento, não havia freios para a roda da vingança. Todas as dívidas deviam ser pagas.

Em meio ao banho de sangue do Canto XXII, contudo, um ocorrido chama a atenção: Fêmio, o aedo que acompanhava as farras no palácio, tem sua vida poupada. Agarra-se aos joelhos de Ulisses e lhe pede perdão, dizendo ter sido conduzido à força à companhia dos pretendentes. A versão parece ser verdadeira $\mathrm{e}$ Telêmaco a confirma ao pai. No entanto, esse episódio ressoa o estatuto especial dos aedos na Odisseia e, consequentemente, no mundo grego.

Fêmio reivindica sua condição de aedo para ser poupado da morte; colocase, por assim dizer, acima do alcance da violência. Não é apenas a benevolência de Ulisses que o salva, nem somente sua aparente inocência. No diálogo de Fêmio com Ulisses, o pedido de misericórdia é acompanhado de uma leve ameaça, que confirma o estatuto especial dos aedos: "Para ti próprio virá a desventura, se matares o aedo: eu mesmo, que canto para os deuses e para os homens". (Od. XXII, v.330).

Euricleia corre aos aposentos de Penélope e dá a notícia que Ulisses está no palácio e acabara de matar todos os pretendentes! Penélope supõe, aturdida, que os deuses haviam enlouquecido a fiel criada Euricleia. Entretanto, Euricleia insistia em narrar a Penélope todos os detalhes daquilo que somente ouvira de outros (pois as escravas encontravam-se encerradas numa sala próxima ao local da matança, por ordem de Ulisses) que contaram como se deu a matança dos pretendentes. A ardilosa Penélope até finge naquilo tudo acreditar, mas, por fim, resolve, então, deixar os seus aposentos, no intuito de confirmar, junto ao filho, os fatos revelados e relatados por Euricleia. Entretanto, Penélope foi duramente interpelada pelo indignado Telêmaco, pois a mãe continuava a duvidar da presença de seu pai no palácio.

Com efeito, a prudente, em segredo, nutre um plano: somente seu marido seria capaz de reconhecer certos sinais relativos à intimidade conjugal do casal. Interpelado por ela, Ulisses descreve os detalhes sobre a construção do leito conjugal, esculpido na raiz de uma oliveira (árvore símbolo da Grécia). A descrição narrada por ele era fidedigna e verdadeira!

Ambos se aconchegam no leito nupcial e aos prazeres do amor se entregam. Uma vez saciados tantos desejos, Ulisses narra, então, a Penélope, todas as aventuras e desventuras vividas durante o seu longo exílio de Ítaca. A última 
história foi sobre os cordiais Feácios... e, por fim, a ambos o sono agradável e relaxante lhes sobreveio.

Atená concede a Ulisses e Penélope uma noite de amor estendida para que os amantes pudessem desfrutar o momento. O nascimento do sol é retardado, para que eles possam passar mais tempo juntos. A Aurora de dedos róseos sai do Oceano, Ulisses desperta e demonstra o desejo de rever o pai, o velho herói Laertes.

O deus mensageiro do Olimpo, Hermes, conclamava as almas dos pretendentes, "convidando-as", desse modo, a entrar no Hades. O deus mensageiro guiava uma grande chusma de almas uivantes, todas em direção ao interior do Reino dos Mortos. Lá se encontravam as almas dos guerreiros argivos a dialogar e a se perguntarem de quem afinal se tratava tão grande número de almas que entrava pelo Hades a um só tempo.

Então, a alma do pretendente Anfímedonte narra, a todos, os acontecimentos que deram origem à história do reencontro entre o herói Ulisses e sua fiel Penélope. Anfímedonte resume, às sombras ouvintes, o "Nóstos" (o "Retorno" do herói) do divino Rei de Ítaca. Um início de revolta se alastra entre as sombras dos heróis gregos já mortos, porém, logo aplacada pela interferência e sensatez de Palas Atená.

Enquanto tais desdobramentos tinham lugar nas profundezas do Hades, Ulisses sai em busca do pai, Laertes, que, desgostoso pela ausência do filho, se encontrava em profundo estado de melancolia, em autoexílio numa fazenda distante de Ítaca.

Chegando ao local, ele se apresenta a Laertes; porém o pai não reconhece o amado filho. Ulisses. Laertes não crê na veracidade daquelas palavras. Ulisses deve passar ainda pela última prova: identificar as árvores frutíferas do pomar de Laertes. É a metáfora da genealogia, do pertencimento, da autenticidade. Diante de tais sinais, Laertes convence-se, finalmente, tratar-se realmente do seu filho tão amado. Ambos se abraçam e choram.

Enquanto isso, "Fama" - a rápida mensageira - espalha as recentes notícias por toda a ilha de Ítaca. Eupites, pai de Antínoo, corre até a Ágora, conclamando todos os cidadãos itacenses a erguerem-se contra o herói Ulisses, responsável pelas desgraças advindas à pátria desde o seu retorno. Contudo, do alto do Olimpo, Palas Atená implora a Zeus que cesse a guerra.

Assim, do Olimpo, por Zeus, Palas Atená, a deusa de olhos glaucos, é autorizada a atirar sua lança mortal contra Eupites: o infeliz tomba vencido. E firma- 
se o pacto de paz permanente que a donzela de Zeus poderoso, a de olhos glaucos, Palas Atená, firmou entre os grupos inimigos. Com a intervenção de Palas Atená o rebuliço e a revolta se aplacam e Ulisses entra em seu palácio e busca retomar seu lar agora reintegrado a seu proprietário, sua esposa e seu filho.

Embora a Odisseia seja uma narrativa repleta de monstros, deuses e lugares fantásticos, aquilo que realmente conquista o coração do leitor e mantém o interesse pela obra é o seu protagonista. Ao contrário, por exemplo, de Aquiles, seu valor não é provado no campo de batalha ou através da violência bruta. Assim, representa outro lado da cultura grega da época: a reflexão, a diplomacia, a retórica, o espírito inquisitivo e criador.

Sem poderes sobrenaturais ou qualidades físicas extraordinárias, ele sobrevive porque é esperto, tem a proteção dos deuses e está sempre disposto a inventar soluções para os problemas que encontra. A sua história é de superação: apesar de todas as adversidades, não se rende e luta até o final, perseguindo com métis seu objetivo, retornar a Ítaca!

Ao longo da obra, é impossível não nos solidarizarmos com Ulisses: admiramos a desenvoltura, o jeito como maneja as palavras e a habilidade com que lida com as situações. Entre o destino ditado pelos deuses e o livre-arbítrio dos personagens, a obra focaliza o sofrimento humano personificado em Ulisses.

$\mathrm{Na}$ versão original, em grego antigo, a palavra que inaugura a obra é "homem". Podemos mesmo afirmar que a virtude mais valorizada em Ulisses é a sua humanidade. Tanto que, mesmo quando Calipso lhe oferece a vida eterna, ele opta por continuar seu caminho de regresso e estar sujeito aos perigos do nóstos para envelhecer e morrer ao lado da família.

Ulisses representa, então, uma versão do ser humano que se tornou um modelo na cultura do Ocidente: aquele que falha, que tem defeitos, é derrotado inúmeras vezes, é testado aos seus limites extremos, mas sobrevive e prospera graças à sua inteligência e força de vontade!

O protagonista parte, a princípio, convocado para uma guerra. Perde-se num trajeto incessante. O mal do exílio, que esteriliza sentimentos, preenche Ulisses com o desencanto pelo mundo, um desencantamento saneado, na Odisseia de Homero, pelo lar, na casa e com a vida em família. 


\section{3 \\ A Odisseia Moderna de Nikos Kazantzákis}

"Life's a journey not a destination"

Ralph Waldo Emerson

A Odisseia de Kazantzákis, no diálogo que estabelece com a obra de Homero, se concretiza como uma expressão artística legítima do século XX, pois o autor busca uma visão crítica da arte, do mundo e do homem moderno; procura um caminho de recondução do homem, da arte e do mundo a seu verdadeiro lugar. Se lança em uma procura por virtudes perdidas, valores esquecidos e rastreia o novo lugar do ser em detrimento do ter. O que se registra na obra kazantzakiana é a existência de um narrador que vai contar uma história para ser lida e não mais para ser ouvida e cantada como o era o narrar homérico. Este é o resultado da mudança de contexto temporal em que as obras se situam: se antes o que mantinha viva a epopeia era a expectativa por um tipo de produção esplendorosa, inspirada e com alta qualidade técnica, o poiéo, "fazer poético", ação exclusiva do aedo. Nela se encontrava a memória da tradição oral; agora são seus ecos, reminiscências, em novas formalizações - é a intertextualidade que vigora.

Na obra de Kazantzákis a cronologia é marcada pelo avesso do tempo de Homero, o tempo é o senhor absoluto, mas a obra transcorre contra o tempo, que é confuso e o grande inimigo de Odisseu. Trata-se de um fator desorganizador do eu ficcional. O protagonista é desviado do modelo de heroi homérico. À medida que a obra nos é apresentada temos contato com a perspectiva de construção de um herói completamente diferente de seu antecessor, o antigo Ulisses e o moderno Odisseu, ilustrações emblemáticas de suas respctivas épocas de criação.

Se Ulisses fez um percurso em busca de abrigo, enquanto lutava pela volta ao lar, Odisseu procura a evasão, uma incessante peregrinação. Inclusive tem a iluminação de construir uma cidade ideal em seu caminho, em sua busca. É um representante da modernidade fracassada, é o retrato da autotrapaça de um sujeito que idealizava um mundo que o expulsou para uma guerra. O mal do exílio esteriliza o sentimento, gera um desencanto de mundo, cria um desencantamento do lar, com a casa e com a vida em família tornando Odisseu um outsider, já que 
foi transformado por todas as experiências que viveu. Não é nem de longe o mesmo que partiu. Volta completamente modificado, por isto não mais se adapta.

Apresento na sequência uma síntese comentada da Odisseia Moderna que ressalta as ocorrências mais significativas desta que é uma obra monumental.

\section{BREVE SÍNTESE DA ODISSEIA MODERNA de NIKOS KAZANTZAKIS}

\section{Prólogo - Sofrimentos do renomado Odisseu}

No prólogo em 73 versos, temos a invocação ao Sol e anúncio do tema: cantar as penas e tormentos do renomado Odisseu, que se põe em marcha outra vez, após a chacina dos pretendentes de Penélope. As viúvas, órfãos, pais, bem como os fantasmas (eídola) dos mortos em Troia incitam o povo a se insurgir contra o palácio de Odisseu. Em mais uma exibição de sua astúcia, o recém-chegado persuade o povo com promessas e ameaças, manobra a situação e a reverte a seu favor. Após fazer um reconhecimento de sua propriedade e de seus bens, dirige-se ao topo da montanha onde estão sepultados seus ancestrais para lhes oferecer sacrifícios e realizar o ritual dos mortos.

\section{Livro I Ulisses controla a revolta em Ítaca}

1305 versos

Ulisses em Ítaca. Reencontro com os familiares, estranhamento. Revolta da população.

Saudação aos mortos. Insatisfação do herói. Decide abandonar a ilha e começa a reunir companheiros para a partida: Capitão Clam, Hardihood, Centauro, Orfeu e Granito. No Outono começam a construção de uma embarcação. No verão, Nausícaa chega e são celebradas as núpcias com Telêmaco.

\section{Livro II Ulisses deixa Ítaca para sempre}

1493 versos

Narrativas de Ulisses à família sobre suas viagens. Desejo de partir. Construção de um novo barco e convite a novos companheiros. Morte de Laertes. Casamento de Telêmaco com Nausícaa. Partida de Odisseu. A narrativa de Ulisses de suas três aproximações da morte (Calipso, Circe e Nausícaa). Sente o desapontamento com o retorno a Ítaca, compreende que sua terra natal era a mais letal máscara da morte, uma prisão. Decide abandonar a ilha e inicia a reunir companheiros para a partida: 
Capitão Clam, Hardihood, Centauro, Orfeu e Granito. No Outono começam a construção da embarcação. No verão Nausícaa chega e são celebradas as núpcias com Telêmaco.

Alterando o roteiro traçado por Homero, é Ulisses, não Telêmaco, quem parte de Ítaca para Esparta, estando este já casado com Nausícaa, a princesa cretense. Exclui-se do roteiro de Ulisses a primeira parada em Pilos, para (Ulisses) fazer consultas a Nestor. Telêmaco traçou um trajeto que constituia um périplo (saída de um ponto e retorno a ele): Ítaca - Pilos - Esparta - Ítaca. Ulisses tinha um projeto em aberto: afastar-se de Ítaca, com duas escalas: Esparta e Creta.

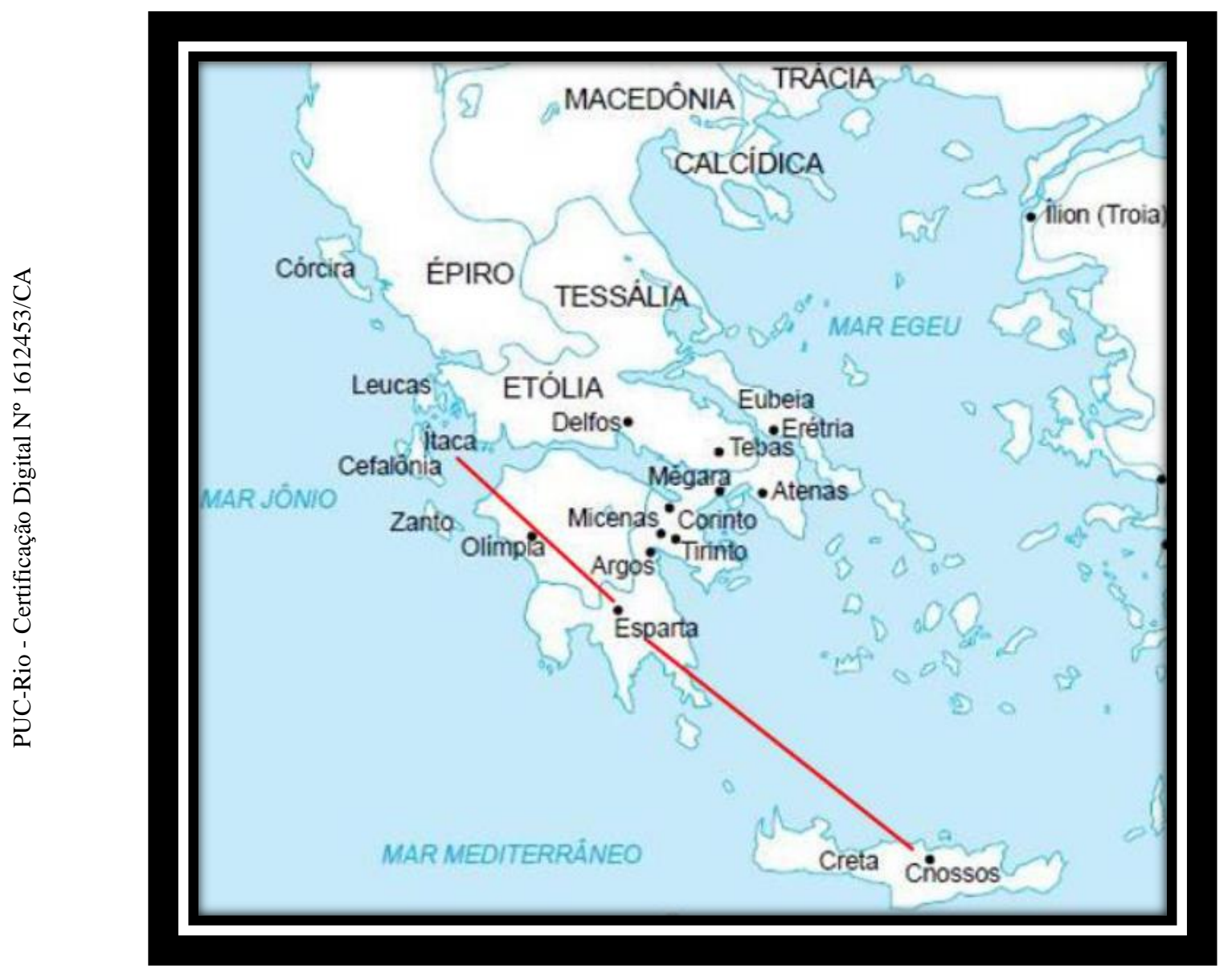

De Ítaca a Esparta e a Creta (Knossos).

\section{Livro III Ulisses vai para Esparta}

1463 versos

Navegação. Sonhos com Helena pedindo ajuda. Chegada a Esparta, onde socorre o decadente rei Menelau a sufocar uma revolta popular. Encontro de Ulisses com Helena. Orfeu canta fábula das minhocas macho e fêmea que conhecem 
profundamente os elementos geológicos, meteorológicos e todos os materiais da natureza. Ulisses sonha com Helena pedindo-lhe ajuda, em uma nova ameaça de rapto. Acordado, complementa a fábula: a minhoca descobre o ferro; enfrenta com sua espada a espada de cobre do deus que a ataca e o vence (matando-o). Centauro explica a nova concepção religiosa de Ulisses o novo deus é o metal, o ferro, que os bárbaros traziam consigo e com que breve destruiriam os velhos deuses e civilizações baseadas no bronze.

\section{Livro IV Segundo rapto de Helena}

1363 versos

Revolta de Ulisses contra a decadência de Menelau. Planejamento do rapto de Helena, com o consentimento desta. Última ceia entre os antigos companheiros de combate em Troia. Helena parte com Ulisses. Chegam ao Monte Taigetus onde Ulisses admira o pastor Rocky, que adere ao grupo. Menelau concede uma festa onde coroa os aristocratas e os filhos bastardos dos dórios. Na festa Ulisses se junta aos bastardos, demonstrando sua predileção pelos fora-da-lei. Menelau presenteia Ulisses com uma estátua de Zeus, símbolo da amizade. Ao amanhecer, Centauro, Rocky e Ulisses roubam uma carruagem e partem, levando Helena.

\section{Livro V Chegada a Creta}

1344 versos

Chegada à Creta. Orfeu lamenta-se de que Deus exija um sacrifício em expiação ao rapto de Helena.Ritual de regeneração da fertilidade na terra e no povo pelo rei Idomeneu no Monte Dicte. Orestes, Helena e Rocky seguem para Knossos, os demais ficam no porto reparando o navio. Na chegada ao palácio, Dictina, segunda filha do rei, sacerdotisa, não cumpre as regras da hospitalidade. Fida, filha mais velha do rei, tem um ataque epilético. Ao retornar ao palácio, Idomeneu é avisado que sua filha mais nova, a virgem Krino, fora capturada para ser a noiva incestuosa no ritual do touro. Idomeneu resolve assumir Helena como esposa ritual.

\section{Livro VI O ritual do touro em Knossos}

1292 versos

Odisseu entra em cena. Helena atua como sacerdotisa. Festividades do touro. Cena de homossexualidade de Krino. Dictina se une a Odisseu. Odisseu começa a 
planejar a conspiração contra o reino decadente. Os cinco parceiros pactuam com um ferreiro preso no labirinto o fornecimento de armas para os bárbaros. Fida é levada para as companheiras. Odisseu adormece com a morte a seu lado, sonhando com a vida.

\section{Livro VII Conspiração para destruir Knossos}

1362 versos

Odisseu e os companheiros colocam em prática a conspiração. Idomeneu pressente a emboscada. Helena casa-se com o rei. Odisseu medita, e Deus aparece a ele. A destruição se aproxima. A frota de bárbaros se aproxima dos portos. Conspiradores assumem suas posições e prepara-se o massacre.

\section{Livro VIII Destruição de Knossos}

1337 versos

O grupo toma o palácio e o incendeia. Knossos é reduzido a cinzas. Morrem Idomeneu e sua filha Fida. Morre Stridás, capitão do navio de Odisseu. Karterós, outro companheiro de Odisseu, ocupa o trono, casa-se com Helena e nela concebe um filho. Odisseu parte mais uma vez, levando Dictina, filha de Idomeneu. Chegam ao Egito e avistam o rio Nilo.

\section{Livro IX O império decadente dos egípcios}

\section{4 versos}

Odisseu abandona Dictina. Descoberta de um cemitério às margens do rio Nilo. Entrada nas catacumbas de faraós egípcios, saque de seus tesouros. Odisseu se arrepende e atira as riquezas no rio. Compaixão do povo faminto e miserável.

Odisseu deixa os companheiros e se isola para meditar. Tebas. Hierápolis (Hekmaton+Nefertite). Ulisses chega ao Egito para fazer a ascece, berço da espiritualidade humana. Chegar ao Nilo é um marcador geográfico importante no percurso de Odisseu.

\section{Livro X Rebelião no Egito}

1402 versos

Odisseu encontra Rala, uma revolucionária, e junta-se ao seu grupo que protesta diante das muralhas do faraó. Os líderes são presos, e Odisseu é ferido brutalmente 
na cabeça. No calabouço, o herói se recupera e descobre a imagem selvagem, faminta e terrível do novo deus. Petrakas e Rocal, companheiros do herói partem. O faraó liberta Odisseu e Rala. O herói reencontra os dois amigos que restaram: Orfós, o flautista, e Centauro. Presença dos assessores revolucionários: Scarab (desconfiado com a terra); Nilo (inteligente como a Lua); Hawkuje (incansável como o fogo). Os dórios já estão em terra, devastando tudo. Rala deseja suicidarse, por pensar que Odisseu traíra sua casa.

\section{Livro XI Revolução: derrota no Egito}

1359 versos

O Faraó tem terríveis pesadelos. Rocal retorna ao grupo. O grupo formado por Ulisses e companheiros mais os revolucionários do país se põem em guerra contra o faraó. Todos são abatidos, morrem os principais líderes da revolução. Na prisão, Ulisses esculpe três máscaras de deus. Ulisses é convocado à sala do trono para esconjurar o mau sonho do faraó. Inicia uma dança selvagem e apresenta a máscara selvagem e monstruosa de seu deus. O faraó, aterrorizado, o liberta, juntamente com os companheiros. Nilo opta por ficar fomentando a rebelião.

\section{Livro XII Fuga do Egito - Marcha no deserto}

1337 versos

Êxodo pelo deserto africano. Ulisses lidera a massa de desesperados, indivíduos à margem da sociedade. A travessia é de intensas privações e sofrimento. Promete ao povo a construção de uma cidade ideal. Persiste o leitmotiv ${ }^{18}$ : Odisseu conjura seus seguidores a se submeterem a um impiedoso deus da sede, fome e guerra. São tantas as dificuldades, que Ulisses ordena que fiquem para trás os que não possam acompanhar. Centauro se apieda dos velhos e das crianças que ele guia, e se afasta de Ulisses. Encontram uma cidade de negros obesos. Ulisses filosofa para suas tropas: todas as aventuras e experiências levam a maiores revelações de Deus.

\footnotetext{
${ }^{18}$ Há aqui uma certa analogia com o êxodo do povo judeu, que sai do Egito e atravessa o deserto, em busca da sua libertação total, com a fundação de uma cidade onde viver com liberdade.

MÚSICA.tema melódico ou harmônico destinado a caracterizar um personagem, uma situação, um estado de espírito e que, na forma original ou por meio de transformações desta, acompanha os seus múltiplos reaparecimentos ao longo de uma obra, esp. em óperas; motivo condutor.

POR ANALOGIA ideia, fórmula que reaparece de modo constante em obra literária, discurso publicitário ou político, com valor simbólico e para expressar uma preocupação dominante. Definições de Oxford Languages.
} 
Conta a Granito sua visão de uma cidade baseada na nova visão de Deus: a Centauro, que cidades podem ser criadas fora desta concepção.

\section{Livro XIII Através da África escura até a foz/nascente do Nilo} 1400 versos

Passagem por aldeias de negros. Perda definitiva de um companheiro, Orfós, e reencontro de outro, Pétrakas. Chegada ao delta do Nilo, onde os seguidores armam acampamento. Odisseu se isola em retiro no alto da montanha por sete noites. Reencontro com Orfeu, Centauro, Granito e Rocky.

\section{Livro XIV Odisseu comunga com Deus - Ascética}

1410 versos

Ulisses alcança a etapa metafísica, passagem que se confunde com a obra Ascese os Salvadores de Deus (1927). Em meditação por sete dias, o herói vislumbra as etapas de elevação da ascese kazantzakiana e alcança a compreensão de "deus". Retorna ao convívio da massa, certo da construção da Cidade Ideal. Odisseu se vê como protótipo da humanidade: homem das cavernas. Héracles (o Hércules latino) exorta Odisseu a cumprir o $13^{\circ}$ trabalho, que ele não sabe exatamente qual seja. Desfile de ancestrais: Leviatã, Bugio etc. Parte para a construção da cidade ideal.

\section{Livro XV Constroem a Cidade Ideal: utopia}

1460 versos

Após uma longa peregrinação pelo deserto, o herói se dispõe a criar uma cidade ideal, mais justa igualitária, onde a multidão de homens que o seguiam alcance e supere seu destino humano. No mesmo dia de sua inauguraçãoa grande obra será destruída por um terremoto e o herói retomará seu percurso solitário. $\mathrm{Na}$ configuração da sociedade utópica fracassada que propõe Kazantzákis toma em parte modelos das cidades ideais de Platão e de Thomas Morus que influenciam de maneira decisiva o pensamento nietzschiano, o contexto sociocultural e as circunstâncias históricas do século XX. A Cidade Ideal é construída para abrigar o novo deus. Istantaneamente surgem novas leis para governar o mundo. Festividade de inauguração. Ocorrem imprevistos desastrosos. Ulisses pragueja. Rocky chega montado num elefante branco, para colocar-se à disposição de Ulisses perante os perigos que se anunciam. 


\section{Livro XVI - Destruição da cidade}

1394 versos

Erupção do vulcão que assola toda a cidade, morte dos últimos companheiros. Ulisses fica em completa solidão. Passagem trágica. Ulisses se desvencilha das últimas ilusões.

\section{Livro XVII - A plena liberdade}

1351 versos

Ulisses assume o completo ascetismo, para além de todas as ilusões. Com uma flauta, começa a criar vidas humanas que dialogam como em um teatro. O herói reconcilia-se com a terra, a existência e as forças de criação e destruição.

\section{Livro XVIII - Rapsódia do príncipe e da prostituta}

1445 versos

Começam os encontros com personagens da história mundial. O primeiro é um príncipe atormentado pela miséria do mundo, sem encontrar a razão de sua existência. Em seguida aparece uma prostituta.

\section{Livro XIX - Rapsódia do eremita e do Capitão Elias}

1439 versos

Encontra o Eremita cego que morre com a mão aberta, com sede de vida e o Capitão Elias que vive de tocar a harpa, ampla significação do canto como criação.

\section{Livro XX - Rapsódia de Dom Quixote}

1319 versos

Encontro com um cavaleiro louco, representação de Dom Quixote. Ulisses torna-se renomado como asceta, sua fama atravessa os vilarejos e todos querem se aconselhar com ele. Encontro com o Hedonista e, em seguida, com homens primitivos.

\section{Livro XXI - Rapsódia de Jesus}

1440 versos 
Movimento de descida ao sul da África, começo da morte do herói, que vai arrastando tudo consigo pela memória. Em uma das cidades descobre que se tornou um deus venerado em Creta. Começa a construir sua última embarcação, em forma de ataúde. Encontro com um pescador muito jovem que lhe apresenta a ideia da recompensa após a morte, representação de Jesus. Comove-se com a bondade do jovem, mas não aceita sua doutrina. Embarca no ataúde e se dirige para as terras geladas, preparado para a morte.

\section{Livro XXII - A aldeia polar}

\section{6 versos}

Tempo e espaço se fundem. Ulisses navega solitariamente em alto-mar, em direção ao Pólo Sul. Após o rompimento da quilha do barco, encontra uma aldeia nas neves. Vive algum tempo com esta população, cujo único objetivo é saciar a fome. Com a chegada da primavera, os habitantes da aldeia se preparam para mudar-se de aldeia. Todos peregrinam com alegria, Ulisses à frente toma seu próprio caminho em direção ao imenso oceano gelado. A camada de gelo se rompe, e a população inteira é tragada pelo mar.

\section{Livro XXIII - A última navegação}

1315 versos

O herói vê-se nas várias etapas da vida. Sente que venceu a morte, pois esvaziou seu corpo e tornou-se espírito. Despede-se dos cinco elementos da natureza. Entrega-se serenamente à morte. A embarcação colide com um iceberg. Ulises agarra-se ao monte de gelo, completamente desarmado, ferido, enquanto gaivotas o bicam. Encontra-se já sem forças para conclamar os amigos mortos.

\section{Livro XXIV - Desmaterialização}

1418 versos

De todas as partes do mundo, os amigos mortos acorrem em cortejo fúnebre, amparando Odisseu em sua última travessia. A multidão se agarra ao iceberg ao lado de Ulisses: os companheiros de navegação, Helena (que já havia morrido), o Eremita, o príncipe angustiado que se tornou a representação de Buda, Rala, o cão Argos como único representante de Ítaca. Ulisses levanta os olhos e vê os três antepassados: Hércules, Prometeu e Tântalo. À proa, Orfós canta sua última canção. 
O heroi se entrega à morte com um sorriso. A mente apaga-se e tudo ao seu redor torna-se névoa. No epílogo, o sol lamenta a morte de seu amado.

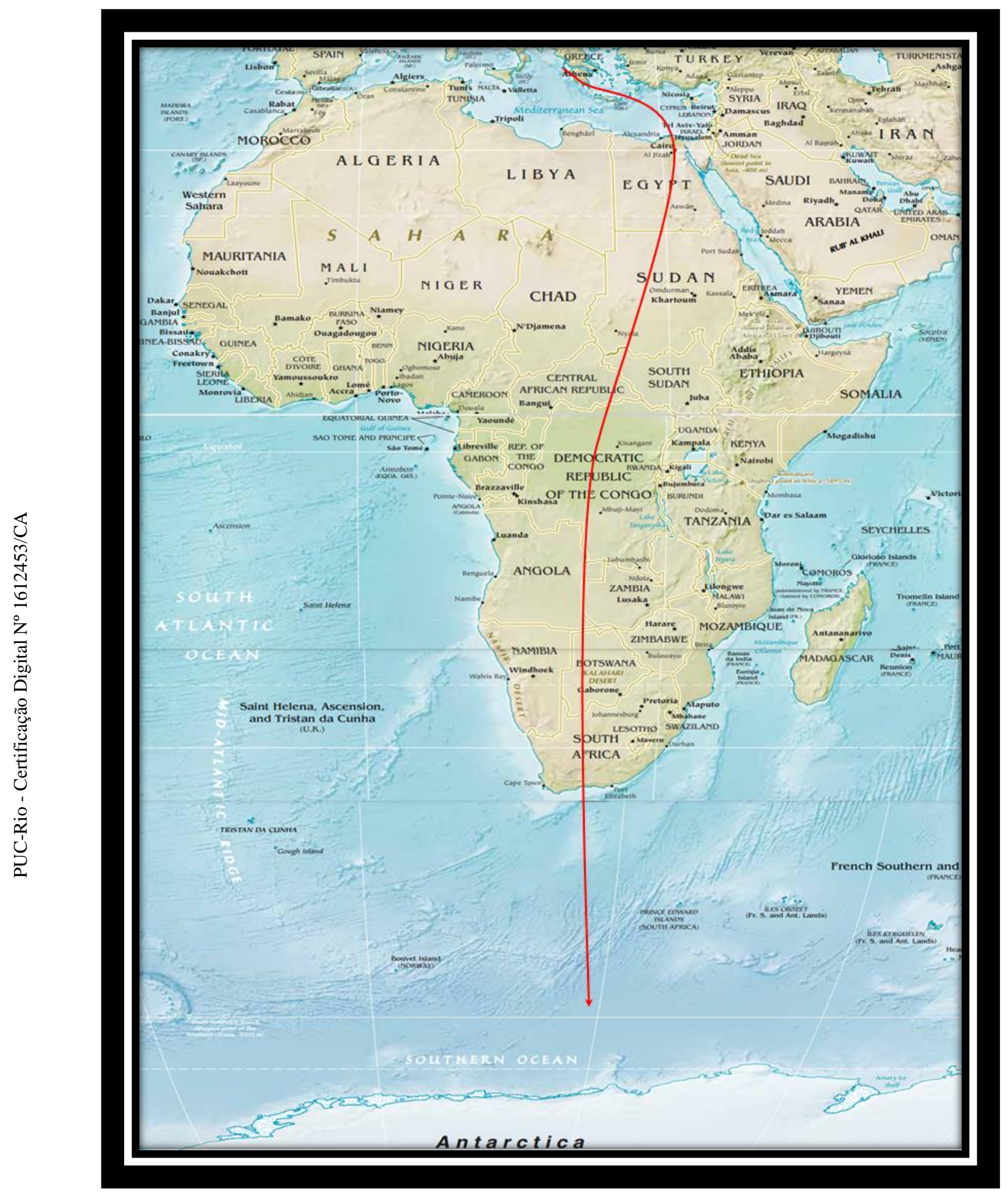

Percurso de Ulisses até o Oceano Antártico 
A edição inglesa (1958) da Odisseia de Kazantzákis, assinada por Kimon Friar, vem acrescida do subtítulo "uma continuação moderna" (a modern sequel), diferentemente do original grego e das traduções espanhola e francesa que a obra recebeu. A inserção não poderia passar despercebida e nos leva imediatamente ao contexto de eleição de tal título. Na introdução da obra, Friar não justifica objetivamente o acréscimo, porém é possível supor, por meio de elementos fornecidos pela obra, suas possíveis razões.

Kazantzákis produz sua obra em demótico e foi um defensor ativo da língua como uma afirmação da identidade grega e comumente dizia "a língua demótica é nossa pátria", e foi nesta língua que a maior parte de sua produção literária de popularizou e seus versos são decaheptassilabos. Quando foi presidente da "Sociedad Solomos" escreveu um manifesto em que expunha os argumentos em favor do uso escrto da língua. A estrutura formal da obra de Kazantzákis denota, evidentemente, o modelo clássico, favorecendo o estabelecimento de vínculo direto com a obra homérica de origem e, consequentemente, incidindo na apreciação de Friar. Numa análise apressada, a constatação de anacronismo se justifica; entretanto, não haveria necessidade de leitura, se a disposição formal fosse suficiente para classificar uma obra. Seguindo na posição oposta, é intrigante notar que Kazantzákis não inicia sua obra a partir do último canto do poema de Homero, ou seja, a partir do final, mas introduz sua escrita no andamento da escrita do antecessor, configurando novo enredo para a renomada Odisseia. Essa atitude revela que Kazantzákis acolhe a configuração homérica até o verso 477 do canto 22, mas opõe-se aos dois últimos cantos, como se rasgasse suas páginas ou apagasse sua inscrição. Tal conduta não está livre, certamente, de ser considerada uma grandiosa ousadia, pois o autor intromete-se na textualidade homérica, renegando o desfecho do poema inaugural e o próprio mestre do ocidente, para assumir a função do grande bardo que canta as penas e tormentos do renomado Ulisses.

Se a continuação constitui marca de prolongamento ou complementação de traços iniciais de sua antecessora, a obra herdeira, de certo modo, estaria em concordância com a obra que lhe deu origem. O termo "continuação" empregado por Kimon Friar ${ }^{19}$ não revela ruptura, nem tampouco "desafia o mais sacrossanto

\footnotetext{
${ }^{19}$ FRIAR: 1958, p. IX. Na verdade, Friar entra em contradição, ao afirmar que Kazantzakis ousa desafiar Homero. Como a continuação não representa ruptura, a Odisseia de Kazantzakis não seria, assim, um desafio aos pressupostos da obra homérica
} 
de todos os poetas". Não nos parece apropriada, portanto, a avaliação da Odisseia kazantzakiana como continuadora da tradição homérica, pois, a partir do ato rebelde de apagar (ou rasgar) e imiscuir-se no texto de origem, o poema moderno estabelece nova rede de significações, ainda que o diálogo com o passado esteja presente, estrutural ou tematicamente. ${ }^{20}$ Esta nova rede de significações é o que deveremos investigar, sinalizando as tensões que o poema de Kazantzákis estabelece entre tradição e modernidade.

Em termos mais específicos, esse exagero se manifesta na conformação épica peculiar à produção de Kazantzákis, obra que extravasa as medidas da "legalidade estética". Os excessos se manifestam no plano estrutural - 33.333 versos, múltiplos epítetos para os personagens - e no plano temático - Ulisses percorre um caminho desmesurado, de Ítaca ao polo sul, encontra personagens variados (representantes das diversas épocas da história humana), derruba crenças da antiga Grécia , atravessa o inclemente deserto liderando uma grande massa, funda uma nova cidade, desafia a Deus e à natureza, torna-se um famoso asceta, alcança os confins do mundo, onde homem algum jamais teria chegado e morre de maneira também grandiosa, agarrado a um iceberg no imenso oceano e diante de um numeroso público de mortos. Percebe-se, portanto, que a Odisseia não é desmesurada apenas em seu aspecto estrutural, mas inclusive se instaura pela amplitude temática e geográfica.

A Odisseia começa e termina com a presença do Sol (no Epílogo o astro deixa de ser uma figura invocada para tornar-se uma personificação que lamenta a morte de Ulisses). Inaugurando e encerrando a epopeia, o Sol representa o companheiro onipresente de Ulisses, o único que presencia completamente seu itinerário, seja como algoz na travessia do deserto, seja como única testemunha da batalha final nos gelos antárticos. Miguel Castillo Didier assinala as variadas formas pelas quais o sol se manifesta no poema:

É um grande senhor oriental que passa, elegante e orgulhoso. É um deus que ergue seus chifres sobre o horizonte e, apartando as nuvens, deixa ver, pouco a pouco,

\footnotetext{
${ }^{20}$ Deve ficar claro que o aproveitamento dos temas clássicos na Odisseia kazantzakiana não se restringe à relação por diferenciação entre as duas obras, mas propicia, inclusive, um procedimento de análiseEm outras palavras, parece-nos pouco proveitosa uma separação entre os estudos clássicos e modernos, pois muitas das reflexões teóricas antigas e das significações das histórias míticas carregam questões extremamente modernas que podem colaborar no processo de análise literária, juntamente com as correntes mais recentes.
} 
sua testa, seus olhos, sua boca. É um imortal cujos raios - mãos de cinco dedos estendidos - acariciam o mundo e revivem os mortos. É um arqueiro belicoso. É uma criança de boina de ouro e malha de bruma celeste, que brinca entre as mãos da Mãe Noite. É um disco de ígneos olhos que fazem correr pelo céu o ontem e o amanhã. É um palácio dourado cujas duas portas abrem ao ocidente e ao oriente. É cada uma das aves, desde as mais ternas até as mais ferozes. É um dócil falcão, sujeito com cordões áureos, que solta ao céu um falcoeiro misterioso. Também toma as figuras de diversos animais: um lebréu vermelho; um ágil leopardo que cai sobre os bosques e pradarias; um touro novo que ressona, furioso, quando o arrastam ao poente, ao sacrifício. No penúltimo canto, é uma trindade: o pai fecundo, a fértil mãe que alimenta o mundo com seus peitos, e o filho que dança e pula sobre as ervas e as águas da terra. (DIDIER, 2006-2007, p. 217-218)

Trata-se, como o poema de Homero, de uma epopeia dividida em 24 cantos, tendo como personagem central e herói Ulisses; Ítaca é cenário para o primeiro e o segundo cantos. Ulisses parece dar continuidade às ações registradas por Homero, já que o poema moderno se inicia após a matança dos Pretendentes (retomando o canto XXIII, no verso 477 da obra fundadora). O poema moderno estabelece uma nova rede de significados e mantém uma conexão com a obra antecessora em forma de diálogo seja com o tema ou com a estrutura. A epopeia de Kazantzákis mantém temas como as viagens e o percurso do herói, mas não em tom de conformidade com sua antecessora e sim em contraposição à mesma, operando a atualização dos valores que passam a mover o herói da modernidade.

Os pontos de contato são poucos, pois a obra herdeira se desvia na quase totalidade da homérica e é nesta nova rede de diferenças que observamos uma espécie de tensão entre a tradição e a modernidade, foco este que não é determinante para a análise pretendida aqui e não será objeto de estudo neste recorte. O propósito é avaliar o percurso dos heróis homônimos nas duas obras, que desenvolvem trajetórias díspares, até porque estão ambos acomodados em épocas extremamente distantes, em contextos históricos diversos e possuem objetivos opostos. Apesar da desproporção de metas dos heróis nas referidas obras o que vale salientar e ressaltar é a permanência dessa figura emblemática como influência e elemento inspirador na literatura através dos tempos.

O Ulisses de Kazantzákis tem em sua jornada encontros, na esfera humana, com personalidades da história e da mitologia, mas também com pessoas do cotidiano -- presentes no noticiário do século XX, --com que cruzava no seu caminho, diferente do personagem homérico que estava em outro patamar e dialogava com reis, seres híbridos e deuses. O Ulisses de Homero navegou a 
contragosto para Troia e empreendeu a volta para Ítaca com gosto, persistência e tenacidade, apesar da longa e tumultuada rota de retorno.

O protagonista da epopeia moderna não pode ser aquele que, ajudado pela divindade e dono de qualidades excepcionais, faz situações de conflito reverterem em momentos de equilíbrio. Numa evidência de que as propostas utópicas não têm mais lugar no século XX, o leitor do poema de Kazantzákis depara-se com as dúvidas e questionamentos da contemporaneidade.

Podemos detectar no Ulisses homérico uma forte ligação com a natureza. Ele utiliza o conhecimento dos fenômenos naturais a seu favor em suas viagens e batalhas, ou seja, sabe a hora certa para zarpar de algum porto com sua frota e companheiros, guiado pelo nascimento do sol assim como o momento de baixar as velas e ter uma noite de calmaria no mar após o entardecer. Possui também uma forte ligação com os deuses que o protegem e o observam, vigiando sempre que possível e auxiliando-o a se libertar de perigos e fenômenos da natureza como vendavais, ondas gigantescas e seres extraordinários. Prontos a interceder a seu favor e recolocá-lo em sua trilha de volta ao lar.

Já o herói de Kazantzákis trava batalhas em outra esfera, não luta só contra inimigos visíveis e palpáveis, nem enfrenta seres mitológicos com poderes sobrenaturais da mesma forma que não tem seu caminho de peregrinação ligado às rotas marítimas (habituais na antiguidade). Quando se põe em marcha novamente após abandonar Ítaca, seu percurso é todo feito em uma caminhada sem itinerário definido, mas que o leva, depois de muitas peripécias, ao extremo da terra, a um lugar inóspito, o Pólo Sul. Podemos apontar, nessa última viagem, uma analogia do seu caminhar espiritual à procura do desconhecido, do insólito com o deslocamento geográfico dirigido ao limite do planeta, à fronteira com o inexplorado. Esses movimentos que acontecem em paralelo possuem uma simbologia, ou seja, observando o protagonista da saga moderna, que percorre um deslocamento geográfico equivalente a uma trajetória descendente, podemos fazer uma analogia com a descida do Ulisses de Homero ao Hades, episódio integrante do Canto XI da Odisseia homérica, quando este chega às portas, ao umbral da terra, guiado pelas instruções de Circe. Nesse ponto-limite, recita as fórmulas mágicas e as almas vêm até ele no mundo dos vivos; desta forma Ulisses vive uma experiência metafísica irrepetível que o modifica, pois não esteve no inferno e, ainda assim, teve a possibilidade de falar com as almas. O episódio é o equivalente à evocação, quando 
as almas atendem ao chamado de quem está no mundo dos vivos. Assim se marca a excepcionalidade do protagonista antigo, em contraste com o protagonista moderno, vivente de um tempo desencantado, onde os homens têm de enfrentar sozinhos suas dúvidas e anseios.

Por um lado, o que move o herói homérico é a busca por um rumo certo no retorno a Ítaca e, para ter sucesso em seu intento, ele procura se cercar de companheiros experientes e marinheiros corajosos que lhe seriam úteis nesta valente travessia. Está empenhado em cumprir seu objetivo primordial de encontrar sua terra natal, para isso ele realmente precisava de homens bravos e tenazes. Por outro lado e em contraste explícito, o herói kazantzakiano, ao iniciar sua jornada de autoconhecimento e busca, acaba se cercando de uma massa de desvalidos e esquecidos pela sociedade (mulheres, inválidos, crianças bastardas, piratas, ladrões, ciganas, grávidas, amantes) que o elegem como uma espécie de líder espiritual, mesmo que o próprio não se reconheça como tal. Mesmo que exacerbado, o comportamento do protagonista demonstra sintonia com as exigências da modernidade, onde a distância entre os planos religioso e prático e as crescentes desigualdades socioeconômicas obrigam os homens a concentrar-se em suas demandas pessoais.

Nos episódios seguintes, o séquito de desfavorecidos será a massa que o ajudará na tarefa de construção da Cidade Ideal após cruzarem o causticante e tórrido deserto africano, símbolo da fome e da sede, quando projetavam erguer um lugar onde todos teriam direitos e oportunidades iguais na terra da liberdade. No comando, Ulisses ordena aos desvalidos que montem o acampamento e iniciem os preparativos da construção enquanto ele irá para um período de sete dias de isolamento e meditação na montanha e, ao voltar, acredita estar com seu espírito maduro e apto para liderar a administração dentro dos altos muros de da cidade projetada e das leis guardiãs que irão ser redigidas ali.

Sendo considerado o construtor de uma cidade utópica, ao edificar muralhas em terras estrangeiras, o Ulisses de Kazantzákis tem uma conduta diversa da do herói em Troia já que este destrói as muralhas da cidade por sua astúcia ao se utilizar do estratagema lendário do episódio do Cavalo de Madeira cheio de soldados em seu interior, donde se originou a conhecida expressão "presente de Grego".

Nos encontros que teve com personagens ao longo de seu caminho, a liberdade conquistada pelo herói se mostra vigorosa, pois recusa ser envolvido nas 
utopias apresentadas por eles: o idealismo estapafúrdio do Capitão Uno (alusão direta a Dom Quixote), a insaciabilidade pelo conhecimento do velho eremita que falece de mãos abertas implorando sentido aos céus, a ideia da vida eterna em uma espécie de céu ou paraíso prometido que o pescador negro o faz conhecer. Escapando de todas essas possíveis influências, ele segue firme com suas próprias convicções. Viver com a consciência da brevidade das coisas e, ainda assim, conviver diariamente com o fim inevitável capacita ao herói não ser pego de surpresa pelo destino; o Ulisses kazantzakiano não foge da morte, não procura se agarrar à vida como um atormentado, e muito menos se enfurece com as injustiças da vida, julgando-as incoerentes; a morte não precisa buscá-lo, o próprio herói se eleva sobre a fatalidade e aceita o destino trágico. O movimento de descenso se realiza em paralelo ao deslocamento geográfico, pois Ulisses almeja alcançar o polo sul, aonde jamais homem algum teria estado, conquistando, assim, limites extremos e inexplorados.

A trágica e assustadora morte de Ulisses, segurando-se obcecadamente no iceberg, desarmado, vulnerável, enrijecido pelo gelo e ferido, nos limites do oceano gelado, consolida o caminho e a busca espiritual do herói cretense kazantzakiano.

Junto a Ulisses no iceberg estão os vultos dos companheiros de viagem e de luta, ilustrando uma espécie de cortejo fúnebre que o reverencia até sua mente desvanecer.

Como pode ser delineado o caminhar do novo Ulisses de Kazantzákis? Ulisses, em original viagem, empreende um reencontro frustrado, numa Modernidade fracassada, numa autossabotagem? O Ulisses moderno é sujeito que contempla um mundo, mundo este que o obrigou a ir para uma guerra. E em seu retorno impôs-lhe desafios mitológicos, numa errância de dez anos, entre expulsões, detenções e retenções, até o retorno a uma terra que ele já não reconhece como sua.

O sentimento do desterrado tem danos colaterais: abalo à sensação de pertencimento, sensação adquirida de permanente refugiado. O mal do exílio esteriliza o sentir, caotiza o cotidiano, introjeta desencanto de mundo, desajuste com o lar, com a casa, com cotidiano da vida em família.

Ulisses homérico faz todo um longo e turbulento percurso em busca de abrigo, enquanto Ulisses de Kazantzákis busca a evasão.

Nas palavras de Kazantzákis, a sua Odisseia é um rio que flui rumo ao futuro, mas um futuro de um mundo desencantado, sem charme, em que nosso herói 
passou a ter outro objeto de desejo. O exílio o desenraizou, portanto Ulisses não se enquadra, não se encaixa no seu antigo lugar. Ulisses vai caminhando para o Sul, um homem do mar que se dirige ao gelo, não quer sentir a terra sob seus pés, é um antigrego.

Para corroborar a adaptabilidade e a ressignificação de nosso personagem heroico, lembramos o retrospecto histórico que W. B. Stanford faz de Ulisses:

Para Pessoa, Ulisses é uma arkhé da realidade na ficção, um início no mito e na poesia, que expressa veladamente a esperança no iminente renascimento da vida e da cultura. Semelhante ao seu Ulisses é o Ulisses dos poetas gregos, que reencontram no herói homérico as raízes da própria história pessoal e nacional. Em "Ítaca" (1911), Kaváfis celebra a ilha, pobre e nua como um símbolo da própria vida que resplandece no fim de uma longa viagem - uma viagem que o homem deve cumprir sem pressa, aprendendo dos sábios que encontrará no caminho e enriquecendo pouco a pouco nos empórios fenícios ou entre os perfumes inebriantes das cidades egípcias. Em Sobre um Verso Estrangeiro (1932), Seféris canta, com a voz de DuBellay, "Feliz quem fez a viagem de Ulisses". O herói apresenta-se diante dele como um fantasma gigantesco, que "murmura entre a barba embranquecida palavras/ da nossa língua, como já falavam/ três mil anos atrás". Ele é um pai que ensina ao filho como construir um cavalo de madeira para conquistar a sua Troia: que conta "a árdua angústia de sentir as velas da nau/ inchadas pela memória e a alma tornar-se timão", que doa com suas mãos sapientes "o mar sem ondas, azul/ no coração do inverno" - Ulisses, no princípio, mestre da verdade e da vida. Na longa Odisseia de Nikos Kazantzákis (1938), o nosso herói, que partiu mais uma vez de Ítaca, experimenta o Todo: constrói uma cidade utópica no deserto, torna-se adepto de conhecimentos esotéricos, vira eremita em busca do ser, morre num iceberg na Antártida. (STANFORD, 1959, p. 222).

Com esta ilustração do autor supracitado, para o nosso personagem e herói detectamos, mais uma vez, a extensa trajetória de sua presença na literatura e percebemos que Ulisses se tornou um signo de contradição que cada cultura é chamada a interpretar a seu modo. 


\section{4}

\section{O exílio como tema literário}

"Tristes são os versos do exilado"

Ovídio

Aqui se encontra uma seleção de poemas que se notabilizaram pela temática do exílio. A partir destas páginas podemos sentir o eco de uma ontologia exílica e do desterro. São páginas antológicas que mergulham na problemática da perda de identidade, da renúncia inopinada aos direitos civis, ao abandono da identidade cultural, no martírio do isolamento. É um pout-pourri de poemas para apresentar a dor do exílio ou a busca de liberdade através do auto-exílio.

Através das manifestações em cada poema, podemos ter uma visão caleidoscópica de muitos Ulisses e outra, antecipatória, de outras versões que se espatifam em um caleidoscópio, transformando-se em fragmentos. Tanto uns quanto os outros deixando abertas múltiplas possibilidades de adaptações e releituras futuras.

Os poemas que se seguem não estão aqui apenas como ilustração da sobrevivência e do vigor do personagem tradicional, mas sim para registrar o direito a ter raízes, dar continuidade ao desejo de viver em um lugar que é seu, ou pelo menos já o foi. A manutenção da temática do exílio, do sentimento exílico, a extirpação forçada do lugar de origem, a expulsão de um território que fornece referências identitárias, que confere a bases para a existencialidade, a língua, uma memória até olfativa da terra de origem (os cheiros do "lar"), referências geográficas (as geograficidades de Eric Dardel ${ }^{21}$ e tantos outros).

Uma obra literária pode ser tão autêntica quanto a realidade já que nela se inspira. E é neste limiar ficção/realidade que se instauram as mais originais obras, é nestes lugares insólitos, nestes entrelugares onde o exilado se encontra que vivem a sensação de estar "in bitween", de participar de dois mundos num lugar de

\footnotetext{
${ }^{21}$ Geógrafo cultural francês que cunhou o termo (DARDEL, Éric [1952]. O Homem e a Terra: natureza da realidade geográfica. São Paulo: Perspectiva, 2011) para definir os espaços depositários de sentidos afetivos; o que o espaço contém, mas só se resgata através da subjetividade. Assim como a literariedade remete ao intraduzível da literatura, as geograficidades remetem ao sentimento de pertencimento aos lugares; enfim, à ontologia do espaço (BACHELARD, G. A Poética do espaço. In Os Pensadores. Rio de Janeiro: Abril cultural, 1978), ao sense of place de Pocock ("Haworth: A sense of literary place". In: MALLORY, W. E., SIMPSON-HOUSLEY, P. Geography and Literature: A Meeting of the Disciplines. E.U.A.: Siracuse University Press, 1988. Pp. 135-144).
} 
desestabilização em espaços heterotópicos e que os faz perder as características topológicas, os sujeitos que aí transitam renunciam as suas aptidões mais viscerais. O exílio nos compele estranhamente a pensar sobre ele, mas deve ser terrível de experienciar. É uma espécie de fratura sem cura entre uma pessoa e seu local de nascimento, entre o ser e seu lar, sua casa. E muito embora seja verdade que a literatura e a história contenham façanhas heroicas de românticos gloriosos que triunfaram longe de seu país, não são mais do que esforços para tentar superar a dor mutiladora do rompimento. Nada do que se realize no exílio tem o mesmo sabor do que aquilo que foi abandonado.

Para compor esta antologia optei por me valer das traduções em espanhol do Professor Miguel Castillo Didier, helenista, tradutor, acadêmico e musicólogo chileno, a quem tive a oportunidade de conhecer em visita a Santiago em 2012, é diretor do Centro de Estudos Gregos, Bizantinos e Neo Helênicos da Universidade do Chile. Desde então foi estabelecida uma intensa disponibilização de materiais, traduções e versões da obra de Kazantzákis por parte do professor Miguel que muito agregou a minha pesquisa e ao trabalho de escita da tese. Portanto, quis prestigiar a tradução dele por pensar que eram mais condizentes com o périplo linguístico por mim percorrido em busca de fontes.

\section{PEQUENA E SELETA ANTOLOGIA POÉTICA DO EXÍLIO}

Apenas para homenagear um escritor brasileiro inicio esta antologia com uma obra emblemática da literatura nacional, A Canção do Exílio que é um poema romântico (da primeira fase do romantismo) do escritor brasileiro Gonçalves Dias (18231864). A composição foi criada em julho de 1843 e ressalta o saudosismo em relação à terra natal. Se encontra ambientada aqui como ilustração de que os brasileiros também já experimentaram o "gosto" do exílio, seja ele voluntário ou político, em algum momento.

Gonçalves Dias compôs os versos abaixo quando estava em Portugal, estudando Direito na Universidade de Coimbra. Era relativamente frequente que filhos de famílias abastadas brasileiras cruzassem o oceano Atlântico para se formarem em faculdades portuguesas.

Tratou-se, portanto, de um exílio voluntário, ao contrário do que pode parecer com a leitura do título do poema. Mas, ainda assim, também sofrido e doloroso, a seu modo e evidencia esse tom de NOSTALGIA característico de quem está há algum 
tempo distante do seu país de origem. A "nostalgia" no caso deste poema, mais do que um traço biográfico, compõe a persona romântica do poeta.

Os versos se estruturam com uma clara oposição entre o aqui e o lá — o que há no Brasil e o que não se encontra fora dele.

Convém sublinhar que o Brasil havia declarado a Independência recentemente (em 1822) após um longo processo de tentativas de se desvincular do colonizador (desde 1800 se sentia esse impulso de liberdade).

Após finalmente terem conseguido a tão ansiada independência, os românticos sentiram a necessidade de trabalhar para a construção de uma identidade nacional. A tônica do poema é a presença da natureza como marca identitária. Na intuição fundamental da lírica do exílio há uma oposição adverbial entre o lá e o cá (o Brasil é sempre o lá), entre o não estar de todo e o estar ausente. O estar distante para compreender o que está próximo. A experiência básica do cá e lá, a terra onde se está não é aquela em que se gostaria de estar, a enunciação é sempre sobre o que está distante a partir do cá.

O cá e o lá se reproduzem ao longo do poema, traduzindo o sentimento de distância necessidade do nóstos para vencer o tempo necessário para cumprir sua agenda e o nóstos necessário para recuperar o sentido verdadeiro de sua vida, ligado aos sentidos do poeta - a visão (da paisagem brasileira), a audição (do canto dos pássaros), os cheiros da terra natal, o paladar das frutas. O exílio é um motivador particular para a poesia romântica, que encontra na saudade a expressão mais lata que o spleen inglês, a nostalgie francesa, a Sehensucht germânica... A saudade, herança mais especificamente lusitana do que genericamente ibérica, é um mal que ultrapassa a melancolia "spleeniana"; a "nostalgia" das línguas latinas, ligada ao retorno - qualquer retorno, não especificamente à terra natal; talvez a "procura de ver" o que é próprio ao coração adoentado, deprimido de que se encontra afastado de seu ambiente, na Sehensucht romântica seja o termo que mais se aproxime de "saudade", palavra de etimologia confusa e incerta de "saudade".

Saudade é a chave do sentimento abordado no poema gonçalvino. A hermenêutica de seus versos se inicia pelo vocábulo do alto latim, solitatem, de solitas, que significa "isolamento, solidão", conforme o apontam Carolina Michaelis ou José Pedro Machado. Mas há quem advogue a precedência do árabe saudah. Fato é que o eu-lírico da "Canção do exílio" sonha com o retorno, com um nóstos que, para ele, estava sendo tão largo e sofrido quanto o foi o do itacense Ulisses. 
A técnica de Gonçalves Dias é diluir a história e oferecer a nossa terra como grande elemento de valorização do nacional, ostentando formularmente uma identidade "minha terra tem palmeiras/onde canta o sabiá", como fazem os aedos, "menestréis divinos" - já que no Brasil o próprio tem sido, desde os tempos oitocentistas, derivado do alheio.

O percurso da ontologia do exílio começa com um expoente do Romantismo brasileiro até chegar aos poetas gregos contemporâneos, percurso que inverte as coordenadas a que a Odisseia homérica se destinou - se esta partir da tradição grega para a posteridade ocidental. Neste capítulo selecionamos um poema do Brasil oitocentista à poesia grega. Em todos os poemas, as vozes poéticas experienciaram de algum modo o afastamento de sua terra e expuseram um aspecto deste sentimento de exílio em seus versos.

Gonçalves Dias - o nostálgico

"Canção do Exílio"

"Minha terra tem palmeiras,

Onde canta o Sabiá;

As aves, que aqui gorjeiam,

Não gorjeiam como lá.

Nosso céu tem mais estrelas,

Nossas várzeas têm mais flores,

Nossos bosques têm mais vida,

Nossa vida mais amores.

Em cismar, sozinho, à noite,

Mais prazer encontro eu lá;

Minha terra tem palmeiras,

Onde canta o Sabiá.

Minha terra tem primores,

Que tais não encontro eu cá;

Em cismar — sozinho, à noite - 
Mais prazer encontro eu lá;

Minha terra tem palmeiras,

Onde canta o Sabiá.

Não permita Deus que eu morra,

Sem que eu volte para lá;

Sem que desfrute os primores

Que não encontro por cá;

Sem qu'inda aviste as palmeiras,

Onde canta o Sabiá."

(In Primeiros Cantos,1846, ed. Laemmert)

Em continuidade a antologia poética e iniciando com os autores gregos que muito se inspiraram em Ulisses como temática de suas obras serão inseridos poemas através de tradução em espanhol do Professor Miguel Castillo Didier e a versão do espanhol para o português é de autoria própria.

Alfred Tennysson - $\mathrm{o}$ antinóstos

Escrito em 1833 e publicado em 1842, este poema é frequentemente citado na literatura mundial para ilustrar o monólogo dramático. Trata-se de um tipo de poema empregado por muitos poetas do período Vitoriano, quando um personagem de ficção ou histórico discursa explicando os seus sentimentos, ações ou motivações. O monólogo é geralmente dirigido a uma plateia silenciosa, com as palavras do orador influenciadas por uma situação crítica. De forma geral, a tradição dramática pode ter influenciado o estilo do monólogo, que tem a pretensão de invocar toda uma história através de representação de uma de suas partes.

Alfred Tennyson, um intelectual formado pelo prestimoso Trinity College, em Cambridge, viveu longos anos com sua esposa na ilha de Wight, por seu amor à vida sossegada do campo. Talvez este minúsculo aspecto biográfico tenha algo a dizer sobre o poema que o fez trazer de volta Ulisses aos versos modernos.

Neste monólogo, Ulisses descreve para uma plateia indeterminada seu descontentamento e sua angústia após o retorno à Ítaca, depois de uma longa peregrinação. Enfrentando a velhice, Ulisses anseia por viajar e explorar o mundo novamente, apesar de seu reencontro com Penélope e seu filho Telêmaco. Alguns 
críticos acham que o Ulisses de Tennyson lembra o de Dante Alighieri, no Inferno (Canto XXVI). Em Dante, Ulisses foi condenado ao inferno juntamente com os falsos conselheiros, tanto pela sua perseguição contínua ao conhecimento além dos limites humanos quanto pelo espírito aventureiro, de alguma forma desrespeitoso em relação à sua família.

Tennyson é o primeiro a dar um tratamento moderno a Ulisses. De volta a Ítaca e confrontado novamente com a vida doméstica, nosso herói exprime um descontentamento que contrasta com a inquietação e o enfado vividos em seu passado heroico. Contempla sua idade avançada e a sua eventual morte - "vida sobre vida" - e anseia por mais experiência e conhecimento. Quer se colocar em marcha novamente.

Telêmaco vai herdar um trono que ele acha tedioso. Como pai, Ulisses acha que seu filho será um rei adequado: "ele trabalha seu trabalho, eu o meu" (v. 43), deixando bastante claro que cada um possui um destino e uma função, pois Telêmaco o deve substituir na condução do governo de Ítaca, e ele, Ulisses, seguir ou retomar seu percurso de busca contínua.

As setenta linhas de versos brancos são apresentadas como um monólogo dramático. Há um forte contraste entre o sentimento das palavras de Ulisses e os sons que os expressam, e se busca exprimir os humores conflitantes do herói assim que ele busca certa continuidade entre o passado de emoções e um futuro que o desgosta, gera inquietação e descontentamento com o retorno.

Este Ulisses mora em Ítaca e, em função das atribulações e responsabilidades que tem de reassumir, sente saudades da vida preguiçosa que ele levava em Ogígia, trancado na pequena ilha e ocupado com poucos negócios.

A lembrança de suas viagens não lhe dá paz. Ele quer viajar de novo, ele quer viajar sempre. Ele se angustia com a ideia de sua carreira heroica ter-se acabado. Diz "Beberei a vida até as borras. Beberei a vida às borras" (v. 7). Ele conta o quanto viu e soube no passado - grupos de homens, costumes, cidades e governos - e se gaba, "fui amado". Mas essa experiência passada lhe abre o apetite, não se apaixona pelas experiências, pelos portos deixados para trás e sim por aqueles que ainda pretende ver e em que gostaria de atracar.

A história de Ulisses se dá através de estágios progressivos autorrevelantes. Não, são estágios que vão sendo revelados aos poucos, em pequenas doses, à medida que ele vai sendo envolvido pela rotina cotidiana, e não irônicos: começa 
por sua rejeição da vida doméstica (que, antes, lhe faltava) e, lembrando-se com saudosismo de seu passado, reconhece a validade do método de governo de Telêmaco. Com esses pensamentos autojustificativos, planeja iniciar uma nova jornada.

O exílio transformou-o e às suas convicções, por fora e até por dentro: prevaleceram nele as memórias recentes.

\section{Alfred Tennysson- "Ulysses"}

(Tradução da autora a partir da tradução em espanhol de Miguel Castillo Didier)

De nada me serviria viver como um rei entre o descanso junto ao caloroso lar, entre cavernas desérticas, unido a uma senil mulher, guia de leis que criei e administro a uma indómita raça que dorme e engorda e procria e não me compreende.

Não posso descansar das viagens. Beberei a vida Até o último suspiro. Sob todos os signos intensamente gozei e ao mesmo tempo sofri, em união com todos aqueles que me amaram, e em minha solidão; no litoral e quando as Híades $^{22}$ chuvosas ofenderam, com marcas inconstantes, o escuro mar. Já me converti em um nome; sempre deambulando com um coração ávido, Eu muito conheci e apressei - cidades de homens, costumes, climas, assembleias, governos e eu, não menos importante, sempre notado por todos e com meus companheiros bebi a bem-aventurança celestial remoto nas planícies que circundam Troia com ventos

Sou uma parte de tudo o que encontrei. Ainda é toda experiência como arco sob o qual resplandece o inundado mundo cujo horizonte a cada momento e continuamente e logo sempre se escapa a minha busca.

Quão insensato seria deter-se, delimitar a fronteira, Enferrujar sem arder e não brilhar na discussão! Como se o respirar fosse a vida! Vida sobre vida foram todas muito pouco e de uma muito pouco me resta;

\footnotetext{
${ }^{22}$ Nome de uma constelação situada muito proximamente às Plêiades. Aparecem na estação das chuvas primaveris, donde a etimologia popular que as aproxima de hýein, 'chover". As Híades eram ninfas, filhas, de Atlas e de uma Oceânida, seres marinhos, portanto. Antes de serem transformadas em constelação, foram amas de Dioniso, elas se teriam suicidado após a morte do irmão, Hias, o que lhes atesta a sororidade e o amor fraterno. Receberam muitos nomes, de acordo com a imaginação dos mitógrafos.
} 
mas cada hora resgatada desse eterno silêncio, mais é portadora de novas criaturas; e por vil que fosse sob três sóis me redimiria e este exaurido espírito ansioso por perseguir conhecimento que, errática estrela, está por sobre o recôndito limite da humana sapiência.

Este é meu filho, meu próprio Telêmaco, tão bem amado, em quem resigno a ilha e o cetro, porque já sabe como cumprir seu trabalho, e com ágil prudência e com manhosa tática subordiná-la ao útil e bom. Todos o acatam, centrado na esfera de tarefas comuns, honesto para sobrelevar missões de ternura, e submissão venerar os deuses íntimos, quando eu tiver partido.

Ele realiza seu trabalho, enquanto eu cumprirei com o meu.

Ali descansa o porto, acelera a embarcação a sua rota E os sombrios mares se dilatam imensos. Meus marinheiros, almas que cortei e esculpi e pensei comigo

- que você acolheu com exultação trovões e sóis, e você se opôs a livres corações e semblantes livres -, já somos velhos; mas a velhice também tem uma honra para seu propósito. A morte fecha tudo; mas para homens aliados/unidos dos deuses há algo adequado antes do término.

As luzes começam a piscar entre as rochas; o longo dia se esvai; a lua sobe lentamente; a profundidade ruge com inúmeras vozes.

Amigos, venham, não é tarde demais para buscar um mundo mais novo. Comecem e, sentem-se em ordem, batam na planície sonora; será meu propósito navegar além do pôr do sol, além de onde as estrelas poentes caem até que eu morra.

Talvez nos submerjam os golfos, talvez atraquemos nas prósperas ilhas e vamos ver Aquiles, o mesmo que uma vez conhecemos valente.

Embora muito tenha sido tirado de nós, muito permanece; e embora não sejamos agora a energia que outrora comoveu céus e terra, nós somos quem somos, uma igual serenidade de corações heroicos, enfraquecidos pelo tempo e pelo destino, mas implacáveis para se esforçar, inquirir, encontrar e nunca desistir.

Miguel Castillo Didier. Un milenio de poesía griega (2004). Santiago: Centro de Estudios Griegos.

Yorgos Sarandis, o desenraizado 
Este autor grego que nasceu em Atenas em 1920 e morreu na mesma cidade em 1978 também trabalho exaustivamente o tema do exílio. Estudou Ciências Políticas na Universidade de Atenas, sem chegar a ingressar nesta carreira. Seus livros de poesia: Impressões dispersas (1939), Sóis ao entardecer (1948), Laurion (1949), Cidade sem nome (1954), os caminhos que temos amado (1958), Poemas seletos I (1963), Poemas seletos II (1972). Como homem progressista descreveu com muita sensibilidade os horrores e penúria dos anos da Guerra Civil (1947-1949).

Tasos Vurnas, na revista Epitheórisi Tejnis, abril de 1958, escreveu sobre Sarandis: "Seus versos têm a calma velocidade de uma pincelada realista sobre um quadro complexo, em cujo fundo vai se encontrar uma aurora instantânea". Traduziu vários poetas europeus, entre outros, Eliot, e o soviético da Geórgia Maiakovsky. Em alguns períodos foi Vice-presidente da sociedade de Escritores Gregos.

Trata o anseio de retorno através de uma perspectiva especial e realista: o retorno à pátria é uma malfadada ilusão, uma enganosa tentação enviada pelos deuses a Ulisses como castigo por suas faltas. Sim, retorna, volta a uma Ítaca devastada, a uma solitária ex-pátria. Pois ali não se acomoda mais, sua alma modificada não se contenta com a vida doméstica e previsível em família. O desterro foi perverso. Perdeu suas raízes, o desenraizamento e a desterritorialização se tornaram permanentes. O poeta descreve o motivo de Ulisses ter sofrido tantas agruras por ter contribuído ativamente na Guerra de Troia e com sua queda. Daí seriam advindas muitas das vinganças e infortúnios do herói.

\section{Yorgos Sarandis - "Odisseo"}

(Tradução da autora a partir da tradução em espanhol de Miguel Castillo Didier)

Já que você foi a causa do desaparecimento de Troia não se surpreenda ao se encontrar sob perseguição divina lutando com deuses invejosos e esperanças grosseiras não se surpreenda você, o mais engenhoso entre os homens.

A primeira emboscada dos deuses é a nostalgia, é o jogo tolo com sua alma a desventurada quimera do retorno.

Mas o que você está esperando para viajar em sua sorte negra?

Mas, o que você espera fugindo entre os anos?

o que você espera quando lhe mata o lamento sombrio de Troia 


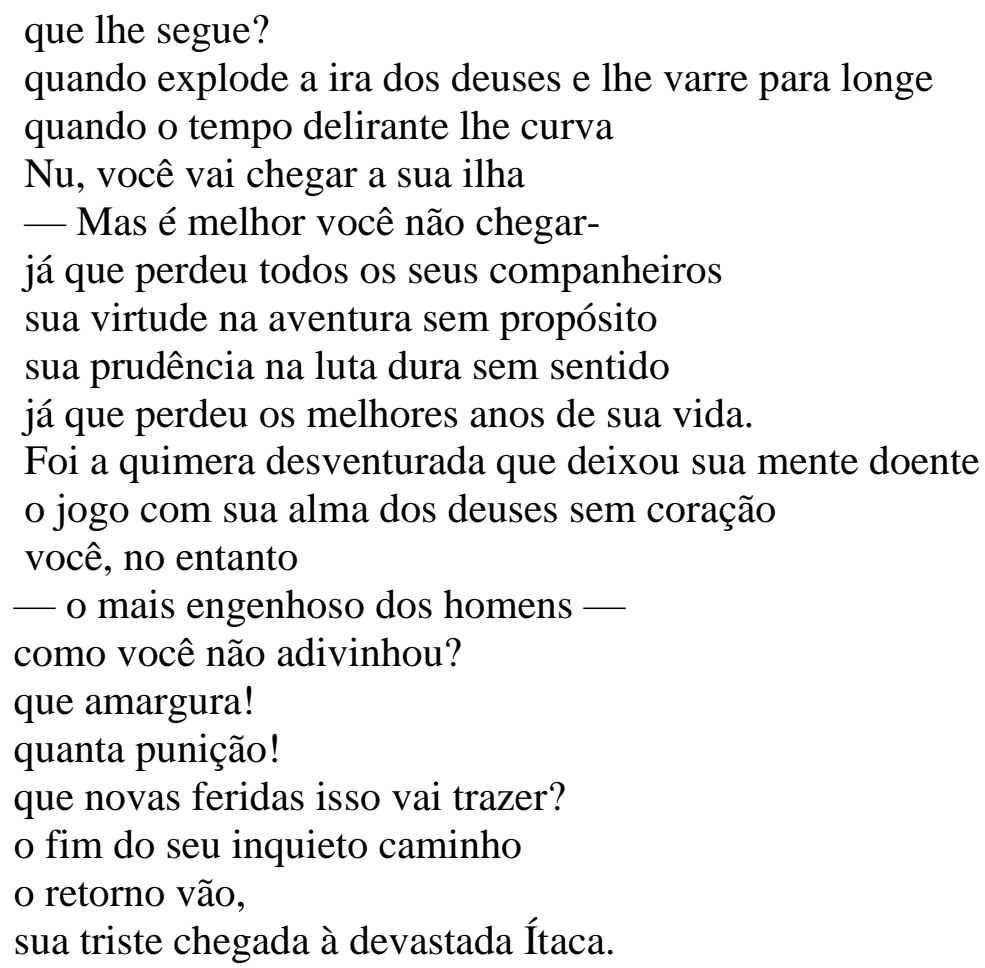

\section{Yorgos Sarandis - "Odisseo"}

Puesto que fuiste el causante de la desaparición de Troya no te extrañes de hallarte bajo persecución divina combatiendo con dioses envidiosos y rudas esperanzas no te extrañes tú el más ingenioso entre los hombres.

La primera emboscada de los dioses es la nostalgia es el juego insensato con tu alma la malhadada quimera del regreso. Pero qué esperas viajando en tu oscura suerte pero qué esperas huyendo entre los años qué esperas cuando te mata el lúgubre lamento de Troya que te sigue cuando estalla la ira de los dioses y te barre cuando te doblega el tiempo delirante Desnudo llegarás a tu isla - pero mejor que no llegarasya que has perdido todos tus compañeros tu virtud en aventura sin objeto tu prudencia en dura lucha sin sentido ya que has perdido los más selectos años de tu vida. Era la malhadada quimera que te enfermó el entendimiento el juego con tu alma de los dioses sin corazón tú sin embargo —el más ingenioso de los hombrescómo no adivinaste qué amargura 
cuánto castigo

qué nuevas heridas traerá

el fin de tu inquieto camino

el vano regreso

tu triste arribar a la Itaca asolada.

Miguel Castillo Didier. Un milenio de poesía griega (2004). Santiago: Centro de Estudios Griegos.

\section{'Segunda Odisseia ${ }^{23 "}$ (1894)}

Constantine P. Cavafy (Kavafis), nasceu em Alexandria em 1863. Ainda que tivesse nascido no Egito Otomano, Kavafis pertencia a numerosa colônia helênica que floresceu nessa cidade mediterrânea. A condição de estrangeiro, na própria terra, pode ser realçada pelo fato de ele conhecer muito pouco o árabe, língua materna da quase totalidade da população egípcia. Mas é sempre importante lembrar que a Alexandria, do período em que viveu Kaváfis, era cercada por um contexto social bem mais cosmopolita do que o que se apresenta em nossos dias, resultado da política de nacionalização empreendida, na década de cinquenta do século XX, pelo, então, presidente egípcio Gamal Abdel Nasser.

O seu pai morreu em 1870, deixando a família em precária situação financeira. A sua mãe e os seus seis irmãos mudaram-se para Inglaterra dois anos depois. Devido à má administração dos bens da família por parte de um dos filhos, a família foi forçada a regressar a Alexandria, na pobreza.

Os sete anos que Kaváfis passou em Inglaterra foram importantes na formação da sua sensibilidade poética. O seu primeiro verso foi escrito em inglês (assinando 'Constantine Cavafy'), e o seu subsequente trabalho poético demonstra uma familiaridade substancial com a tradição poética inglesa, em particular as obras de William Shakespeare e Oscar Wilde.

Os anos que se seguiram, de regresso a Alexandria, representaram tempos de pobreza e desconforto, mas revelaram-se igualmente significativos no desenvolvimento da sensibilidade de Kavafis. Este escreveu os seus primeiros poemas - em inglês, francês e grego - durante este tempo, em que aparentemente também teve as primeiras relações homossexuais.

\footnotetext{
${ }^{23}$ Este poema está arrolado entre os poemas inéditos de Kaváfis, de acordó com Miguel Castillo Didier, organizador de Kavafis íntegro. $2^{\mathrm{a}}$. Ed., Comemorativa dos 70 anos de falecimento do poeta (Santiago de chile: Universidade de Chile/Centro de Estudios Griegos, Bizntinos y Neohelénicos "Fotios Malleros"/ Quid Ediciones, 2003.
} 
Tendo trabalhado durante trinta anos na Bolsa de Valores Egípcia, Kavafis permaneceu em Alexandria até sua morte, que ocorreu em 1933, por motivo de câncer de laringe.

Kaváfis era um cético e questionava a Cristandade, o patriotismo e a heterossexualidade. Publicou 154 poemas e cerca de mais uma dúzia permaneceram incompletos ou no esboço.

Neste poema mostra um Ulisses, já velho, que sai para o mar novamente, curvando-se "em direção à Ibéria". Nesta fuga, ele se sente revivido, e "seu coração aventureiro se regozija friamente", abandonando a terra em função da qual perseverou e sofreu até retornar. Esta Ítaca de agora já não é mais cantada em rapsódias ou por aedos, sem regras métricas.

Todos os sentimentos de Ulisses de quando quis voltar para casa, para sua preciosa Ítaca, para o reencontro com sua fiel Penélope, com seu amado filho Telêmaco, com seus bens e haveres... se dissiparam. Este foi o motivo da odisseia de vida. Quando o alcança, a vida acaba, perde sentido. O sofrimento estava lá, tornava-o grande, mas agora seu coração clama por uma nova jornada. $\mathrm{O}$ vazio o impele a uma nova viagem, a aventura é seu verdadeiro amor.

Este poema não constitui nem uma primeira versão do poema canônico "Ítaca”, nem uma reelaboração, já que este foi escrito entre 1910-1911, dezessete anos antes do intitulado "Segunda Odisseia". Deste, Kaváfis aproveitará apenas o motivo da entrada em portos nunca vistos (v. 20-22), no poema escrito posteriormente, uma composição distinta, com características próprias e autonomia poética.

O poema e o ensaio filológico ${ }^{24}$ "O fim de Odisseu", ambos escritos em 1894, compaginados, fornecem elementos que ultrapassam o eixo temático de ambos, a morte do herói. Kaváfis não nega, ao contrário, demonstra a presença de Homero, Dante e Tennyson (que ele traduz e estuda no artigo), em sua obra.

\section{Dante: "Inferno. Canto XXVI"}

\footnotetext{
${ }^{24}$ O artigo foi publicado na revista Dokimasía, Ioanina, II. 5, jan.-fev. 1974. Não chegamos a consultá-lo pela dificuldade de acesso. Consultamos, entretanto, o artigo de ORTIZ, Alicia Morales. "Más allá de Ítaca: La Segunda Odisea de Cavafis", Estudios Románicos, Vol. 16-17, 2007-2008, pp. 747-763.

https://www.academia.edu/3999697/M\%C3\%A1s_all\%C3\%A1_de_Itaca_La_Segunda_Odisea_d e_Cavafis. Acesso em 19/10/2020.
} 


\section{Tennyson: "Ulysses"}

(Tradução da autora a partir da tradução em espanhol de Miguel Castillo Didier)

Segunda e grande odisseia, talvez maior que a primeira. Mas ai! sem Homero, sem hexâmetros.

A casa de seu pai era pequena, a cidade de seu pai era pequena, e toda a sua Ítaca era pequena.

A ternura de Telêmaco, a fé de Penélope, a longevidade do pai, seus velhos amigos, o amor das pessoas altruístas, o doce repouso do lar, penetraram como raios de alegria no coração do navegante.

E quais raios se apagaram, A sede do mar acordou dentro dele. Ele odiava o ar do continente. Seus sonhos perturbados à noite os fantasmas de Hespéria ${ }^{25}$. Venceu-lhe a saudade das viagens e das chegadas matinais nos portos onde, com que alegria você entra pela primeira vez?

A ternura de Telêmaco, a fé de Penélope, a longevidade do pai, seus velhos amigos, o amor das pessoas altruístas, paz e descanso. da casa o entediava. E foi embora. Quando as costas de Ítaca foram desaparecendo aos poucos na frente dele e navegava para o oeste a toda vela, em direção à Ibéria, às colunas de Hércules ${ }^{26}$.-

25 "Terra ccidental", nome poético que designava Itália ou Espanha (HARVEY, D. Dicionário Oxford de Literatura Clássica. Trad. Mário da Gama Kury. Rio de Janeiro: Jorge Zahar, 1987. P. 271). Etimologica-mente, local da Terra onde cai o sol, é belo e quente o entardecer (hespéra, "tarde"). As Hespérides (filhas da Tarde) viviam aí, local distante, na direação do oeste, perto das montanhas Atlas, guarndando a árvore que dava pomos de ouro, guardada por um animal mitológico. Foi um dos trabalhos de Héracles resgatar os ambicionados pomos. O "Jardim das Hespérides" era um lugar utópico, de prazer incesante.

${ }^{26}$ Ou Colunas de Atlas, Estreito de Gibraltar. 
longe de todo o mar Aqueu ${ }^{27}$-, sentiu que ele reviveu, que

jogou fora as amarras pesadas

de coisas familiares e íntimas.

E seu coração aventureiro

regozijava friamente, vazio de amor.

\title{
Constantino Kavafis - Segunda Odisea (Janeiro/1894)
}

\author{
Dante: "Infierno. Canto XXVI" \\ Tennyson: "Ulysses"
}

Odisea segunda y grande, mayor quizás que la primera. Pero ay

sin Homero, sin hexámetros.

Era pequeña su casa paterna, era pequeña su ciudad paterna, y toda su Itaca era pequeña.

La ternura de Telémaco, la fe de Penélope, la ancianidad del padre, sus antiguos amigos, el amor del abnegado pueblo, el dulce reposo del hogar, penetraron cual rayos de alegría en el corazón del navegante.

Y cual rayos se apagaron, La sed del mar se despertó dentro de él. Odiaba el aire de la tierra firme. Sus sueños turbaban por la noche los fantasmas de Hesperia. Lo venció la nostalgia de los viajes, y de las llegadas matinales a los puertos donde, con qué alegría, entras por primera vez.

La ternura de Telémaco, le fe de Penélope, la ancianidad del padre, sus antiguos amigos, el amor del abnegado pueblo,

\footnotetext{
${ }^{27} \mathrm{O}$ mar dos gregos é o Egeu. Kaváfis, para poeticamente fazer justiça aos verdadeiros dominadores do mar grego, rebatiza-o, no poema. "Aqueus" foram os antepassados mais remotos dos povos da Grécia clásica e da Ásia Menor, que, no séc. XV a.C., chegam da Europa central, falando língua indo-europeia. Tornaram-se navegadores. Desembarcaram em Creta e a venceram. Como de costume, os vencidos mais cultos conquistaram os vencedores. Da aculturação aqueu-cretense nasceu a civilização MICÊNICA (1.600-1.100 a.C.), que tinha como centro a poderosa cidadela de Micenas, no Peloponeso. É a este período que se remetem os eventos históricos, navegações e mitos narrados por Homero.
} 
la paz y el reposo

de la casa lo aburrieron.

Y se marchó.

Cuando las costas de Itaca

se desvanecían poco a poco frente a él

y navegaba hacia occidente a toda vela,

hacia Iberia, hacia las columnas de Hércules.-

lejos de todo mar aqueo -,

sintió que revivió, que

arrojó las pesadas ataduras

de cosas conocidas y domésticas.

Y su corazón aventurero

se regocijaba fríamente, vacío de amor.

Miguel Castillo Didier. Un milenio de poesía griega (2004).

Santiago: Centro de Estudios Griegos.

\section{Yorgos Seferis (1900-1971) -}

Traz, desde o início de sua produção, um velho personagem que fala a mesma língua que ele - como falaram três mil anos antes - e o resgata como um maestro que pode ainda hoje nos dar ensinamentos. Em contraste com os versos atormentados de Sarandis, os de Seferis respiram serenidade, não sem tristeza.

Nascido em Esmirna em 1900, Seferis foi para o exílio aos 14 anos, a distância de sua terra natal se tornou perpétua em 1922, quando a grande Catástrofe de Esmirna levou à morte dezenas e dezenas de milhares de gregos e ao desterro sem volta mais de um milhão e meio de pessoas que habitavam a costa do Mar Negro, a Capadócia e a Asia Menor. Não é estranho que o poeta da Jonia grega se "sinta cercado pelo desterro" e evoque Ulisse e sua viagem nostálgica para a pátria e o lar e o navegante que sabia da difícil dor de sentir as velas do barco preenchidas por uma lembrança. O poeta reflete "feliz aquele que fez a viagem de Ulisses, feliz se partiu com a armadura do amor, com a qual poderá vencer as dificuldades!"

No poema abaixo o autor ressalta a angústia de Ulisses durante o tempo em que é feito prisioneiro por Calipso, onde a dor da distância é sentida diariamente e o herói se vê contínua e reiteradamente preso a costa da ilha de sua carcereira, quando pulsa o seu desenraizamento. Manifesta seu sofrimento e o desejo de partir em busca de seu território, não se deixa seduzir pela imortalidade proposta por ela e almeja retomar seu caminho de volta ao lar. Almeja se libertar de seu confinamento, do afastamento de seu território. Se tornou um apátrida, não se identifica com o lugar onde está e não consegue voltar a seu local de origem: sua tão sonhada Ítaca! 


\section{"Odisseu a Calipso"}

(Tradução da autora a partir da tradução em espanhol de Miguel Castillo Didier)

Seu corpo resplandece como um templo na rocha, ereto e branco como a neve. E seus peplos ${ }^{28}$ apenas com o passar do tempo os movem, como as brisas os mares.

Mas dentro do meu sangue mortal corre, que queimam paixão antiga, ódio e dor; e congela a imortalidade que impõe e continuo agarrado a sua pedregosa costa.

Quero partir. Da morte o destino Está profundamente enraizado em meus ossos. Me puxa da porta do Olimpo

a vida humana mil vezes mais amarga. Liberte-me agora de sua rede enganosa, para viver, para lutar, para morrer.

\section{Yorgos Seferis -"Odiseo a Calipso"}

Tu cuerpo resplandece como un templo en la roca enhiesto y blanco cual la nieve. Y tus peplos sólo al pasar los tiempos los mueven, como las brisas a los mares.

Mas dentro de mí sangre mortal corre, que queman pasión antigua, odio y dolores; y la hiela la inmortalidad que impones y quedo aferrado a tu pétreo costado.

Quiero partir. De la muerte el destino está en mis huesos muy enraizada.

Me hala desde la puerta del Olimpo

la vida del humano la mil-veces-amarga. Líbrame ya de tu engañosa red, para vivir, para luchar, para morir.

\footnotetext{
${ }^{28}$ Veste tanto feminina quanto masculina que se sobrepõe ao vestido interno, preso por um broche,
} na altura de um dos ombros. 
Miguel Castillo Didier. Un milenio de poesía griega (2004). Santiago: Centro de Estudios Griegos.

\section{Constantino Kaváfis (1869-1933)}

O poema "Ítaca" (1911) de Kaváfis é uma experiência de viajar até Ítaca (que pode ser qualquer lugar para qualquer pessoa), é para onde se acalenta o desejo de voltar ao solo pátrio.

É a suposição de um início de jornada ou percurso, “quando saíres em viagem para Ítaca", tome fôlego, equipe-se e vá firme, determinado em seu propósito, com a vista sempre focada na chegada. "Pede que o caminho seja longo", há uma ponte para que o caminho seja prazeroso, e a jornada possa ser valorizada. Mais até do que a chegada.

Todo o roteiro da Odisseia homérica serve de base para as imagens e conjecturas hipotéticas do poema. Parece mesmo que o eu-lírico se inebria (vv. 1826) com a perspectiva do retorno. Até fugindo ao estilo kafkiano - contido, pouco dado a arroubos ${ }^{29}$ - manifesta-se uma incomum ênfase, no poema, a perfumes, que simbolizam o gozo hedonístico. Claro que não se trata de um deslize do poeta, mas sim do arrebatamento lírico que prevalece.

De fato, Kavafis, como é comum à poesia, apresenta a sua interpretação da Odisseia milenar de Homero.

Posteriormente, Kavafis interpretou o motivo do retorno de Ulisses à ilha natal como um símbolo de plenitude vital. Seja Ítaca o "meta-pretexto", ou a "metacausa" de uma longa caminhada, cheia de novas experiências, novos conhecimentos e novos prazeres; a viagem que por si só tem seu significado.

Mantendo o recorte justificado anteriormente, optei por utilizar a tradução para o espanhol do Professor Miguel Castillo, ainda que sabedora de existirem quatro autores brasileiros que traduziram este icônico poema, a saber José Paulo Paes, Haroldo de Campos, Isis Borges da Fonseca e Ivo Storniolo. Há também uma tradução do autor português Jorge de Sena, que viveu exilado no Brasil que consta no livro "90 e mais quatro poemas" de Constantino Kaváfis.

\section{Constantino Kaváfis - "Ítaca" -}

\footnotetext{
${ }^{29}$ Esta observação se coaduna com o materialismo filosófico que Kavafis defendeu.
} 
(Tradução da autora a partir da tradução em espanhol de Miguel Castillo Didier)

Quando saíres de viagem para Ítaca, deseje que o caminho seja longo, cheio de aventura, cheio de conhecimento.

Aos Lestrigões e aos Ciclopes ${ }^{30}$, Ao irritado Poseidon ${ }^{31}$, não temas.

Coisas assim em tua rota, nunca encontrarás

Se elevado se mantiver teu pensamento, se uma seleta emoção teu espírito e teu corpo embarga.

Aos Lestrigões e aos Ciclopes, ao feroz Poseidon não encontrarás, se dentro de sua alma não os levas, se tua alma não os ergues diante de ti.

Deseja que o caminho seja longo. Que haja muitas manhãs de verão em que com que felicidade, com que alegria entres em portos nunca vistos; detenta-te em mercados fenícios, e compra as belas mercadorias, âmbares e ébanos, marfins e corais, e perfumes voluptuosos de todos os tipos quanto mais abundantes possas perfumes voluptuosos; vai a muitas cidades egípcias, para aprender e aprender com os sábios.

Sempre em teu pensamento mantém à Itaca.

Chegar lá é o teu destino.

Mas não apresse tua viagem em absoluto.

Melhor que muitos anos dure:

e já velho ancores na ilha, rico pelo que ganhaste no caminho, sem esperar que riquezas te dê Ítaca.

Ítaca lhe deu a bela viagem.

Sem ela, não terias saído a caminho.

Outras coisas já não tem para te dar.

E se pobre a encontras, Ítaca não te há enganado.

Sábio assim como chegaste a ser, com experiência tanta, Já terás compreendido as Ítacas, o que é que elas significam.

\footnotetext{
${ }^{30}$ Lestrigões e Ciclopes gigantes antropófagos que Ulisses poderia vir a enfrentar, no tempo futuro hipotético do poema.

${ }^{31}$ Realisticamente, o enfrentamento de um longo mar, cheio de inimigos, físicos e oníricos, reais e imaginários, falantes de língua cognoscível ou estranhos/estrangeiros, o mar de Poseidon é o território de perigos, mesmo sem Ciclopes.
} 


\section{Constantino Kaváfis - "Ítaca" -}

Cuando hacia Itaca salgas en el viaje, desea que el camino sea largo, pleno de aventuras, pleno de conocimientos.

A los Lestrigones y a los Cíclopes, al irritado Poseidón no temas.

Tales cosas en tu ruta nunca hallarás si elevado se mantiene tu pensamiento, si una selecta emoción tu espíritu y tu cuerpo embarga.

A los Lestrigones y a los Cíclopes, al feroz Poseidón no encontrarás, si dentro de tu alma no los llevas, si tu alma no los yergue delante de ti.

Desea que el camino sea largo.

Que sean muchas las mañanas estivales en que con cuánta dicha, con cuánta alegría entres a puertos nunca vistos; detente en mercados fenicios, y adquiere las bellas mercancías, ámbares y ébanos, marfiles y corales, y perfumes voluptuosos de toda clase cuantos más abundantes puedas perfumes voluptuosos; anda a muchas ciudades egipcias, a aprender y aprender de los sabios.

Siempre en tu pensamiento ten a Itaca. Llegar hasta allí es tu meta.

Pero no abrevies el viaje en absoluto. Mejor que muchos años dure: $\mathrm{y}$, viejo ya, ancles en la isla, rico por cuanto ganaste en el camino, sin esperar que riquezas te dé Itaca.

Itaca te dio el bello viaje.

Sin ella no habrías salido a la ruta.

Nada más tiene que darte.

Y si pobre la encuentras, Itaca no te ha engañado.

Sabio así como llegaste a ser, con experiencia tanta, habrás ya comprendido las Itacas, qué es lo que significan.

Miguel Castillo Didier. Un milenio de poesía griega (2004). Santiago: Centro de Estudios Griegos.

Desta forma apresentamos esta antologia de autores gregos que tematizaram o exílio e de forma contundente o exílio de Ulisses. São pungentes nos poemas as palavras da ontologia do exílio que permeiam os versos. Ao ler cada um deles podemos nos aperceber da dor antinatural da condição do exilado que tem sua noção 
de pertencimento abalada, fica despido da sensação de origem, não pode caminhar pelos lugares que nos evocam ao nosso lugar de origem, pois se encontram em terras ou lugares alheios. O desenraizamento que esta circunstância de afastamento causa naquele que está desterrado pode ser percebido nas palavras que os autores se utilizam para traduzirem as angústias e ausências, faltas que Ulisses sofre ao estar de volta a sua terra natal, Ítaca. Tais lacunas ao serem transformadas em escritos geram uma genealogia literária da questão do exílio que produz uma rentabilidade vocabular característica e peculiar do tema, que retratam a enormidade da viagem do abandono da terra natal, dos cheiros, das memórias. Há muitos aspectos da pulsação da língua poética que são transformados em ecos, continuam em aberto acalentando o momento da volta, do retorno ao lar. Estes poemas não estão aqui apenas para ilustrar a sobrevivência do personagem, a busca pelo direito a ter raízes, dar continuidade à vida em um lugar que é seu. A manutenção da temática do exílio e do sentimento exílico permance pela extirpação do lugar de origem, pela expulsão de um território que confere a existencialidade, por não falar a língua materna, pela ausência dos cheiros da origem e pela falta das referências geográficas. Ulisses vai para o Norte, um homem do mar que se dirige para o gelo não quer mais sentir a terra sob seus pés. 


\section{5 \\ Nota final}

A maneira de contar as histórias baseadas nas obras clássicas usam a capacidade de narrar com o recurso de padrões, fórmulas...

A palavra-chave é INDEBTEDNESS, ou seja, “dívida”. A bem da verdade, não há empréstimo, nem influência de Homero, na concepção e concretização da Odisseia de Kazantzákis. Há dívida, porque, não existisse a Odisseia oral, primeira, fundacional, não existiria a Odisseia moderna, disruptiva, desconstrutora, oposta ao modelo homérico.

Dívida de "ingratidão", pode-se pensar, porque destrói o "pai", o texto fundador, como o profetizou Platão, no Fedro, como o mito de Thot. Mas sempre dívida.

A importância dos paralelismos e das "desparalelizações" enfatizam a originalidade nas inovações estilística e imagística do poema moderno, mas frisando, com Shaw, que "The innovation which does not move aesthetically is of interest only to the formalista" (p. 86). Kazantzákis é genial, porque ousado, dessacralizador, coerente com suas convicções de materialista agnóstico.

A odisseia de Kazantzákis se inicia com grande detalhismo geográfico apoiado na decritividade homérica - e, à medida que o protagonista vai se embrenhando em território africano, vai penetrando no Coração da terra - a raiz mesma da vida humana, Segundo a arqueologia e as pesquisas sobre os primeiroa hominídeos na Terra - as referências topográficas vão desaparecendo, até ficar apenas o registro dos icebergs perdidos no oceano gelado da Antártida. Até o momento que Ulisses entra na África há muitas referências geográficas. Mas as marcas topográficas e humanas vão-se esgarçando ao longo da travessia do herói. O deserto, as montanhas, planícies, savannas e florestas levam ao mar. À imensidão, à solidão. Isto é preciso de se dizer.

Perdem-se os nomes, mas afloram as paisagens, até que resta só a temperature gélida, onde a vida se conservará para a eternidade. 
6

\section{Referências bibliográficas}

ADRADOS, F. R. Introducción a Homero. Barcelona: Labor, 1984.

AGAMBEN. Política del exilio. Archipiélago. Cuadernos de crítica de la cultura. Barcelona. № 26-27. 1996.

ALIGHIERI, Dante. A Divina Comédia. Trad. José Pedro Xavier Pinheiro. São Paulo: Gráfica e Editora Edigraf Limitada, 1958.

AUBRETON, Robert. Introdução a Homero. São Paulo: Difusão Europeia do Libro/EDUSP, 1968.

AUERBACH, Erich. Figura. São Paulo: Ática, 1997.

A cicatriz de Ulisses. In: Mímesis. São Paulo: Perspectiva, 1998.

BAUDIER, M.L. Nikos Kazantzákis. Cómo El hombre se hace inmortal.

Buenos Aires: Ediciones Carlos Lohlé, 1987.

BEYE, C. R. Odisseu: uma vida. São Paulo: Odysseus, 2006.

BERNARDES, Carolina Dônega. A Odisseia de Nikos Kazantzákis: Epopéia

Moderna do Heroísmo Trágico. Rio de Janeiro: Cassará Editora, 2012.

BOITANI, Piero. A Sombra de Ulisses. Trad. Sara Margelli. São Paulo:

Perspectiva, 2005.

BORGES. Jorge Luis. As versões homéricas. In: Obras Completas. Trad. Josely Vianna Baptista. São Paulo: Globo, 1998. V.1.

BOWRA, C.M. Heroic Poetry. 5th. edition. London. The Macmillan Press Ltd., 1978.

BRUNEL, Pierre. Dicionário de Mitos Literários. Trad.Carlos Sussekind... [ET al.]. Rio de Janeiro: José Olympio, 1997.

BULFINCH, Thomas. O Livro de Ouro da Mitologia. A Idade da Fábula. Histórias de Deuses e Heróis. Trad. David Jardim Júnior. Rio de Janeiro: Ediouro, 1965.

BURELLO, Marcelo G.; ROMANDINI, Fabián Ludueña; TAUB, Emmanuel (Eds.). Políticas Del exílio. Origenes y vigência de um concepto. Buenos Aires: Editorial de La Universidad Nacional de Tres de Febrero, 2011.

CALVINO, I. As odisseias na Odisseia. In: Por que ler os clássicos. São Paulo: Companhia das Letras, 2000.

CAMPBELL, J. O herói de mil faces. São Paulo: Cultrix/Pensamento, 2007. 
CASTILLO DIDIER, M. Algunas notas sobre la Odisea de Nikos Kazantzakis. Revista de la Universidad Técnica del Estado, $\mathrm{N}^{\circ}$ 5, 1971.

CASTILLO DIDIER, M. Introducción a la versión castellana de la Odisea, Obras Selectas vol. IV, Planeta, Barcelona, 1975.

CASTILLO DIDIER, M. La Odisea en la Odisea Estudios y ensayos sobre la Odisea de Kazantzakis. Centro de Estudios Griegos, Santiago 2006-2007.

CASTILLO DIDIER, M. Dos Odiseas. Introducción de la Odisea. Tajamar Editores, Santiago 2013.

CASTILLO DIDIER, M. El tiempo, la muerte y la palabra en la Odisea de Kazantzakis. Centro de Estudios Griegos, Santiago 2018.

CITATI, P. Ulisses e a Odisseia. Lisboa, Edições Cotovia, 2005.

DERRIDA, Jacques. Da hospitalidade. Trad. Antônio Romane. São Paulo: Escuta, 2003.

DIDIER, Miguel Castillo. Odisea de Kazantzakis. Traduccin, estudio, notas, síntesis en prosa y bibliografía. Tajamar Ediciones, Santiago 2013.

DIDIER, Miguel Castillo. Odisea por Plantea, Barcelona, 1975, en el IV tomo de Obras Selectas de Kazantzakis.

FOUCAULT, Michel. Ditos e escritos. Conferência no Círculo de Estudos Arquitetônicos, Outros Espaços. Tunísia.1967/Architeture, mouvemente, continuité, $\mathrm{n}^{\circ} 5$, outubro de 1984.

FRIAR, Kimon. The Odyssey: A Modern Sequel by N. K. Translation into English Verse Introduction, Synopsis and Notes, Simon and Schuster, Nueva York, 1958.

FRIAR, Kimon. La ascesis espiritual de N. Kazantzakis, Nea Hestía, Navidad 1959, pág. 58 y sig.

FOUCALT, Michel. «Outros espaços » (conferência no Círculo de Estudos arquitetõnicos. 14 de março de 1967), Architecture, mouuement. contlnuité. n2 5. outubro de. 1984. ps.46-49.

Constantino Cavafy: 90 e mais quatro poemas. [tradução, prefácio, comentários e notas do poeta Jorge de Sena]. Porto: Editorial Inova, 1969.

Poemas. Konstantinos Kaváfis. [tradução e seleção José Paulo Paes]. Edição bilíngue. Rio de Janeiro: Nova Fronteira, 1982. 
Poemas. Konstantinos Kaváfis. [seleção, estudo crítico, notas e tradução José Paulo Paes]. Coleção Sabor Literário. Rio de Janeiro: José Olympio, 2006.

Poemas de K. Kaváfis. [tradução Isis Borges Borges da Fonseca]. edição bilíngue. São Paulo: São Paulo: Odysseus Editora, 2006; reed. 2015.

Konstantinos Kaváfis: 60 Poemas. [seleção e tradução Trajano Vieira]. edição bilíngue. $1^{a}$ ed., São Paulo: Ateliê Editorial, 2007.

Konstantinos Kaváfis: poemas. [organização Trajano Vieira; tradução Haroldo de Campos]. 1 ${ }^{\text {a }}$ ed., São Paulo: Editora Cosac Naify, 2012.

GAGNEBIN, Jeanne Marie. Lembrar, Escrever, Esquecer. São Paulo: Editora 34, $2^{\text {a }}$ Ed. 2009.

HALL, Edith. The Return of Ulisses A Cultural History of Homer's Odyssey. Baltimore: Johns Hopkins, 2008.

HAVELOCK, Eric. Prefácio a Platão. tradução de Enid Abreu Dobránsky. SP. Papirus, 1996.

SP. Editora Unesp, 1996.

HOMERO. Odisseia; trad. Carlos Alberto Nunes. São Paulo: Melhoramentos, 1962.

HOMERO. Odisseia; tradução e prefácio Carlos Alberto Nunes. - [25. ed.] - Rio de Janeiro: Nova Fronteira, 2015.

HUTGHEON, Linda. A theory of adaptation. New York/London: Routledge, 2006.

KAZANTZÁKIS, Nikos. Odisseia. Trad. Miguel Castillo Didier.XXXX ano

KAZANTZÁKIS, Nikos. Relatório ao Greco. $1^{\text {a }}$ Ed. Trad. Do grego de Lucilia Soares Brandão. Rio de Janeiro: Cassará, 2014.

KAZANTZAKIS, Nikos. Ascese. Os Salvadores de Deus. São Paulo: Ática, 1997.

LONGXI, Zhangi.

MORA, Octavio. Ausência Viva. 41 Poetas do Rio. Org. Moacyr Félix. Rio de Janeiro: FUNARTE, 1998.

NUÑEZ, Carlinda F. Pate. "Uma odisseia no espaço: A geografia na literatura". In: ROSENDAHL, Zeny e CORREAA, Roberto Lobato (orgs.). Temas e caminhos da geografia cultural. Rio de Janeiro: EdUERJ, 2010. Pp. 73-114.

QUEIROZ, Maria José de. Os Males da ausência ou A Literatura de exílio. Rio de Janeiro: Topbooks, 1998. 
RAMOS, Oscar Gerardo. La Odisea Um Itinerário Humano. Bogotá:

Publicaciones Del Instituto Caro y Cuervo Series Minor XI, 1970.

SHAW, J.T. Literary Indebtedness and Comparative Literary Stuydies. In: STALLKNECHT, Newton P. and FRENZ, Horst (Eds.). Comparative Literature: Method and Perspective. London \& Amsterdam: Southern Illinois University Press, 1973.

STAIGER, Emil. Conceitos fundamentais da poética. Rio de Janeiro. Tempo Brasileiro, 1972.

STANFORD, W. B. The Ulysses Theme. A Study in the Adaptability of a Traditional Hero: Basil Blackwell Oxford, 1954.

VERNANT, Jean Pierre. Mito e tragédia na Grécia Antiga [por] Jean-Pierre Vernant e Pierre Vidal-Naquet [tradução de Anna Lia A. de Almeida Prado, Maria da Conceição M. Cavalcante e Filomena Yoshie Hirata Garcia]. São Paulo, Duas Cidades, 1977.

VIDAL-NAQUET, Pierre. O Mundo de Homero. Trad. Jônatas Batista Neto. São Paulo: Companhia das Letras, 2002. 


\section{7 \\ Anexos}

\section{Anexo 1}

\section{ÍTACA}

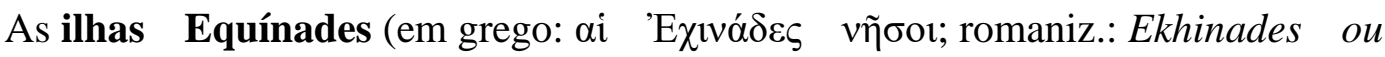

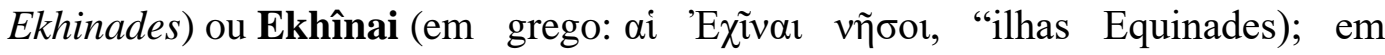
italiano: Curtzolari), também chamadas informalmente Oxeiae ${ }^{32}$ (significando itacenses) são um grupo de 21 ilhas do mar Jónico, ao largo da costa da Grécia, na entrada do golfo de Corinto, 17 das quais nomeadas; 4 são apenas cascalhos flutuantes. O arquipélago se divide em três grupos: as Drakoneres ao norte, as Modia no centro e as Ouniadas ao sul. Administrativamente fazem parte de duas unidades regionais: Ítaca e Cefalônia, ambas parte da antiga prefeitura de Cefalônia. Muitas das ilhas são privadas.

Além de famoso por ser a terra natal de Odisseu, ao largo do arquipélago foram travadas duas importantes batalhas históricas: a batalha das Equínades em 1427, e a batalha de Lepanto, em 1571.

Homero descreve as Equinadas como sendo habitadas (Od. XV, 299), mas não retira da voz do narrador o comentário a respeito da impressão desfavorável que Ítaca oferece ao visitante: o litoral penhascoso, as poucas árvores, a aridez decorrente dos ventos e a desolação da paisagem, tudo muito diferente da paisagem atraente, arborizada e frutífera de Ogígia, a doce e bela ilha de Calipso. No Canto XIII, quando a embarcação providenciada por Alcínoo se aproxima da ilha, Odisseu desperta e mira "um porto dito de Fócis, o velho do mar". A descrição fala por si:

"nele, dois promontórios se projetam em saliências rochosas,

Íngremes do lado do mar, mas inclinados para o porto,

Impedindo as ondas levantadas pelos ventos terríveis

De fora; lá dentro, sem amarras, estão fundeadas as naus bem construídas

(...)

No cabeço deste porto há uma oliveira de esguias folhas,

e perto dela há uma gruta aprazível e sombria"

(Od., XIII, 97-101. Trad. Frederico Lourenço. São Paulo:

Penguin/Companhia das Letras, 2011. p. 337)

"Aprazível" e "sombria" não constituiriam um oximoro? A voz do narrador expressa como Odisseu, com a memória filtrada pelo sono e pela saudade, enxergaria sua terra natal - feia, inóspita, porém sua. A partir daí a descrição contrapõe ao aspecto negativo da paisagem as obras dos homens e dos deuses que a domesticaram. No mesmo canto, Atená desperta o divino viajante:

"que dormia na sua terra pátria, embora a não reconhecesse, pois estava fora há tanto tempo e à sua volta a deusa

Palas Atena, filha de Zeus, derramara uma neblina

Para torná-lo irreconhecível e para lhe explicar tudo primeiro"

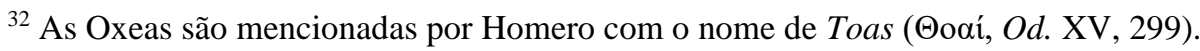


(Od., XIII, 188-191. Idem, p. 340)

O herói poderia tornar-se irreconhecível, mas não a paisagem natal! Soam enganosos os versos com que o aedo enuncia os desfavores da natureza a Ítaca, que Odisseu contempla com olhos talvez realistas, justamente por conta do afastamento que o torna provisoriamente estrangeiro naquele lugar amado:

"Por isto todas as coisas pareciam estranhas ao soberano:

Os caminhos contínuos; os portos, ancoradouros de todos;

Os rochedos escarpados e as árvores frondosas.

Levantou-se e olhou, de pé, para a aterra pátria.

Em seguida gemeu e, batendo com as mãos nas coxas, lamentou-se e proferiu as seguintes palavras:

'Ai de mim, a que terra de homens mortais chego de novo?

Serão eles homens violentos, selvagens e injustos? "

(Od., XIII, 194-201. Idem, p. 190)

As Ilhas Equínades tiveram a sua entrée na poesia através da Ilíada (II, 625). Homero as homenageou, entretanto, à farta, na Odisseia (I, 245; IX, 24; XIV, 335 e 397; XVI, 123, 247 e 396; XIX, 292) e não deixou de mencioná-las no Hino a Apolo (v. 429).

Eurípides, no párodo de Ifigênia en Áulis (v. 322), o Coro identifica as Equínades com as ilhas de Tafos ou Táfias (Taphiae Insulae), de gente valorosa, provavelmente homenageando suspicazmente a Ulisses, nativo da região insular que apoiará o filicídio imposto por Ártemis a Agamemnon.

Ovídio, nas Metamorfoses (VIII, 573b-610), narra a transformação das Náiades em ilhas, justamente o arquipélago das Equínades (literalmente mencionadas no texto latino, v. 589).

“... Teseu, olhando

A vasta extensão das águas, apontou numa direção e perguntou.

'Que lugar é aquele? Qual o nome

Daquela ilha li?' Aqueloo

Respondeu: 'O que você vê não é uma ilha, apenas.

São cinco, mas a esta distância

Parecem uma só. Gostaria de ouvir a história delas?

Diana, a deusa de cabeça dourada não é a única

A ficar terrível quando desrespeitada. Estas eram náiades (naides),

Que certa vez mataram dez novilhos (...)

(OVÍDIO. Met., VIII, vv.575-583. Trad. Vera Lucia Leitão Magyar.

São Paulo: Madras, 2003. Pp. 171-172)

O anfitrião, Aqueloo, narrou a Teseu que se enfurecera com as Náiades, por terem preparado um banquete com os tais novilhos, mas não o convidaram. Enfurecido, ele causou uma inundação tremenda, unindo-se ao mar (Jônio), bem como a outros cursos d'água, e ainda as transformou em ilhas. Logo adiante, no verso 589 (in totidem, mediis quot cernis Echinadas undis ${ }^{33}$ ), as Equínades são citadas: "no

\footnotetext{
${ }^{33}$ P. Ovidius Naso, Metamorphoses. Brookes More, Ed. Perseus Digital Library 4.0.. Tufty University.

http://www.perseus.tufts.edu/hopper/text?doc=Perseus\%3Atext\%3A1999.02.0028\%3Abook\%3D8 \%3Acard\%3D547 Acesso em 25/11/2020.
} 
meio das ondas [pode-se ver] o conjunto das Equínades" (que seriam, miticamente, cinco). A referência foi omitida, entretanto, na tradução em português.

Tucídides (História da Guerra do Peloponeso, II, 102) confirma a esterilidade das Ilhas Equínades.

Estrabão (Geografia, X,2,19) ressalta a aridez e o relevo escarpado das ilhas. Justiça seja feita, este dado da geografia física da região insular - ventosa e escarpada não foi apagado, apesar dos esforços homéricos.

Plinio, o Velho (História Natural IV, 12. s. 19) nomeia a nove delas: Egialia, Cotônide, Tiatira, Geoaris, Dionísia, Cirno, Cálcide, Pinara e Nistro. Outra das Equínadas era Artemita ('A $\rho \varepsilon \varepsilon \mu i ́ \tau \alpha)$, que acabou unida ao continente (Estrabão I, 3, 18; Plinio IV, 1-2). 


\section{Anexo 2}

Na sequência apresento a trancrição do resumo em inglês que foi elaborado pelo próprio Nikos Kazantákis e publicado no livro The Odyssey: A modern sequel de Kimon Friar. O mesmo se encontra nos anexos da obra e foi indexado ao trabalho aqui apresentado com o objetivo de possibilitar a leitura e contato com a sinopse da obra para os membros da banca, devido a esta ainda não ser muito conhecida. Com esta inclusão também é esperado que futuras consultas ao banco de tese da PUC contribuam para divulgar o autor.

\section{SYNOPSIS OF THE ODISSEY}

Originally, I had thought of preceding each book of the poem with a short "argument", as in Milton's Paradise Lost and Paradise Regained, but I feared that the reader might eventually come to think of these not as the translator's but as the poet's original synopsis. Inevitably, especially in the later and more philosophical books, even the slightest exposition of events involves much individual interpretation, and though I have often discussed every aspect of the poem with the author, I have thought it best to relegate the synopsis to this Appendix where it may be acknowledged clearly as the translator's and thus freer scope be given for those sections of the poem which will always remain open for philosophical or symbolical speculation. This synopsis is meant to assist the reader in obtaining a clearer perspective of the action, especially if he glances at the argument for each book before reading the book itself, and to help him systematize the philosophical thought entwined with richness of episode, metaphor, and parable. He will often find incidents described in such a way as to include and interpretation. This synopsis, however, is in no way to be thought of even as an abstract substitute for the poem itself, especially in those parts where the symbols and allegories take on varied significance for each reader, and where the thought is instinctively and inseparably part of the poetic texture. Perhaps this précis may also be of some use later to scholars who might wish to make the necessary exhaustive comparative studies or to research into derivate sources.

\section{PROLOGUE}

The poem, appropriately, both opens and closes with an invocation to the sun, for the imagery of fire and light dominates the poem and bathe it iridescently with symbolic meaning. The central theme is boldly announced:

O Sun, my quick coquetting eye, my red-haired hound, Sniff out all quarries that I love, give them swift chase, tell me all that you've seen on earth, all that you've heard, and I shall pass them through my entrail's secret forge till slowly, with profound caresses, play and laughter, stones, water, fire, and earth shall be transformed to spirit, and he mud-winged and heavy soul, freed of its flesh, shall like a flame serene ascend and fade in sun.

The sun symbolizes godhead, the ultimate purified spirit, for the central theme is the unceasing struggle which rages in animate an inanimate matter to burn away and cast off more and more of its dross until the rarefied spirit is gradually liberated and ascends toward its symbolical goal. Concomitant and contrapuntal themes are 
also announced: the laughed and joy that rise through and above tragedy; the freedom from all shackles which prudence and the comfortable virtues dictate, from all philosophical, ethical, and racial ties; the certainty that for each individual the phenomena of the universe are but the mind's creations. And from the beginning the poet strikes the tone which he maintains throughout: that of adventurous and dangerous exploration of both physical and spiritual worlds; a heroic, serious, yet ironic and playful braggadocio in the face annihilation; the accents and the rhythms of folk song, the tall tale, fable and myth; the passionate yet laughing play of the poet's imagination with his material as he casts off from all sure anchorage like a restless mariner and launches into a shoreless sea of no destination: "Ahoy, cast wretched sorrow off, prick up your ears---/ I sing the sufferings and the torments of renowned Odysseus!"

\section{BOOK I}

Odysseus subdues a revolt in Ithaca. In Book XXII of Homer's Odyssey, after Odysseus has killed the suitors of his wife with the aid of his son, Telemachus, his old nurse finds him amid the corpses "splattered with blood and filth, like a lion when he comes from feeding on some farmer's bullock... a fearsome spectacle." $\mathrm{He}$ forces twelve unfaithful maidservants to clean up the gory evidence of the massacre, then orders them strung up and hanged in the portico of the central courtyard. It is here that Kazantzakis has cut away Homer's last two books and grafted the opening of his sequel, for his own first book begins abruptly with an "And" as though he were continuing a previous sentence in Homer where Odysseus strides to his bath to cleanse his bloodstained body. Some incidents from Homer's last two books, as the tender recognition and reconciliation scene with his wife, Penelope, are entirely omitted; other incidents are reshaped, as the recapitulation of his adventures, the first meeting with his father, and the angry uprising of his own people. As the new Odyssey unfolds, still other incidents in Homer are reshaped or given another interpretation. The savage aspect of Odysseus terrifies Penelope, and he in turn feels nothing of the anticipated joy on beholding her. The windows of the men killed at Troy, and the fathers of the slain suitors, accompanied by the shades of the dead men, arouse the people to revolt and rush with torches toward the palace to burn it. Odysseus summons his son to help him put them down, speaks with contempt of both rabble and arrogant archons, and insists on the right of autocratic rule. But to Telemacus, a mild-mannered youth who wants nothing more than follow in traditional and conciliatory paths, his father now seems a stranger, harsh, cruel, and murderous. He wishes that this "savage butcher" had never returned from Troy. As they go to face the mob, Odysseus tells Telemachus of his meeting with Nausicaä and how he longed for her to become his son's bride. He then confronts the mob, and by pretending to think his people have rushed up to become him, subdues them craftily with specious promises, then cows them until they kiss his hand and follow him obsequiously to the palace. There he dismisses them, then joins frightened Penelope in bed. Telemachus dreams that his father, in the form of an eagle, seizes him by the skull, soars with him into the sky to test and strengthen his daring, then drops him headlong. Early next morning Odysseus explores his palace, taking an inventory of what the rapacious suitors have left, and nostalgically recalls some of his old adventures. He confers with his farmers about his fields, his cattle, his slaves, 
portions out jobs, sets his realm in order, then announces a great fest in honor of his return. Filling a jug with the suitors' blood, he climbs a mountain to his ancestral graveyard, pours out a libation that his forefathers may drink and revive, dances with them on their graves, then climbs to the mountain top and views his island lovingly. On his descent, he stops by a humble basket-weaver to beg some food. Though he does not reveal who he is, he tells the old man that Odysseus has returned, but the basket-weaver is uninterested in the fate of kings and concerns himself only with the simple needs of daily living, deplores ambition, and praises the common life, the proven verities, compliance to Death and Mother Earth. With arrogance, Odysseus upholds the life of individuality, revolt, and cunning, yet concedes that all life is vanity and that all roads are equally good. Odysseus father, Laertes, who all his life has been as much a farmer and landsman as his son has been a sailor and adventurer, crawls out to his beloved fields and calls out to Mother Earth to take him at last. At dusk all gather to the great feast of their king. Among the revelers is Centaur, a glutton and great drinker, broad-buttocked, barrel bellied, splay-footed, a mountain of meat, sentimental, softhearted, affectionate. His particular friend is Orpheus, a poetaster and piper, cricket-shanked, scraggly, crosseyed, dream-taken and timid. When the feast begins and all wait for their long-lost master to pour a libation to the gods, Odysseus shocks them by proposing a toast to man's dauntless mind. As the revelry progresses, the chief minstrel rises and sings of the three Fates which had blessed Odysseus in his candle: Tantalus who bequeathed him his own forever unsatisfied heart, Prometheus who gave him the mind's blazing brilliance, and Heracles who bathed him in the fire of the spirit's laborious struggle toward purification. Reminded of these bequests, Odysseus in fury lashes out at himself for wishing to settle down safely and seek no further paths to knowledge and exploration. He knows he has a more primitive atavistic ancestor in his blood. His confession frightens his people, and Telemachus once more curses a father who seems to be all that is contradictory, restless, and unappeased, revolutionary yet autocratic, atavistic and savage. Odysseus calms his heart by walking down the seashore at night.

\section{BOOK II}

Odysseus lives Ithaca forever. By the fireside the following night, Odysseus tells his father, his wife, and his son that on his voyages Death had approached him in three deadly guises. (I) With Calypso life had seemed a dream, and he had been tempted to accept her gift of immortal youth, but an oar cast up by the sea recalled him to life once more. He built a ship and sailed away, but when he came in sight of his native land, a storm swept him off, and in delirium he visited the gods on Olympus, who crowded about him to admire his mortal and aging body. (2) Shipwrecked on Circe's island., he was tempted to turn beast for love of her, to forget virtue and the spirit, and to wallow in fleshly delights, but one day the sight some fishermen, a mother and her baby enjoying the simple comforts of food and drink, recalled him to life, its duties and delights. (3) Again, he built a vessel, and again he was shipwrecked, but with Nausícaa he was tempted to lead a normal, unassuming life, the sweetest of all the masks of death. Although he abandoned Nausícaa also, he was determined to fetch her one day to be his son's bride that she 
might breed him grandsons. When Odysseus finishes his tale, he realizes suddenly that this own native land is the most lethal mask of death, a confining prison with an aging wife and a prudent son.

Soon after, his father, Laertes, feeling the approach of death, crawls with his old nurse at daybreak to his orchard, bids his trees, his birds and beasts farewell, sows grain, then falls to earth himself like seed, and dies. Odysseus buries his father, then sends a ship with a great dowry to fetch Nausícaa for his son. His island seems to him a strange place now, for a new generation flourishes, and the town elders, with whom he had longed to confer, seem rotting, senile, timid. Odysseus decides to leave Ithaca forever. Several months later, in autumn, he finds Captain Clam, a grizzly and trustworthy old sea-wolf, and persuades him to leave also. Next, he visits the bronzesmith, Hardihood, a red-haired, burly man from the mountains, sullen, secluded, with a stain like that of an Octopus on his right cheek, and enlists his aid by promising to lead him to the god Iron, a superior metal. A few days later, he finds Centaur drunk in the middle of a road and takes him also. Working by day and carousing by night, the four companions begin to build their vessel. Orpheus is attracted by their food and revelry, and Odysseus takes him on as a crew member to comfort them as times with a song. The townspeople, fearing that all five men are demon-driven, persuade sorceresses to make a manikin in the shape of Odysseus, hammer it with nails and then cast it in sea, but when Odysseus finds it, he laughs and throws it in campfire for kindling. One day a strander joins them, Granite, a brooding young man of noble fearing, a mountaineer of good family, who had killed his young brother over a man and now roams restlessly, burdened with guilt.

Meanwhile, the various women with whom Odysseus slept on his voyages hear his return and send him all his bastard sons and daughters. He puts them to work, deeply moved by one of them only, his daughter by Calypso. Telemachus and a representative of his people, a man who had lost his arms at Troy, plot to kill Odysseus. In the summer, Nausicaä comes at last in her bridal ship, and the wedding with Telemachus is celebrated. A minstrel sings of Crete and of her cruel, military god, most suited to Odysseus' temperament. During the wedding feast, Odysseus discerns preparations to made kill him, confronts his son at once, yet rejoices to see him such manliness and revolt. He promises to leave Ithaca the next morning, and that night, with his companions, loots his own palace with food and weapons, then leaves with dawn without saying goodbye to his son or wife. The friends launch their ship and set sail for unknown destinations.

\section{BOOK III}

Odysseus goes to Sparta. To while away the time as they row and sail, Orpheus tells a story of a male and female worm, representative of man's stubborn spirit, who find ways of overcoming God's attempts to kill them by fire, hunger, flood, and death. At the same that Helen, in Sparta, is filled with ennui and longs to be abducted once more, Odysseus dreams of her calling him for help, her armpits dripping with blood. He wakes up, startled, and directs his crew to make for Sparta. Completing the story of the two worms, he recounts how they had settled in a far northern village which God had partly destroyed by a meteor, and how one day the male worm had smelted the ore, discovered iron, then matched his iron, sword with 
the copper sword of God and had slain that old decrepit man in heaven. Thus, Odysseus implies, will the lowly barbarians with their new iron weapons conquer the decadent bronze civilizations. The companions now sight land, stop food and water, then after three more days disembark near Sparta. As a present for Helen, Odysseus chooses a magic crystal ball given him by Calypso, takes Centaur with him, steals a chariot and horses, and makes for the capital. He considers how Helen has never been for him a carnal temptation but has always inspired him to the high valor of the mind. As they ride along the Eurotas at harvest time, they encounter members of the barbaric blond Doric tribe who have been descending into Greece from the far north, and who symbolize for the Kazantzakis the new savage blood which is to revive the now decadent Greek civilizations, first by destruction and then by intermarriage. Odysseus rejoices that he was born in a time of upheaval and transition between shifting cultures and new worlds.

As they sight Mt. Taïgetus, the fivefingered mountain which looms above Sparta, Odysseus suddenly realizes that he has come here with the hope of convincing Helen to run off with him on new adventures. Stopping by a roadway shrine to Aphrodite, he prays that his wish may be granted. When they arrive by nightfall at

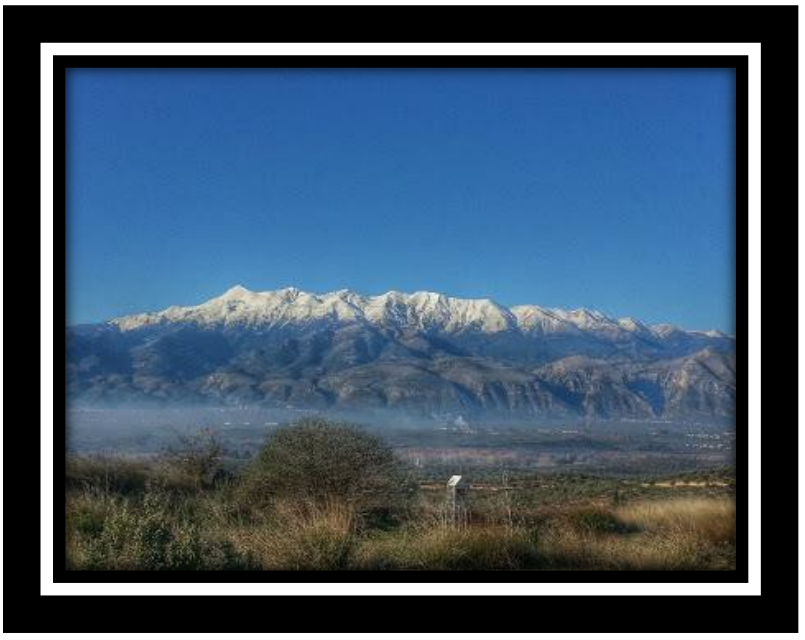

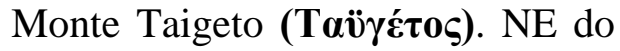
Peloponeso, Esparta. Menelaus' castle, they find the hungry peasants in revolt because their king has been confiscating most of harvest, but as they are about to attack, Odysseus suddenly leaps before them and frightens them into storing all their harvest in the castle by saying that they are in danger of attack by the blond Doric barbarians. When Menelaus has at last guessed who this stranger must be, he cannot find him, for Odysseus has penetrated into the dark halls of the castle to seek Helen. When they meet, both are deeply moved, and recall the past glories of the Trojan war. At supper that evening, Odysseus is scornful on Menelaus' soft life, and warns him that the barbarians will find him an easy prey, but Menelaus defends the comforts of old age. Odysseus speaks of the new god, barbarous and savage, who is rising now to replace the civilized gods of Mount Olympus and feels himself disturbed in sympathy with the destruction this new god symbolizes. When they part for the night, he presents Helen with the crystal ball.

Unable to sleep, Odysseus roams the palace and bids farewell to vested wealth and comfort. An obscure reaction has been fermenting within him against his own aristocratic class, and an awakening sympathy with the hungry workers, the Doric barbarians (symbolic of periodic primitive powers that destroy decadence and sow the seeds for other cultures). Centaur explains to the slaves that by the new god Odysseus means the new metal, iron, which the barbarians have brought with them and which will soon destroy the old gods and civilizations based on bronze. After Odysseus helps drunken Centaur to bed, he feels a sudden love and compassion for 
all mankind, and envisages the earth slowly distilling all phenomena to the pure honey of the spirit.

\section{BOOK IV}

The second abduction of Helen. Menelaus dreams that he is riding with Odysseus through scenes of contentment, but that his friend proffers him the sword of contention. On awakening, Menelaus rides out with Odysseus to show off his lands and wealth, assures the villagers that they are safe from attack by the barbarians, and orders the young men to prepare games of skill with which to entertain their guest that evening. They pass through summer harvests, watch straggling tribes of blond barbarians gleaning what poor scraps remain, and rest in olive groves where for the last time Odysseus fries to persuade Menelaus to accompany him on new adventures; but when he sees that his friend is concerned only with the comfortable virtues, with profit and loss, he fiercely decides to abduct Helen. They continue their ride to the upland pastures of Mt. Taigetus where Odysseus admires the brave young shepherd, Rocky, who has climbed the high mountain crags to kill the marauding eagles that have been stealing his lambs. Odysseus requests and receives the shepherd lad as the sixth and last member of his crew, though Rocky goes with him reluctantly. Menelaus believes that a man should follow whatever fate has ordained for him, but Odysseus replies that it is man's duty to fight his fate, surpass his doom, and even his god. Meanwhile Helen, with her retinue of Trojan slaves, laments the destruction of Troy, and in her crystal ball sees a preview of her flight with Odysseus, and a glimpse of Knossos ${ }^{34}$.

The two friends return with Rocky to the castle, and as Menelaus bathes, Helen tells Odysseus that she has resolved to leave with him. They plan to steal off together the next morning. That evening the aristocratic youths, the workers' sons, and the bastards spawned on the Spartan women by the blond barbarians, dance in the palestra to entertain their guest. The workers' sons perform a dance of harvesting which is wrathfully stopped by Menelaus as it quickly turns into a rebellious hacking for freedom. The young men of the aristocracy dance with a harmonious restraint and proportion admired by Menelaus, but scorned by Odysseus who sees them lacking in tragic awareness of the spirit's and body's strife. Then the bastard sons rush into the arena in a mock battle which swiftly turns real until blood flows. Menelaus stops them in rage and rises to present the wild olive wreath to the youths of the nobility, but Odysseus snatches the spray and presents it to the bastards, indicating thus his contempt both for the ineffective poor and the elegant rich, and his preference for the outlaw virtues, the illegitimate and lawless, that which destroys traditions and smashes frontiers. He declares that only the strong have the right to rule, At the castle gate, representatives of the blond barbarians request permission from Menelaus to settle in his land, and when Menelaus grants their request in fear, Odysseus with scorn sees that this is the inevitable conquest of decadence by virility. At the farewell feast that night, although he is planning to

\footnotetext{
${ }^{34}$ Sede da civilização cretense, cujo apogeu vai, aproximadamente, de 1.600 a.C. e 1.100 a.C. Os cretenses constituíram uma civilização brilhante, centralizada no Palácio de Knossos. Vencidos pelos micênicos, sobrepujaram culturalmente os vencedores, influenciando-os e sofisticando-os. O período creto-micênico foi o celeiro da tradição heroica que serviu de matéria prima para os poemas homéricos.
} 
betray his friend by stealing his wife, Odysseus - half in genuine sorrow and half in cunning - speaks of his great love for Menelaus and of his sorrow at parting, and Menelaus sentimentally moved, gives his friend a god statue of Zeus, the god of friendship. Odysseus vows eternal friendship, but when his friend falls into a drunken sleep, offers Helen new adventures paths of danger and strife, and rejoices when Helen, though afraid of his cunning and savagery accepts freely. Meanwhile, Kentaur advises Rocky like a good friend, consoles him of dangerous yet alluring life all lead who follow the unpredictable archer. In a dream that night, Odysseus has a vision of Zeus as a wrathful god of friendship betrayed, but dismisses all the Olympian gods as figments of men's hearts and fears. When day breaks, the three steal a chariot and make off with Helen.

\section{BOOK V}

Arrival in Crete. At nightfall of that same day, they reach the rest of the crew, and swiftly set sail, though toward no certain destination, inspired by Helen's presence. A fierce storm blows for three days and finally smashes their rudder. Concerned for Helen only, Odysseus curses a baleful and murderous god. In cowardly fear, Orpheus whines that God is demanding a sacrifice in expiation for the abduction of Helen, but though Hardihood approaches to cast her into the waves, he finds that he cannot, overwhelmed by her beauty. Odysseus rejoices at his manliness and declares that he will make Hardihood king of the first land they sight. Almost immediately, the storm subsides, and Crete is sighted, a land of great wealth, but now in its decadence.

They land in the harbor near Knossos, fall into a tired sleep, then wake next day at noon. Odysseus sells the golden god of friendship for food and clothing, the crew members scatter throughout the colorful port, and Helen and Odysseus meet a peddler who tells them they have arrived on a holy feast day when their senile king, Idomeneus, Odysseus' old companion at Troy, is climbing holy Mt. Dicte ${ }^{35}$ to commune in a cave with the priestess of the Bull-God and thus regain his virility that his people and land might once more become fertile. (Throughout his poem, Kazantzakis has taken many incidents and symbols from Frazer's The Golden Bough, as here the fertility rites and rituals of primitive peoples.) The peddler sells Odysseus an ivory god of seven heads: the first is bestial, the second is savagely martial, the third voluptuous, the fourth represents the flowering mind, the fifth tragic sorrow, the sixth a serenity beyond joy and sorrow, and the seventh the ethereal soul. For the first time, Odysseus is deeply moved by the prescience of the gradual purification his vision of God must undergo, from the pure beast to the pure spirit.

Leaving Captain Clam, Centaur, Granite, Rocky, and Orpheus in the harbor to repair their ship and to keep watch, Odysseus joins a stream of pilgrims and mounts toward Knossos with Helen and Hardihood in a hired cart. Their tells them of the

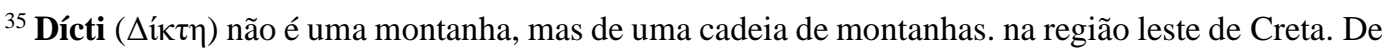
acordo com a mitologia, Zeus foi criado ali, em uma caverna chamada Diktaion Antron (caverna de Psicro, no planalto de Lasíti), no Monte Ida, o ponto mais alto da cadeia. A topografia da cadeia é rica em planaltos, vales e picos secundários. Grande parte da zona montanhosa são florestas. Os vales férteis e planaltos de Dícti, desde priscas eras, tinham importância significativa para a economia local.
} 
bull rituals soon to be celebrated. The blond barbarian gardener, who gives Helen a drink of water on their way up, is the one who will later become her husband, symbolizing the merging of archaic and savage blood to produce the new coming ('classic" race. They reach the palace and find it being decked with lilies and palms by the Serpent Sisters, priestesses of Mother Earth. Amid leopards and her three Negro lovers, Diktena appears for a moment, the second daughter of the king, the priestess of the holy temple harlots. As Odysseus goes to announce their arrival, confident of an immediate welcome, the blond gardener suddenly appears and silently offers Helen a cluster of grapes, then vanishes. Odysseus returns, furious at his repulsion by the palace guards, and all three sleep with the other pilgrims on the courtyard tiles.

Early next dawn, the Serpent Sisters supplicate Mother Earth in dance to fructify their king, and t us all of Crete, but their dance is suddenly interrupted by Phida, the eldest daughter of the king, who hates her father's decadent realm and plans an uprising with the slaves and her group of dedicated women, the Rebels. She falls screaming in an epileptic seizure, but when Odysseus rushes to her aid, the palace eunuchs suddenly rush out and take her away.

Meanwhile, old King Idomeneus has crawled into the holy stalactitic cavern on Mt. Dicte where priestesses masked like cows surround him, as from a hollow bronze bull the high priestess of the Mother Goddess arises, and the sham ritual begins. King and priestess come to an understanding whereby he gives her property and gold in exchange for a nine-year blessing of fertility and strength. The news is blazoned by beacons from mountain peak to peak until it reaches the palace and town where the people spread their garments on the streets that their king may pass upon them and impart to them his new virility. When on his return Idomeneus is told that his youngest and virgin daughter, Krino, has not been caught to be his incestuous bride in the bull ritual, he orders that the men sent to catch her should be put to death. Krino is the leader of a virgin band of Mountain Maidens who in the sacred ritual oppose the Holy Harlots led by Diktena.

After being made to wait ignominiously, Odysseus and Helen are admitted to the king's presence and his decadent inner court. Idomeneus resolves to make Helen his ritual bride and to kill Odysseus, because his presence anywhere always spells disaster, but when Helen refuses unless Odysseus is spared, the king consents, though forebodingly, then commands the Serpent Sisters to prepare his bride in seven days and nights for the holy bull ritual.

\section{BOOK VI}

The bull rituals at Knossos. Seven days later, at cock crow, the Serpent Sisters entreat their Bull-God to descend and fertilize the earth and their people. The bull arena quickly fills, the common people crowd in the upper tiers, the painted lords and ladies of the court sit below. Though Odysseus gazes on all with loathing, he still marvels at any manifestation of mysterious and brief life. When the sun rises, the King appears wearing the mask of a black bull with golden horns, mounts his throne, and signals for the games to start. In the center of the arena, on a 'White bull's hide, Helen lies, naked, beside a hollow bronze cow. As a herd of trained bulls is let loose in the arena, Helen calls out, in ritual, to be saved from the Bull-God, but Diktena and her Holy Harlots exhort her to submit. Krino defends the body as 
a chaste and pure instrument of God, and Diktena as flesh to be offered him in sacrificial and lustful rites.

As the pre-rituals end, and the Holy Harlots scatter amorously amid the archons, we are given glimpses of the hard lot of the slaves in contrast to the lustful decadence of the court. The King signals again, seven bulls are loosed in the arena, and the famous acrobatic dancing and somersaulting begin, led by Krino. Further scenes of poverty and oppression in Crete are shown; at noon, as a thresher and his wife eat their scant food in the fields, the King orders the games stopped and the feast spread. The slaves scurry to prepare and serve the meals; a slave mother rushes with her baby into the sunlit court from her dark dungeon and finds that it is deadonly Odysseus hears her scream, and feels that he is responsible for all the pain on earth, as if he were earth's only savior. Gradually in Odysseus an almost Christian consciousness of the world's suffering is being awakened, and a sense of responsibility toward pain and oppression. He is dazed by the rot and stench of the civilization around him. At this moment, Diktena claims him for her partner in the orgies to be held that night, and Odysseus resolves, to Hardihood's disgust, not to spare himself anything of degradation, knowing that a strong soul cannot be soiled.

Meanwhile, in the arena, Krino has been strangely drawn by Helen's beauty; the two women kiss and caress each other in the burning sun until Idomeneus, enraged by jealousy, orders Krino to play with the fiercest bull of all, who has secretly been fed irritating and intoxicating herbs. Although she knows that she is going to her death, Krino plays acrobatically with the bull, is suddenly gored, tossed high in the air, then falls impaled on the double-ax standard of the Bull-God. It is now twilight. The thresher and his wife have gone home, the slave mother buries her child, and the Serpent Sisters escort the common people out of the arena so that the orgiastic secret rituals of the nobility may begin.

At the full moon, the lords and ladies of the court don the hides and masks of various animals, the Serpent Sisters raise Helen and place her in the hollow bronze cow, and as the King slowly approaches, a bull is slain, and all fall upon it and eat it raw. As Idomeneus steps into the bronze cow, the lords and ladies engage in orgiastic lust throughout the arena, Diktena stuffs Odysseus' mouth with the bull's loins, and both fall into an erotic embrace. Suddenly Phida appears, shrieking, flies to where Krino lies impaled, and receives the dripping blood on her outstretched arms until her enraged father orders her driven out of the arena at spear's point.

Meanwhile, the five crew members have been drinking in a harbor tavern where Captain Clam tells them of secret arrangements he has made with the blond barbarians who are now setting sail for their native land to bring reinforcements. As the decadent nobility feast through the night, Hardihood comes and reports to Odysseus that in his wanderings through the labyrinthine palace cellars he had discovered a secret forge where a captive barbarian was forging weapons of iron for Idomeneus. Phida had suddenly appeared and given herself to the ironsmith in ee change for iron weapons promised her and her Rebels.

At early dawn, the slaves come to gather their drunken lords and ladies, and the blond gardener again appears suddenly and makes off with Helen. As the Mountain Maidens wash and bury Krino, Phida and her troop of Rebels sing and dance songs of poverty, oppression, and revenge until Odysseus, deeply moved by all he has seen and done, joins her in a dance and song of slaughter and rebellion. Phida falls 
into a paralytic swoon, and her Rebels take her away. Unable to sleep, Odysseus lies by the riverbank and listens to a slave singing of freedom. Finally, as he drowses and falls asleep, his old companion, Death, makes the first of his many appearances, lies beside him in comradely embrace, and the two sleep together. For a brief moment Death, also, falls asleep and dreams of life.

\section{BOOK VII}

The conspiracy to destroy Knossos. In his sleep, Odysseus dreams of Fate in the form of a woman who stabs him with three knives, with three great experiences and adventures in life: woman in youth, war and glory in manhood, and death in old age. At sunset Hardihood and Odysseus watch the decadent lords and ladies strolling by the riverbank and mark them down for slaughter. For three days and nights Odysseus broods in agonized silence on the projected destruction and massacre of Knossos, and calls on his God for help, but the god that finally appears is a tearful and frightened likeness of Odysseus himself. Odysseus' image of God is to change, gradually, from a timid god to a god of battle. Realizing that it is God, not he, who needs assistance, Odysseus dismisses him in scorn, but tells Hardihood that he has had a vision of a savage and flaming god of heroic proportions.

As she lies beside the senile King, Helen reminisces of her Trojan days, recalls her escapade with the blond gardener, then gazes into her crystal ball and sees herself married to the gardener and living with their son in tents. Odysseus disguises himself, and assisted by Phida, who urges him to join her revolt, visits Helen in the women's quarters. He mocks Helen for her affair with the gardener, but when she asserts her free will to choose her own destiny, Odysseus rejoices, as always, when anyone shows a will equal to his and takes another road. He unfolds to Helen his plan for the sacking of Knossos, enlists her aid, then leaves for the harbor town. There he finds his friends carousing in a tavern and tells them of a new god he has seen who is not compassionate, but wrathful and unsated. He then assigns to each his role in the uprising and informs Captain Clam that he is to remain in the port to assist the incoming barbarians and to fire the arsenal.

As summer passes, Odysseus consults with Phida, Hardihood helps the blond ironsmith forge weapons, and the barbarian ships sail for Crete from the far north. Winter passes, the plot progresses. Odysseus works with a slave, a skilled woodcarver (much like Daedalus) who studies the flights of birds and longs for freedom. When spring comes, Idomeneus has a premonition of his death. Helen, pregnant with the gardener's child, has forgotten Sparta and Troy, stitches her baby's swaddling clothes, and dreams of her son. Odysseus tries to rouse the slaves by lying, once more, about his vision of a flaming god, a fierce warrior and ruthless hunter. Although he longs now to help the workers, he is under no illusion, for he knows that slaves want that which their lords already have; then he feels that God is working out his liberation through medium of these oppressed bodies, and that this is the step toward the purification of spirit in an endless strife to the world's end.

After a sleepless night before the day of a great holy festival, Idomeneus paces restlessly at dawn, filled with nightmares and destruction. Odysseus and his friends are preparing the massacre. Dressed in a mantle adorned with marine figures, the King is symbolically wed in a spring ritual with the sea. As Odysseus walks along 
the river toward the harbor and a young boy and girl proffer him flowers, he is seized with pity that even such innocents must perish in the general massacre, but when he sees his god hovering near him in the form of a pitiless vulture he steels his heart. He learns that in the holocaust of old values, many who are innocent and blameless, or simply victims of circumstance, of heredity and environment, must also perish. He plays with Captain Clam on the beach and in the sea, for both feel that the old sea-wolf is fated to perish when he fires the arsenal. Idomeneus is wedded to the sea, and faints. The palace is decorated for the festival, all the conspirators take their allotted stations, the barbarian ships secretly approach the harbor, and the plotters prepare for the massacre.

\section{BOOK VIII}

The destruction of Knossos. That night a slave girl, whom the archons had forced to dance until she died, is buried by Odysseus and his friends. Even Orpheus is moved to vows of vengeance. Odysseus tells the ironsmith that the night has come to distribute the iron weapons. In the palace amid great feasting, Idomeneus looks on pregnant Helen with pride, thinking she is bearing his son. Odysseus and his vulture god crouch in darkness by a column and observe the feast at the exact moment when Captain Clam is creeping into the arsenal to set it on fire. Idomeneus, and even the palace walls and adornments, sense with terror the coming destruction. At midnight, when his god nods approval, Odysseus suddenly rises and, to the fluting of Orpheus, sings of unslaked fierceness, of cunning deception, until a messenger enters in haste and shouts that the arsenal is on fire. Odysseus then gives the signal, and the massacre begins. Just as Odysseus is about to slay Idomeneus, Phida intervenes and beheads her father with a double ax but is in turn killed by one of the Negro guards and falls on her father's corpse. Phida's Rebels and the barbarians sack the palace and set it on fire; the blond gardener makes off with Helen. Through the smoke and flames, Odysseus catches sight of the woodcarver flying away on constructed wings.

After the massacre and the burning, Odysseus proclaims Hardihood King of Crete, as he had promised during the storm. At dawn, as the vultures, crows, and dogs eat the corpses, the victors broil meat on the embers of the still-smoldering palace, and fall to carousing, but Odysseus withdraws to a high rock and spurns both food and women. Toward sunset, a delegation of townsmen come with gifts to plead for mercy and peace, but Odysseus again scorns all the virtues that appertain to peace and comfort and instead proclaims war and death. When at last he takes some bread to eat, he spies a green locust perched upon it like a green Death, and for the first time feels fear. I-le falls asleep and dreams of the ravenous Spirit, eating him whole like an octopus, consuming the flesh in order to live, making man ever discontent and humble before greater deeds to be done. He then joins his companions and tells them they have accomplished nothing. He tells them a fable of how God created the world and all living creatures, then called on all to bow in reverence, but how the human heart refused to bow or surrender its freedom. Ever since then, a war has raged between what God destroys and what the unsated human heart rebuilds. Odysseus dashes to his feet, eager to follow his heart at once to further and higher adventure. He advises Hardihood to begin his rule, but when Hardihood says that he has already sent runners throughout the land, Odysseus rejoices to see that 
another spirit has proclaimed its freedom from him and formed its own independence. "The sweetest fruit of all that ripened on this day/is that one soul has found its freedom and cast me off!"

Next morning all gather to bury Captain Clam and Phida side by side. Odysseus declares that God is a blind dark power seeking to evolve through nature till human beings give him senses and a soul. Helen then appears with her gardener, and Odysseus begins his farewell. He advises Hardihood to rule with merciless love, with force and patience, to free the slaves, to portion out the land, to be forever unsatisfied, and to break through what may seem to be impossible frontiers, for he fears that Hardihood, like most men, will freeze into the forms of comfortable virtues once he settles down and cultivates his own possessions. He bids Helen farewell, then leaves without looking back.

Taking Diktena with them, the comrades now sail southward, and on the fourth day, as Crete disappears and Odysseus bids Greece farewell forever, he rejoices to leave behind all sureties and to sail toward unknown creations and freedom. Diktena sings of how she had been sent as a twelve-year-old girl to give of her virginity to an unknown Egyptian god. Odysseus tells his crew that he derives his strength and courage from the knowledge that all life is a brief dream, a toy, and when Granite replies that it would be best then to commit suicide, Odysseus retorts that he is the creator of his own dreams, that he both serves and drinks his own blood, that he accepts necessity with joy, At dusk one day, they moor near the mouth of the Nile, and Odysseus tells his crew a fable about a grandfather, a son, and a grandson who rowed all their lives long to find the still unknown source of the Nile, the fountain source that would bequeath immortality, though all died on the way. Odysseus then declares that blessed are those eyes that have seen more water than any man," that the hidden deathless sources may be found in Death only. Rocky objects that the presence of Diktena among them is distracting, that she is useless ü-ld Odysseus agrees to leave her behind.

\section{BOOK IX}

The decadent empire of the Egyptians. Next morning the friends all walk down to the harbor town, delighting in a strange new race of men. As they drink in a harbor tavern, Odysseus feels dark, atavistic roots, as though he had sailed these waters in another life long past. An old blind bard sings to them of pain and poverty, but Odysseus refuses him food because he feels that in this land Hunger is the herald that will lead him to his new god, and that to feed one mouth is to feed none. The friends abandon Diktena to her willing fate on the harbor's docks, and sail the Nile. Odysseus urges his crew to row toward Thebes, about which Helen had once spoken. After many days, they anchor by a ghost town of ruins, tombstones, and gods with animal heads. Odysseus realizes that beast and have always waned in man, as the spirit sought to evolve into light through dark atavistic roots. He knows now that his ultimate destination is to free God as far as possible from the beast, toward more and more salvation. One day the friends find a huge stone Sphinx, and an old Egyptian trying to free it from the encroaching sand. Accepting the old man's invitation, they go to his house for a humble meal and are served by his two young daughters who sing to them of love, yearning, a home and children. All feel the 
strong attraction of hearth and home, Rocky most of all, but they all reject it for the insatiable and faithless heart.

As they continue to sail down the Nile, they plunder and steal in order to live, for everywhere they find drought, hunger, and extreme poverty. One night they anchor in the ruined Sun City, Heliopolis ${ }^{36}$, where Odysseus dreams of a tomb and of a king and queen (Ikhnaton and Nefertiti) who beg him to unearth them. They dig at midnight, find a tomb of a king and queen laden with treasure, strip it, then load their skiff until it almost sinks with gold and jewels, and continue their journey. But their hearts are heavily laden, for now all long to settle down in comfort and pleasure, until Odysseus suddenly grasps fistfuls of the treasure and begins to fling it overboard. All follow suit until not even Orpheus' ivory flute is spared.

They sail now with free hearts, but hear everywhere laments of hunger and starvation. As Orpheus wonders how Helen is faring, we see her in Crete, maternal and content with her newborn son. Kentaur pities he starving Egyptians, especially the children, but Odysseus replies that Hunger and War are two powerful drives which force men to push further on in their exploration of the world's limits: "If I could choose what gods to carry on all my ships,/l'd choose both War and Hunger, that fierce, fruitful pair!" After many days, they anchor toward nightfall at Thebes, a bustling crowded fortress smelling of evil. The Pharaoh is a world-weary, timid youth overshadowed by the remembrance of his grandfather, a great warrior. $\mathrm{He}$ has no other ambition than to finish a lyric which he writes and rewrites laboriously. The friends roam the streets all night, gazing on the pampered lords and the seductive ladies until at dawn they fall asleep on their deck and dream of food. When they awake, they all disperse to seek food, but only Centaur succeeds somewhat, for he finds a young whore who invites him to share her scanty meal. Next dawn, when they are all still hungry, Odysseus reminds them that he had never promised them either women or food, "but only Hunger, Thirst, and God, these three great joys." Then he tells his comrades that he will leave by himself to seek some kind of solution, and that if he does not return in three days, they are to shift for themselves.

\section{BOOK X}

Rebellion in Egypt. Led by Rala, a young Jewess, the people rise in revolt against the decadent priests and their crocodile god and storm the temple. Odysseus, swept by the onrush, tries to save Rala, but suffers a severe head wound. They are both thrown in Pharaoh's dungeon, and there Rala and three other revolutionariesScarab, Nile, and Hawkeye - tend him anxiously for three days. (Meanwhile, Rocky and Granite have abandoned their skiff, Rocky going south and Granite north, but Centaur and Orpheus remain.) In a coma, Odysseus sees his son, Telemachus, out hunting, and Nausicaä on her terrace eating figs. After six days he finally opens his eyes, and Rala faints from weariness. The three revolutionaries try

\footnotetext{
${ }^{36}$ Os gregos antigos chamaram Heliópolis à cidade egípcia de Iunu ou Iunet Mehet (do egípcio antigo, "O Pilar" ou "Pilar do Norte"). Capital do XIII nomo do Baixo Egito, foi uma das cidades mais notáveis do ponto do vista religioso e político, durante o Reino Antigo. Situa-se a cerca de 10 $\mathrm{km}$ a noroeste da atual cidade do Cairo. A cidade mereceu grandes projetos de construção nos Impérios Antigo e Médio. Hoje está praticamente destruída. O deus solar Rá foi adorado no principal templo da cidade.
} 
to question him, but when they elicit no information, curse the exploited man who will not rise in revolt. Hawkeye is lean and volatile, as restless as fire; Scarab is somber, suspicious, a peasant close to earth; Nile is intelligent and reasonable, like smokeless light. Hawkeye invites Odysseus to join them in their revolt against hunger and exploitation. Odysseus recognizes in Rala the type of dedicated idealist who sacrifices dreams of husband and home for an abstract cause. Then the three revolutionaries quarrel about Odysseus; Scarab believes he is an opportunist, a cunning shipowner who longs for profits only; Hawkeye believes he is a Cretan of hidden powers; and Nile believes they are both right, that Odysseus is probably one who comes from the upper classes but who likes to play with fire, and advises his two comrades to accept him for what he is.

Next day Nile reveals to Odysseus how the workers in Egypt have been organized, and how they are all awaiting reinforcements by ship from the armed barbarians, the Dorians. Odysseus replies that he does not know whether he loves the bestial peasant or whether he simply no longer wants to side with the decadent nobles, but that a cry in his heart urges him to join the revolutionaries. This he will do, although he deeply feels that he belongs to neither side. His ambivalence disturbs the revolutionary leaders, but Nile tells him they will accept him on his own terms, no matter if he joins "from love or raging fury or search for God." Odysseus then dreams of God as a general recruiting an army, who, when he recognizes the dangerous ambivalence, the double-faced betrayal of Odysseus, advises him to act as purveyor for both sides.

Pharaoh, laboriously composing his lyric at his bath, commands that Rala and Odysseus are to be brought before him for amusement, then mocks Rala as a representative of a cursed race, whines that he is a man of peace who simply wants to keep the status quo, and that God has created some rich and others poor, but Rala declares she acknowledges one God only: man's free mind. Odysseus warns Pharaoh that a new race of barbarians is inundating his land, announces the doom of Egypt's ruling classes, then as a sign of war places on the king's knee a dwarfish god he had shaped in prison out of bread, blood, and sweat. This is now Odysseus' image of God, the god born of Hunger and Oppression. In terror, Pharaoh directs that Rala and Odysseus be set free.

Rala takes Odysseus to a secret meeting of revolutionaries where they hear news of approaching barbarian reinforcements. Rala advises an im-mediate attack, but Odysseus cautions against hope and says that he fights without either gods or hope. Returning to his skiff, Odysseus finds Centaur and Orpheus still awaiting him, but he admires and Granite who have asserted their freedom and gone off to shape their own fates, When he tells his friends of his adventures and of his desire now to join the revolutionaries, Orpheus mocks him for sentimentally swerving from his determination to find the source of the Nile.

Meanwhile, the barbarians have landed and begun to plunder the land. Pharaoh sends them emissaries who try ineffectually to frighten them off with words, magic, and their bestial gods, but the barbarians answer with a savage dance and song about a king who gets drunk, smashes an image of God, and then drinks from the hollow skull. The three leaders escape from jail, and Rala, tormented by her love for Odysseus because she feels she has thus betrayed her cause, bathes, puts on her best garment, then waits by the crossroads where the Egyptian army is to pass, 
determined to commit suicide. Odysseus tells his two crew companions that his mind and heart are opposed, for his mind wants to build an ivory tower of retreat, and his heart wants to knock on every door and share in every suffering; he prevents them from killing each other by making his mind a court fool to mock his heart, and by giving his heart the restrained freedom of a falcon. This ambivalence and tension in Odysseus between two opposites is the central key to his character.

\section{BOOK XI}

Revolution and defeat in Egypt. Both sides prepare tumultuously for war on Egypt's sands. On the morning of the battle, Granite appears with some barbarian hordes whom he had joined as they landed in Egypt, but he tells Odysseus they have been weakened by excessive plundering and carousing. Odysseus sees in the barbarians the new blood that will revive the rotted culture of the Egyptians, and he knows now that his purpose is to give direction to their savage onrush. As the Egyptian army passes, Rala hurls herself before the horses and is trampled to death. When Odysseus sees the endless Egyptian host, he realizes that there is no hope of winning, but elects to fight exactly because of this.

The barbarians and revolutionaries attack at midnight, but before dawn they are entirely routed, and the four friends lie on the battlefield, seriously wounded. At noon the king's herald passes among the dead and wounded to fetch the mightiest chiefs for the kino's amusement and sacrifice, and by several ruses Odysseus manages to have all his friends carted away. They lie in dungeons till past springtime. To amuse his friends, Odysseus carves out the twelve Olympian gods into marionettes pulled by strings. Nile retorts that the mind which mocks at gods is a god's slave still. But Odysseus has slowly been creating a new image of God, one who has nothing to do with justice or virtue, but is best represented by a hungry flame, an arrow constantly mounting upward. He dreams of a shape, either man or beast, which slowly tries to raise the Pressing sky from earth, helped by animals, birds, insects, and by himself. For three days and nights he tries to carve out the features of his new god, but to his disgust carves only a replica of his own features, for God is always created in the present image and evolutionary development of man. Nile mocks, but Odysseus declares against those who seek economic comforts only and declares that he serves an inhuman flame which burns within him and which he has named God. After a third dreamless night, Odysseus carves a savage mask of his new god which his friends immediately recognize as War and the barbarians as their own fierce god. Odysseus names him the God of Vengeance.

Pharaoh resolves to kill the rebel chiefs on his ancestor's great feast day as sacrifice, and when he allows them a last orgy, the friends confront death with varied emotions. But Pharaoh is in the grip of a nightmare he had seen the previous night, of a savage and monstrous head that rose above the horizon, a dangling corpse. No pleasure can console him, no dream interpreter eases him. Meanwhile, in his dungeon, Odysseus recalls a visit he had made with Rala to the embalmers and rejoices to remember that on the walls of the tombs they had painted a devouring flame that flashed beyond all comforts of life and nature, even beyond the gods. Recalling how a conjurer once tried to blow spirit into the mouth of a hawk-faced god, Odysseus knows that it is man who gives life to gods. Pharaoh's chief steward visits the prisoners and offers reprieve to anyone who can exorcise the king's evil 
dream. Odysseus offers to interpret the king's dream in dance. With the mask of his newly carved god dangling down his back, he dances of beggary, of war, of the maimed and wounded, then suddenly clamps the mask on his face. Pharaoh shrieks with terror, recognizing the terrifying face of his nightmare, then commands his guards to escort Odysseus and his troop out of the land. Odysseus returns to the dungeon, tells his troop of the glad news, eager now to leave Egypt, to lead his people to a new land and there build a city and civilization based on his new vision of God. Nile offers to follow them to the frontier but declares that he will remain in his native land to foment rebellion.

\section{BOOK XII}

The flight out of Egypt. Odysseus' troops are composed of the despairing, the criminal, the riffraff of life, that disruptive element which most often breaks down old values and treks toward new frontiers. When they reach the frontier, he holds up the mask of his god and asks all to choose between the poor comforts of their slavish existence and this new god who offers only thirst, hunger, and freedom. He wants only the unregenerated, the restless, the unappeased to come with him. In a dance of delirium, Odysseus declares that God has revealed to him the new road and the new city they must build, then divides the group into three troops, Orpheus precedes with his flute, Granite leads the youths and the amazon-like maidens, Centaur the old and the children, and Odysseus men in the prime of life.

For three days they follow the Nile amid crocodiles, snakes, and mud villages till they reach the desert sands. As they penetrate further and further into the desert's throat, they pass a human skull filled with bees, a last blade of green grass, huge carved rocks of a past sand-smothered civilization until, weak with hunger and thirst, they clamor to return, even though to slavery and poverty. Granite is ruthless, but Odysseus understands man's frailties and urges his people to plod further to where he tells them he envisages food. Their despair is increased when an oasis to which they hasten proves to be a mirage, but Odysseus reminds them that he had promised only a pitiless god of thirst, hunger, and war. Obscurely moved by the ruthless laws of survival and necessity, he determines to abandon all who do not have the strength to follow him, but der-hearted Centaur, enraged at his master's seeming inhumanity, refuses to leave the old and the children to their death, and stays behind to lead them.

Odysseus and his remaining troops plod on; he tells them fables to cheat their hunger, refuses to let them water even a flower for fear their hearts, also, might cast roots, and keeps them pitilessly on the march. (In Ithaca, meanwhile, Telemachus and Nausicaä play with their small son tenderly but are dismayed to note in him many characteristics of his fierce grandfather.) At length one day the troops sight a Negro village, but before they can decide how to proceed, they are attacked by a fierce Negro band which almost annihilates them. Centaur and his group, who had captured a Negro hunter and forced him to lead them to where food might be found, appear suddenly, and turn the tide to victory. They make peace with the Negroes and are welcomed by the village chieftain, a monster of fat, who mistakes Centaur for their leader because of his own monstrous bulk, and proposes to marry him to his daughter, "a hippopotamus of fat." A great feast is prepared in a courtyard under an oak tree hung with the skulls of enemies. Odysseus, suspecting that the Negro 
chief will try to surfeit them with food, drink, and women, warns his men to be on the alert. In an orgiastic dance and ritual, Centaur and his fat bride are wed, and all disappear to couple in the shadows, but as Odysseus keeps vigil and notices the Negroes stealthily gathering the weapons, he blows on his conch in warning, and with difficulty die entangles his friends from black erotic embraces. They plunder the village of food, leave behind those who refuse to continue, and plod on.

Centaur broods on the ruthless god of Odysseus who sieves out his followers so cruelly, according to survival, and plays no favorites. Odysseus tells his troops that all adventures and all experience led to further revelations of God, that God grows as man grows, changes with man's environment and culture, for it is man who feeds him: "God is the monstrous shadow of death-grappling man." God needs us, not out of love, but because we are the flesh through which he lives and grows. Granite declares he now knows for what two causes he' d given his life: for that which scorns man's comfortable virtues and restlessly seeks to find further horizons, and for that which declares that hunger and thirst are what impel men to explore and to seek. Odysseus agrees, and carries this thought still further: that salvation and destruction are one, for only by the dissolution of what has been accomplished can man enlarge his spirit and reach his only salvation. He tells Granite of his vision of a city based on this new vision of God and tells Centaur that cities must be created out of vision before they can be turned into deeds.

\section{BOOK XIII}

Through dark Africa to the source of the Nile. In his travels, meanwhile, Rocky stumbles on a seemingly deserted village at a time when the old king is being assassinated, according to traditional ritual, by three witch doctors to make way for a young fertile chief. The people hail as one sent them by their white-haired gods and make him chief. Odysseus and his of troops, meanwhile, have been pushing through a jungle of damp mold, of monstrous trees, entangling vines and savage animal here God has taken the mask of a frightening and fetid forest, of rapine and lust. Rocky is taught his duties as a chieftain of the Negroes and plans wars and conquests. One day Granite captures a female leopard cub and presents her to Odysseus; they become inseparable companions. Finally, the troops cut through the jungle and soon spy some Negroes tilling their fields, but these run away in fright at the approach of white men. Granite sights their village and wants to press on immediately, but Odysseus counsels waiting until the following day. At dawn three Negro envoys greet the white men as though they were gods, tell them of a plague which is devastating their village, and ask for help, but Odysseus speaks to them so fiercely in a demand for food as recompense, that the Negroes scatter in fright. The friends help Orpheus hew out a savage headless god from a block of wood, then Odysseus tells him to take this to the village, fall into a seeming trance, proclaim that this god will heal all ills, and then trade it for food; but he warns Orpheus that he must not be deceived by a few miracles that might indeed happen. Orpheus, however, is swept away by his own self-induced ecstasy and when, indeed, the crippled walk and the blind see, believes in the artifact of his own hands, falls down and worships the god he had created, and though he sends food to his friends, refuses to return, not even when Odysseus comes to take him. 
After a storm one day, Odysseus scornfully tells his friends what had befallen Orpheus. They spy a town in a deep gulch, and in a forest find some Negro boys undergoing a ritualist sexual spring rite before descending into the village to possess their brides. Leaving Centaur with the troops, Granite and Odysseus descend to the village and there with great joy are reunited with Rocky. Centaur joins them for a great feast. and a sorcerer conjures up a vision of Orpheus dressed as a witch doctor, prostate before his new god. After three days and nights of feasting, Odysseus bids Rocky cast off his new crown and join them once more, but when Rocky reminds him that, in _line with his own teaching, a pupil must cast off his teacher and become a leader of men in turn, to shoot beyond the twelve axes Odysseus once strung with his arrow, Odysseus rejoices, blesses Rocky, and asks for the blessing of the youth in return.

The friends leave Rocky, and after nine days of marching through stony wilderness, they sight some mountains and begin to climb them. One day Granite yells out, "The Sea!" and all, through a cleft, glimpse an endless blue-green shore. When they reach the waters, plunge into them with joy and find them sweet, they realize that they have come to the end of their journey, the lake source of the Nile where they plan to build their ideal city. Odysseus directs his troops to erect temporary shelters on the shore while he climbs the adjacent mountain to commune for seven days and nights with God in order that he may thus formulate the new laws and plans for the ideal city, accompanied by his leopard cub at dawn, he begins his ascent.

\section{BOOK XIV}

Odysseus communes with God. It is in this book that Kazantzakis develops the core of his ascetic philosophy, further amplified and more clearly systematized in his small book Spiritual Exercises: Salvatores Dei.

First Day (1-84). Odysseus climbs the mountain all day until at night he finds a cave in which to sleep where neither ghosts nor demons dare attack him.

Second Day (85-161). In the light of dawn, Odysseus sees that the walls of his cave are painted with primitive drawings of a hunt, and hails his blood brother, the first archer. He dedicates this day to song and joyful embracement of life, then daydreams of his most secret wish, the possibility of deathlessness, but a small worm climbs up his chest to remind him of his mortality. At night he sleeps once more in cave.

Third Day (162-443). Odysseus sits on a huge rock, calls the bird of to descend, then sinks into silent contemplation. He recalls his first experience with the three elements, woman, sea, and God: how as an infant he had almost fainted when he first smelled a woman's breasts, and how at the age of two he had pelted the sea with stones and yelled: "O God, make me a God!" He ate and became the things he ate, grew to adolescence, wedded, had a son, then went off to war. Choked with memories, he acknowledges that mysterious primitive forces within him have stifled much in his heart that cried out for liberation. He looks in the yellow eves of his leopard cub and sees himself as mankind's prototype, a caveman. Atavistic memories seethe within him, cruel hates and shameless longings in which his soul lies smothered; he becomes aware of man's fathomless line of evolutionary development from inanimate nature to all forms of animate nature, to man, to spirit. At sunset he sleeps on the rock and dreams that his heart and mind quarrel like an 
old married couple. The female heart is dissatisfied with the boundaries of law and Order which the timid mind is constantly erecting; she wishes to break through routine, cast off the yoke, smash down the middle wall of phenomena and plunge through into the other world, down into the abyss, into God; but the male mind scolds and tells her to be content with what is visible and at hand.

When the eternal Outcry in man shouts for help, the mind scurries away, but the heart pours out her blood in order that the phantom forefathers may drink and revive. An individual, however, must choose whom of his forefathers he wishes to revive, what of heritage and history he wants to retain. Odysseus thrusts away those who wish to live for material values only; he denies his father, Laertes, because a father must always give way to his son; he denies his family ancestors, for earth has now produced sons better then they; he denies even his dear friend Captain Clam because the world must be ruled not by love alone but by more ruthless principles of what is most needed. Only when his three great Fates approach does Odysseus give them of his blood to drink. Tantalus drinks, and then accuses Odysseus of planning to build a city and to settle down, of betraying the unappeasable heart, the restless search. Heracles drinks, and Odysseus hails him as that hero who in twelve labors pummeled man's flesh into a refinement of spirit, and weeps to see him now emaciated by death. Heracles urges Odysseus to complete the task he himself had left unfinished, to push on to the thirteenth and final labor (immortality), though he cannot discern what it may be.

Fourth Day (444-736). When he awakens, Odysseus becomes aware of all the phantoms he carries in his bloodstream. He knows now that he is the product of all these phantoms have clone and what they still long to do. He, like all men, is a bridge between past and future, holding within himself the dead, the living, the unborn. The realization that he carries infinite depths within himself frees Odysseus from a concern with his own Ego so that he knows now that he must go beyond the I to his own racial ancestors. But now he sees his third Fate, Prometheus, nailed to a rock, and addresses him as father of flame and brain, as the 'brave mind of godbattling man," as one who stabilized man on earth and yet impelled man's mind toward the sun. Prometheus laments that he has failed, forsaken and betrayed by man whom he had created, and that he could not finish "life's most glorious task," that he neither made his peace with God nor killed him, that "Beyond all flame and light, beyond even Death, my son,/the final labor, the last ax, still gleams with blood." He vanishes, and the Outcry is heard shouting for help once more.

Odysseus now plunges beyond his particular race and into a feeling of brotherhood for all races, realizing that he and all men are units in the evolutionary stream of all mankind. But now the voice of Mother Earth within him bids him push on beyond the boundaries of the human race itself to make his peace with all of nature, with beasts and trees, to direct her now and tell her what to do (as if, in the scale of evolution, man can now go beyond necessity and himself direct the life-process). In dreams that night, he feels himself a part of all animate and inanimate nature, of birds, beasts, insects, rocks and sea, until he touches the most atavistic and primordial sources of the universe, the inscrutable and uncompassionate rhythms where life and death cannot be differentiated one from the other.

Fifth Day (737-950). At dawn next day it seems to Odysseus that the men and beasts on the cave walls have come to life and swirl in dance about him. Soon he 
feels himself close-pressed by the phantoms of primordial life until they all make way for Leviathan, the most primeval ancestor of all, the great mass of somnolent life in which the soul had just begun to flutter its wings. After Leviathan passes, Odysseus opens his arms to welcome man's immediate ancestor, the Ape, and addresses him with homage and He turns then to all other creatures from which man is descended, even the humble dung-beetle and the ox. In his brain all become friends, the lion and the fawn. He welcomes the birds and the insects until his identification with living creatures is complete, so that in the spring rains that night all creatures seek shelter in his body and his brain.

Sixth Day (951-1246). Amid the rain-drenched earth at dawn, Odysseus listens to a male and female voice within his breast. The female heart, with love and tenderness, calls to the Spirit (to God), that is still submerged in mud roots and animal flesh, and longs to make it more human, to further it in its evolutionary ascent. The Spirit warns that it is savage and bloody, but when the heart still calls with love, it springs up as the heart would wish it, in form of a gallant youth. Odysseus now hears the Spirit (or God) groaning within himself, ever climbing a bloodstained road through inanimate and animate nature, and finally even through Trees and beasts smother God, even man's soul cannot contain his ever-upward reach, and he begs Odysseus to help him fight free. God is filled with fear, for he sees no end to the dark climb as he stumbles and struggles upward. Odysseus vows to dedicate himself to the liberation of this Spirit which in him cries out for help, and he now sees this vital impulse in all things, in the fruit he eats, in the seed he plants. All is one cyclical nourishment: "Birds, fruit, and water have all become Odysseus now!" He comes to the realization that it is God who is eternally crying out in man to be liberated.

The poet now addresses Odysseus to tell him that he has gone beyond the restrictions of his ego, his race, all mankind, and even all animate and inanimate things, until he has heard and understood the Outcry that stifles not only in all bodies but even in all souls and struggles to mount further still. This insistent struggle toward purer and purer refinement some call Love, some God, some Death, and some an Outcry. The soul now seems to Odysseus but a wick which the flaming Spirit consumes as it yearns for other kindling, that it might burn with a more rarefied light. He vows to build an ideal city that will embody his vision forever. Singing with joy, Odysseus suddenly sees a vision of God undergoing many forms: as Tantalus, as Heracles, as Prometheus, as charging armies that symbolize the military campaign of the spirit, and finally as an old vagabond, an outcast constantly scorned and persecuted, in whom may be seen "the savage bitterness, the spite, the unfathomed eyes,/the flickering flames that glittered in his eyes like snakes, /the bloodstained endless upward road he climbed with grief." Odysseus is wrung with compassion, and then filled with serenity as the setting sun and the full moon glow simultaneously on opposite sides of the horizon.

Seventh Day (1247-1410). An inner voice mocks Odysseus that his air-castles are of no worth unless realized in actual practice and works, in acts and deeds. With pebbles, clay and mud, he builds a model of his proposed new city, then plunges down the mountain slope. He knows that the world was made when two antithetical forces clashed, one male and the other female, in the arenas of phenomena and the mind. The Act hews forests, builds ships, and with its precious cargo, God, who is 
Wounded and bleeding, crosses the fearful abyss in a constant strife, age on hopeless age, "to raise the nonexistent shores from endless waves." A voice in Odysseus urges him to use all the powers of his mind and Imagination in order to shape nature and life in their image, for then man not only frees a god, but even makes a god. Odysseus embraces Lad Act as a bridegroom his fecund bride, then hurries to his fulfillment, e building of his ideal city.

\section{BOOK XV}

They build the ideal city. On his return Odysseus finds that his followers have split into two antagonistic camps led by Granite and Centaur. In disappointment and rage, feeling that man cannot ever attain those heights which their leaders envisage for them, he roams the forest for three days, and on the third day contemplates a wild pear tree that had split through a rock, into growth, and finally burst in bloom. It seems to him a gnarled symbol of the spirit's vitality, taking Whatever fate has given of soil and stone, and flowering stubbornly in the sun. Nearby, he finds an immense cave, then calls Granite and Centaur, makes his peace with them, and decides that, like the pear tree, he must accept given conditions and work with the recalcitrant herd of mankind.

Next dawn the foundations of the new city are laid. Six cocks and six hens are slain as symbols of the passing of the twelve Olympian gods. The people are separated into three groups of ascending rank: the craftsmen, the warriors, the intellectuals, and a socialist state is created (from various elements in Plato's Republic, St. Augustine's The City of God, and More's Utopia). Marriage is outlawed, children are to be held in common and educated away from their parents, old and useless persons are to be allowed to die. But Odysseus could not find the foundational law of his thought until one day he saw a flock of termites mating in the air. He saw that as soon as the bridegrooms had performed their one function, they fell expiring to earth, gobbled up immediately by birds, beetles, scorpions and snakes. With fierce joy, Odysseus embraces this as a ruthless law of necessity and survival in nature: "Whatever blind worm mother Earth does with no brains/we should accept as just with our whole mind, wide-eyed./lf you would rule the earth, model yourself on God!" Centaur is appalled by what he considers his master's heartlessness. Odysseus longs to tell his people of his new god, but he postpones doing so, fearing they are not prepared to accept so cruel, ruthless, and selective a god.

In the spring, after many months have passed, Odysseus declares a fiesta of three days for the mating of young men and women, and also sets his leopard cub free to find her own mate in the mountains. Again, he sees a vision of God as Commander in Chief, of all men as co-workers in the great battle where man must learn both to obey and to command. Each must act as though the entire salvation of the world depended on himself alone, but as though it did not matter whether he won or lost, for all that mattered was the struggle itself. One day he sees with horror a troop of blind black ants devour a baby camel, and then a human infant, and forever after keeps this vision before his mind's eye as the grinding destructive power behind all nature and human endeavor, the gaping gulp that awaits us all. He is overwhelmed by the tragic necessity of life. At last, one day he tells his people of the dread law of survival and existence, and that the new God they are to worship is not a protective and almighty god, but no weaker and no stronger than they themselves. 
Indeed, God needs their support, for not even he knows from whence he comes nor toward what he goes. All but Granite is dismayed by a god who cannot help them by supernatural means, who cannot be separated from themselves as struggling mortals. Centaur exclaims in despair, "Our bodies are the threshing floor where God fights Death."

Summer passes, and in autumn Odysseus declares the dying of a great chief as an occasion of joy, for this man had fulfilled his duty on earth; tragic would have been the passing of someone still young. (In Ithaca' his grandson dreams that his grandfather had given him a toy ship, and both Nausicaä and Telemachus are filled with fright.) When winter comes, all work at their various crafts in the huge cave. Odysseus carves the Ten Commandments of his god on stone, and each law revolves about the idea of God as a struggling evolutionary growth of the spirit throughout all phenomena. This tragic, necessary vision must be embraced with for "The greatest virtue on earth is not to become free/but to seek joy, freedom in a ruthless, sleepless strife." The last commandment is a symbol of the ascending struggle: "an upright arrow speeding toward the sun with pointed thirsty beak." When the time comes to inaugurate the town, there are many foreboding incidents. The air is hot and stifling, termites disintegrate Odysseus' hut and bow, rats flee down the mountain, screeching. As the people deck their houses and streets with palms, Odysseus looks with pride on his city where he believes the good life may finally be attained. An unnatural darkness falls, the moon becomes leprous, the earth shakes, and Odysseus, subconsciously aware of what is happening, rages against his betraying God. Rocky appears astride a white elephant, for he has sensed the danger from afar and has come to fight by his captain's side.

\section{BOOK XVI}

Odysseus becomes a renowned ascetic. Although ominous Omens pear, only Odysseus seems to heed them. All throng next dawn in the cave to celebrate the inauguration, but as Odysseus dances, the earth shakes and roars. Odysseus rushes out and sees the mountain belching smoke and lava. He rages against a god who made the world so imperfect that man is forced into an attempt to perfect it, then assigns various tasks to his friends and himself rushes to save the young children in the town. As the nursery begins to buckle, Centaur suddenly appears and props the doorway; Odysseus leaps free, but Centaur is crushed in the ruins. Soon the entire city, all but the North Gate from which Rocky had directed the fleeing troops, is swallowed in a gaping chasm.

Granite had begun to lead a troop northward, but returns and finds Odysseus, his hair turned white, clawing at a column of earth that soon reveals Rocky's cinderous body. It disintegrates, and in tragic fury Odysseus kicks the dust and bones into the chasm. Granite tries to comfort Odysseus, but "his mind marched beyond all sorrow, joy, or love, /desolate, lone, without a god and followed there/deep secret cries that passed beyond even hope or freedom." Granite leaves Odysseus forever and leads his group toward another life. Odysseus now falls into the "terror of thought," an inner contemplation Which blazes with light, and identifies himself with all of nature, the snakes and the grass, the ruthless laws of death and destruction, the seeds struggling toward light. He enters into a mystic communion 
with insects, fruits, and all growing things, with streams and stones. His feet flow like rivers, grass grows on his chest, morning-glories twine about his beard: "Odysseus brimmed with waters, trees, fruit, beasts, and snakes, /and all trees, waters, beasts and fruit brimmed with Odysseus." He comes to a tragic acceptance of life as it is, but transcends it with joy, and then blesses his five senses for their omnivorous and unslaked desire to know the entire universe, because Only through them may a man apprehend nature directly.

For many months he remains in ascetic contemplation on the rim of the abyss, and as his fame spreads throughout Africa, pilgrims come to worship him and to seek his healing powers. Telemachus appears to him in a vision and tells him not to push beyond man's possible attainments, but Odysseus calls to his first forefather, Tantalus, and cries: "Ah, grandsire, I've surpassed your pride; you thirst/because you've never drunken, hunger because you've never eaten, / but hunger itself has sated me and thirst unslaked me!" He identifies himself with all persons, with all human races in their brief lightning flash toward death. Pilgrims of every sort bring him gifts and hang them on the branches of the wild pear tree. A black chieftain gives him lumps of mud taken from his people's graves and kneaded with their tears, sweat, and blood, that the great ascetic might mold them a god to bear their pain, but Odysseus looks with compassion on man's futile efforts to escape suffering, and molds but maddening faces, monstrous forms of primitive terrors.

One day Temptation appears in the form of a snakelike Negro boy to mock Odysseus and to tell him that he has become decrepit, that his mind has disintegrated, that he is still filled with the pride and wrath of his ego. But Odysseus envisages a struggle of the mind that may push on even beyond man's physical limitations. A third inner eye of the life-stream itself now rises within him, and Odysseus blesses all his life as he recalls his daring youth, the sweetening influence of women on his character, how he longed to embrace his native land at first but then longed to travel .1 further. He blesses his restless search, his soul which has been faithful to no one thing: "My soul, your voyages have been your native land./With tears and smiles you've climbed and followed faithfully/ the world's most fruitful virtue-holy false unfaithfulness!"

Odysseus now turns to the playful creation of the mind, first with the lumps of mud given him by the Negro chief, and then with his flute. He sees a brief vision of his death amid icebound seas. He creates various fantasies of his mind - nymphs, the twelve months, werewolves, creatures of myth and legend, and finally an image of God as a vain, bearded, swaggering dwarf. When Odysseus turns to destroy him, God changes many protean forms and begs for his life, but Odysseus declares that even God is a creation of the mind, that like Orpheus he had almost believed in his own artifact. He destroys the image and rejoices in his freedom. Up to this point in his quest, Odysseus has tried to purify his concept of God, but now he turns away from even a monistic and anthropomorphic conception to a humanistic and evolutionary concept of nature, to representative types of men on earth for pattern, and extols man's mind as the Creator-for man himself, at least — of all phenomena. Death, not God, becomes his constant companion.

A voice now cries out thrice within him, and Odysseus recognizes Heracles, his great forefather who had struggled through twelve labors to purify his spirit through flame into light, who taught him to pass beyond all small passions, to aim at the 
great, and to strive still further, all in terms of actual deeds performed. Now, in death, Heracles sees that man may reach even further than the twelfth ax. He looks upon Odysseus as his heir, begs him to purify his mind of gods, demons, virtues, sorrows, joys, and the final and greatest foe, Hope, until there remains only the essence of flame, scornful and superhuman, a fire no thorns can feed. Odysseus realizes that he has now unbound himself from the final chain, that of Hope in an anthropomorphic God no matter how purified, and in complete freedom realizes that all phenomena, as an individual sees them, are the creations of each particular mind. The sun rises at his right temple and sets at his left, and "when/ the mind snuffs out like a thieves' lantern, all things vanish." With the aid of his senses, man weaves the fabric of his life over a bottomless abyss, over Nothing, over Death. Odysseus now exclaims: "No master-god exists, no virtue, no just law,/no punishment in Hades and no reward in Heaven." He has ascended the seven tiers of heads which he had bought from the peddler in Crete.

Frightened by his ecstasy and the blazing light of his freedom from God, the pilgrims had fled in terror. Now on the rim of the abyss, Odysseus dances ecstatically in affirmation of life with all its antinomies. He bites his heel and drinks his blood in a symbol of complete communion and acceptance. He has passed beyond arrogance and pride, the drunken rage of plundering and possession and guilt, until he who had striven to be the savior of the world finds that he is saved even from the need of salvation Stooping with humility and homage, he kisses Mother Earth and accepts the universe in all its aspects, both evil and good.

\section{BOOK XVII}

Divertissement: The drama of life. Odysseus remains in an ecstatic contemplation where past and future seem enveloped in an everlasting present. Life seemed, at times, the pursuit of women, beauty and pleasure; at times, the pursuit of virtue and justice; at times, the necessity of assisting an endangered God and embodying him in an ideal city. But now all these seem shadows, and Odysseus turns to embrace the nude body of life, stripped of all illusions; he bids her rise on the crags of strength and despair, on the peaks of both drunkenness and laughter, and there, according to the mind's playful desires, create whatever it wishes - a wedding pomp, a war, the normal life of a city. Odysseus smiles, and three maids are born. He calls, and an old man falls to the ground. He sighs, and a slim dancing girl springs up. He scowls, and battalions besiege a city. He contemplates gold, and a bazaar seethes with merchants and commerce. Odysseus is seized by an inexpressible love and compassion for these creations of his brain who rush through their roles as if they were real.

Slowly, as he comes out of his trance, his creations vanish until there remain only an old king, his son the prince, his faithful slave, a fierce warrior-king, and a maiden. Taking up a flute made of a dead man's bone, Odysseus plays till the characters come to life and live their roles; when he stops playing, they freeze in arrested postures. A drama unfolds among them, depicting the eternal passions of life: love, lust, jealousy, war, betrayal, the survival of the strongest. The maiden, daughter of a famous ascetic, lies in a forest beneath a tree where her father has just died. The king, in a gold chariot driven by his slave, searches throughout the forest for his son. The prince has found the maiden, declared his love for her, yet fears 
that she is not flesh, but spirit purely, Hearing the king approaching, and fearing that his father will part them, the prince urges the maiden to cast herself on the king's mercy, then hides himself in a cave. When the old "kina sees the maiden, he is terrified by her nakedness, senses evil and wants to withdraw, but because he has esteemed her father, he bids his slave clothe her and place her in the chariot. As the slave lifts the maiden, she admires his animal strength and wishes they were alone. Odysseus stops playing his flute and laughs to see life spinning its old rounds: the king cracking with desire; the temptress, which is woman, burning towns and castles in the offing. When a storm threatens, the old king stops by a roadside altar to pray, the maiden and the slave take shelter in a stable and fall to lust on a bed of manure and dung.

After the three reach the palace, the old king, tormented by jealousy and guilt, imprisons the maiden to keep her from the prince. Soon the warrior-king besieges the palace, the prince refuses to lead the army unless his father will free the maiden, but the king refuses and casts him in prison also. Then the slave prevails on the king to send the maiden to the warrior in order that she may seduce him and then behead him in his sleep. The maiden agrees on condition that the kina will give her his son on her successful return, and the king finally, in disgust and despair, agrees. Odysseus again stops his flute and urges the maiden to fulfill her role, one that scorns compassion, justice, goodness, truth, and has no care for virtues, ideas, men, or gods. Toward dawn, after the warrior and the maiden have passed a night of love together, he asks her why she had not beheaded him, as he suspected she would, and she replies that when he had laid his head, replete, against her bosom, she had felt a mother's compassion for her child. Now she urges him to fill her pouch with another's head that she may fool the old king and thus betray him into the warrior's hands. The old king thinks his kingdom has been saved, but his slave treacherously beheads him and presents the head and the keys of the city to the warrior-king, announcing at the same time that the prince has perished in the burning prison. The warrior-king declares that God is not concerned with love or compassion or friendship, that he cares for the strong only and supports those most fitted to survive who rule without compassion. He commands that the maiden be burned on a scented pyre with the honors of a great warrior.

Odysseus now stops playing, and the five actors sleep on. He addresses the Mind as the creator of all that lies fallow and shouts to be born, and to which the Mind gives form on the shores of insanity, which is life. There the Mind sits and plays the game of life, creates and destroys. Some have called the Mind Spirit and declared that it begat the flesh; some have called it Flesh and declared that it begat the Spirit; but it is something beyond both, and it plays in the abyss of the Universe. Man, with the free play of his mind, locks and unlocks the chambers of life, though he hopes for nothing; he does not complain under life's blows, but strides through the nonexistent palace of his desires as though it were real, holding the keys of Nothingness, for he knows that at bottom all is a dark abyss and an oblivion.

When day breaks, Odysseus continues his journey toward the southern tip of Africa. He sees that through his mind and senses now all the creative impulse flows and plunges, laughing, down the abyss: an image of a deathless flowing stream. Within him War (the ceaseless strife of evolutionary creativity) and Mind (that which gives the stream direction, order, body, shape) embrace in a creative strife. 


\section{BOOK XVIII}

The prince and the prostitute. Amid common scenes of daily life, Odysseus continues what he knows is his last journey and begins his last farewell to the world, rejoicing in life as though he were looking on all things for the first time. At noon, as a cricket perches on his right shoulder and bursts into song, Odysseus recalls how at Knossos a crow had perched on his shoulder, its beak still splattered with the blood of kings, and a profound spiritual change in him is thus symbolized, at night in a forest a black chieftain, slain in war, is burned on a pyre. Odysseus meets a hungry wolf but greets him like a brother. Himself weak with hunger, he welcomes death, and when he sees a peacock attack and devour a viper, another image of the grim struggle in life, of beauty fed by slaughter, he falls in a faint and dreams of pagan, bacchanalian Greece.

Next dawn as he continues his journey, he again falls fainting with hunger and is fed by a passing Negress bringing food to her husband in the fields. That night Temptation visits him again in the shape of a Negro boy and informs Odysseus that he now bears all the thirty-two signs of the perfect man, that he has therefore attained his salvation and should now scatter into non-existence, but Odysseus replies that the Tempter has not named the greatest sign of all: "I am the savior, and no salvation on earth exists." When the Tempter disappears, Odysseus regrets that he had not named for him a still greater sign: that embracing ecstasy (as in Yeats' Lapis Lazuli) which transcends all tragedy, for "Erect on freedom's highest summit, Laughter leaps."

On awakening next day, he sees approaching the elephant-caravan of Prince Motherth (the representative type of the Buddha). This Prince had once seen three fearful signs of man's decay - a diseased man, an Old man, a beautiful youth dead in his prime - and now roams the world in anguish, seeking to find the answers to evil, death, and decay. Hearing from a faithful slave of the great ascetic in Africa, the Prince had journeyed far to consult him, had pitched his camp close to his retreat, then sent three envoys to make their report. Each envoy returned with a different account of what he had seen: the first, an old man, had seen a baby; the second, a mature man, had seen War; and the third, a young man, had seen an ancient grandfather. When the Prince asked his slave to tell him what happens to a man's body when it dies, and the slave replied that it is eaten by six waves of worms, the Prince wept, unable to accept the horrors of death.

Odysseus suddenly appears, and Prince Motherth begs to be given some medicine that will prevent him from seeing the face of Death in all things. Odysseus re lies that both he and the Prince have looked beyond the gods and all lope into the face of Death, but that though the Prince sinks nerveless to the ground in terror, he holds Death before him like a black banner and marches on, for "Death is the salt that gives to life its tasty stim." Unable to accept Odysseus' heroic affirmation, the prince nevertheless accompanies the ascetic on his journey south, hoping to find a more palatable answer to his despair.

The ascetic's fame has spread throughout Africa, and all throng to watch him pass. Among these is the famous courtesan, Margaro, who invites Odysseus and Motherth to dine with her. Odysseus tells her that the secret paths to salvation are seven: the play of the mind, the fruitful drudging goodness of the heart, proud and 
lofty silence, fecund activity, manly despair, war, and love, and that she has taken the last and most occult, that which strives to merge antitheses as represented by male and female, that which breaks down the barriers of flesh in ecstasy until the lover shouts, "Ah, there's no you or 1, for Life and Death are One!" This is the very answer which the ascetic gives, and Odysseus calls Margaro his ascetic fellowtoiler," the martyr of joy, then asks her in turn for the distillation of all her experience. Margaro replies that she tells her lovers, "In all this wretched world, but you and I exist," and then, "Beloved, I feel at length that we two are but One." Odysseus replies that there is a third synthesis: "Even this One, O Margaro, even this One is empty air."

Motherth rejoices because he understands Odysseus to mean that not even Death has meaning, that it, too, is empty air, and decides to reject life in all its aspects and come to complete negation, to the via negativa. But Odysseus rejects both Motherth's nihilism and Margaro's affirmation of hope, and merges both views in a declaration that only by facing the hopeless and annihilating abyss of Death may a strong man then affirm life fully and raise the structure of his life on the rim of chaos, giving it himself meaning, beauty, worth, value, even though he knows that this is only an illusion: "Though life's an empty shade, I'll cram it full/of earth and air, of virtue, joy, and bitterness." Margaro cannot soar above the flesh, nor Motherth lift himself above the grave. Odysseus says that the truly free man not only plays with death as with one other element in the vital passing stream of the universe, but that he is even exhilarated by it; this proves too heady a wine even for Death himself, who vomits all he has swallowed. Margaro begins to see a glimmering of Odysseus' meaning, but Motherth, fully persuaded in negation now, abandons his kingdom, his wife, his newly born son, and wishes to free himself completely from all the trammels of flesh. But Odysseus again affirms the tragic joy in all of life, and as he says farewell to the prince and the prostitute and goes to cross the threshold, he stumbles, and Motherth burns his golden garments to light the ascetic's way.

\section{BOOK XIX}

The hermit's avid hand. As Odysseus is traveling through a forest, Death touches him on the shoulder and knocks him to the ground. "He had no god or master now: The four winds blew,/and in his chest his compass-heart led on toward Death." Within him a third, an inner eye, gazes on the world as for the first time, where no past, no present, and no future exist. He spies Death in the form of an old companion awaiting him under the shadow of a fig tree, but begs him to wait a bit more until they reach the sea, and when he continues his journey, Death follows at a proper distance as Odysseus bids the world farewell in a mystic trance where all opposites are joined in love. Again Death fells him, but Odysseus begs him to follow seven paces behind him until he can reach the edge of the continent and there build himself a skiff in a shape of a coffin, that he may return once more to the sea as to the womb. One day as he eats honey plundered by a bear to keep himself alive and to strive for freedom, he asks and replies: ('What freedom? To stare in the black eyes of the abyss/ with gallantry and joy as on one's native land." One day, Odysseus comes upon a blind hermit who asks him if he is the savior and ascetic renowned throughout Africa, but Odysseus replies that he is the savior of the world where no 
salvation exists. As in the woods about them the grim struggle for survival persists, the hermit confesses that all his life he has pursued answers to the eternal questions: "Why were we born and toward what goal?" yet has found nothing but a fearful abyss which he cannot interpret. He begs the ascetic for the final truth, but Odysseus replies that if he were to give the true answer and his answer were understood, it would crush the hermit's mind, and advises him only to press his ear against Mother Earth and to listen with care. By this Odysseus means that man must accept the earth's, or nature's, laws of necessitous strife, survival of the fittest, and ultimate annihilation, before he can hope to build bravely on the abyss. The hermit now regrets his abstemious life, his search for God, and wishes he might have lived like a mighty king replete with the joys of life, dispensing justice and goodness, asking no questions about life's purpose. As he falls asleep, he dreams of what he would have liked to have been.

He dreams of a great king replete with all the joys of peace and home who suddenly turns melancholy; nothing can give him pleasure, neither jesters nor women nor wise men. He hears a minstrel's song, but understands only that it is a lament, and crying out, "It's true!" casts away his crown and tries to escape from his kingdom, but finds that he cannot, for it is an island bounded everywhere by the roaring sea, by the abyss. Then a monster, the Law, attempts to constrain him within its confines, but the king's mind swallows the monster. God then tries to stop him, at the last limits of the world beyond which man cannot go, but behind God the king hears the sea still roaring, a further eternity, until God also sinks in the mind of man. Then the Mind itself rises and declares, "I only, man's great mind, exist on earth and sky," but even behind man's mind the annihilating sea roars and mocks, and the mind quakes. Reaching the sea at length, the king hews an image of himself as a tragic unlaughing man, sets it up as a sign, and speeds on his search, but one day, when he trips over his own image, he realizes that man is forever caught in the round trap of his own existence, his world, his mind, his given limitations. He strikes inland, climbs to the peak of a mountain of human skulls, and contemplates his long evolution from the sea and various forms of life to his present eminence as the Tragic Man. He cries out that the universe for each man is valid only in so far as a man is there to apprehend it, yet when he sniffs Death approaching, he suddenly stretches out a still-unsated hand and clutches his mother, Earth.

At this moment in his dream, the hermit cries out "Mother!" and dies with his hand stretched out, avid and unsatisfied. When the nearby villagers try to bury him, they find they cannot close the outstretched hand, and Odysseus tells them that it will not close until they have filled it with their dearest treasure. The elders cast their gold into the hand, the youths their weapons, the chieftains the bronze keys of the city, the mothers their tears, the maidens their kisses, a child its toys, but the hand still gapes, unsatisfied. Then Odysseus stoops and fills the avid hand with earth, and the hand closes, sated at last. Acceptance of Earth's necessitous law of annihilation is the bitter answer.

Odysseus continues his journey south and broods on the hermit's dilemma, knowing that some invisible force stamps us out the way a man's foot stamps out an ant heap. He travels amid scenes of massacre and destruction until he comes to a jostling village of oriental color and zest for living where even a passing girl will distract sons from their father's funeral. There he hears a minstrel singing about a 
Prince Elias whose father seemed as if he would never die or give up the crown. When a cock-pheasant sinos to Prince Elias in a human voice that only through song, the loftiest crown of all endeavor, may he hope to become glorious and immortal, the prince orders a lyre made with seven chords, but it remains silent whenever he strikes the strings. The cock-pheasant then informs Prince Elias that songs are paid for dearly, that each chord must be baptized in the blood of each of his seven sons. One by one Prince Elias takes his sons to battle, and one by one, as they are slain, he drenches each chord with their blood until the lyre bursts into ecstatic song. Cursed by his father, Prince Elias in turn curses all of life, flings his lyre across his back, and roams throughout the world. The minstrel declares that one day he saw Prince Elias sitting by a cliff's edge playing his lyre as the chords leapt "like man's sometime laughing sometime weeping heart." In this book Kazantzakis has contrasted the useless cyclical pursuit Of the hermit with the answer given to one who listens closely to the earth's annihilating response. A man is imprisoned in the kingdom of his earth and in his own identity; behind man's attempts to control phenomena by Law, by concepts of God, by the encompassing mind, the eternal sea of annihilation roars. With his works, nevertheless, with a song sung joyfully and gallantly above this abyss, a man may hope to keep his "deathless flame" burning a while longer. Thus, the tragic affirmation of life in joy is once more symbolized.

BOOK XX

The impractical idealist, the hedonist, and the primitive man. Captain Sole (the type of Don Quixote) takes up his rusted armor once more and sets out on his decrepit camel, Lightning, to save the world from slavery and injustice. Captured by cannibals, he is bound to a stake by their slaves and prepared for cooking, but Odysseus spies him and runs to his rescue. The cannibals, in fear of the renowned white ascetic, set Captain Sole free, but the black chieftain tells a fable to indicate that savage mankind can never be taught civilized ways, but will simply devour its idealistic saviors. Nevertheless, as soon as Captain Sole is freed, he dashes in frenzy once more to free the slaves, and though Odysseus admires this rash and rebellious heart, the imagination that dares to leap beyond the possible, he spurns it because it dwells far from reality, in wish-fulfillment and fancy only. Odysseus wishes Captain Sole well, and plods one Passing villager drugged with hashish, he broods: "Man's whole submission to all great necessities/alas, may be the only outlet Freedom has!"

Continuing his journey, he comes to great marshlands and an island with an ivywreathed tower set amidst turbid waters. He is taken to the Lord of the Tower, a fat and sluggish hedonist who has longed to converse with the famous ascetic, and has prepared him a gourmand's feast, but first entertains his guest with a cockfight. He marvels that Odysseus, unlike his other guests, gazes on the cruel battle with neither pleasure nor disgust, and Odysseus replies that his real eyes are indeed moved with joy and anguish at the death-struggle on earth, but that he also gazes on all things with an inner, a Third Eye, which remains serenely unmoved. The Lord of the Tower replies that best is the unconcerned mind which gleans its honey from every flower of experience but is never itself involved. Odysseus understands that this is a man who has never loved or hated, who mocks all spiritual values, the last dregs of a decadent and hedonistic existence. He then tells the Lord of the Tower that he 
had himself looked long on Death until he transformed all fear, joy and God into a spiritual flame, but the Lord misunderstands Odysseus to mean that life is without value, that the free mind keeps sterilely aloof. (The Lord of the Tower, Prince Motherth, and Odysseus have all confronted Death and the Abyss, but in different ways: the Lord with ironic and mocking indifference, concerned only to reap what passing pleasure he can; Motherth with negation and withdrawal; Odysseus with agony and the transforming joy which are both part of the onrushing creative drive.) Odysseus replies: "Both of us know the secret, but you in great exhaustion/play with both life and death with sluggish mocking heart;/l rush, clasp in my arms the smallest worm, and shout: / 'Dear brother, I'm your companion in both life and death!' " As Odysseus leaves, he recalls the bastard youths in Sparta who had fought with such vitality, and praises all striving, violent, evolving life.

In the woods one midnight, he watches the eleven sons of a black chieftain (who had previously killed one of his twelve sons) hunt down their old and sterile father in order to kill him according to traditional ritual, and then to possess his wives and kingdom. After they have slain him and each son has eaten in communion that portion of his father which contains the strength he covets, they resolve to fight among themselves until but one remains to possess both kingdom and wives. An ancient sorceress, however, proclaims the laws of a more civilized procedure: "Don't kill!" "Don't touch your father's wives," and bids them take their women from other tribes. As Odysseus watches, he feels that he, too, in distant ages long past, had evolved from such primitive origins and had once killed his own father. (The poet here deliberately contrasts the highly sophisticated and decadent Lord of the Tower with the ever-present atavistic primitivism in man.) Odysseus now hears Mother Earth crying for help to be freed from her primordial origins.

\section{BOOK XXI}

The gentle Negro fisher-lad. After several months, Odysseus sights the ocean, and as he hurries toward the shore, he passes a yellow and slanteyed race which he has never seen before, and a god with a huge emerald belly squatting cross-legged with half-closed sluggish eyes. When Odysseus reaches the shore, he plunges into the waves joyfully and plays with them for a long time, as with his faithful dog, Argus, then proceeds at night to the bustling harbor town and enters a tavern where sturdy sea captains are depicting their native lands. one, from the far South, tells of the snow lands; a red-skinned captain tells of a flame-drenched land of gardens and merchantmen; and Odysseus in turn tells them nostalgically of Greece. At this moment all rush to the door to watch a passing procession, and Odysseus is told that some shipwrecked Cretans, who have settled here, are celebrating their new god, whom some call Slayer, some Savior, but whom the priests in their secret rituals name Odysseus. In ironic mockery, Odysseus realizes that he has now been reduced to the stature of a god: "I've been reduced to a god and walk the earth like myth!/ O wretched soul of man, you can't stand free on earth [or walk upright unless you walk with fear or hope./Ah, when will comrade souls like mine come down to earth?" The symbols of the new god are fire, a bow, a full-rigged ship, the feather of a white peacock, and the Pole Star stuck on a white skull.

Next morning, after playing with the sea again, he walks through the town with a begging bowl, rejoiced to be brought to this state of essential simplicity, he who 
once had made love to the goddess Calypso and been offered immortal youth. As he stops to watch an old gardener forcing and training a dwarf pine into shape, he considers that just such a skillful, pitiless, erotic hand "fights with our hearts, and some men call it God, / some Fate and humbly bow, but I call it man's soul/ that now has freed itself and takes what shape it wills." As the young whores in the redlight district mock his aging body and his white hair, an old prostitute, Dame Goody, takes pity on him and gives him some pomegranates. He then knocks on the door of a newlywed couple, and when the young bride opens, tells her that there are three kinds of charities: the first and most modest gives only in terms of deeds done, the second identifies itself with the beggar until he is well fed, but the third and greatest feeds souls and gods till all merge into One, then abandons hearth and husband in a ruthless quest.

At dawn one day Odysseus fells some trees to build his last skiff. Rumors spread that he is assisted by spirits; the townspeople bring him food and votive gifts; and when a fisherman observes that his vessel resembles a coffin, Odysseus replies that he has measured his body, his heart, his mind, all earth, sky, fear, love, happiness and pain, and that this coffin-skiff is the result of all his measurements. His old crew comrades crowd round him now in the form of ghosts, but he refuses to take them with him on his last voyage, even in memory. Contemplation of an intricately wrought seashell evokes for him the slow evolutionary progress of the universe. In dream he shoots a roebuck with his arrow and then feels that he has pierced his own heart, but nevertheless he eats the meat with relish, for "A great and mighty tigress rules the living world." Although next day he fails to hunt down a stag in order to shape his last bow from its horns, he does find some stag-horns amid the votive gifts left by the townspeople, and with them shapes his bow.

One day amid some fishermen he hears a young Negro fisher-lad speak of One Eternal Father who is Love, of the earth as a path that leads into the sky. Another young fisherman opposes this as an unrealistic view of life, insisting that injustice rules the world, and that evil thrives. An old man replies that only with good deeds may one enter the Lord's gates, but the fisher-lad answers that man will enter heaven only by God's grace. When he says softly that if someone were to strike him on one cheek, he would turn the other, Odysseus hits him hard, confident that even this sickly boy will rise to defend himself, but when the lad does indeed turn his other cheek meekly, Odysseus shakes with terror at such a revolutionary view of the world. The two converse by the sea all night long, Odysseus upholding the path of war and strife, and the Negro lad (the type of Christ) upholding the path of love and peace, of selflessness, of an ultimate realm where man and God merge into One. Odysseus replies that even this One is empty air, but the lad insists that only this final One is real, "as the pure soul that broods on the world's sacred egg." Odysseus accuses the boy of loving only man's soul, whereas he loves man's flesh also, his stench, the earth, and even death, denying that the soul has value apart from the flesh, for it must evolve and purify itself in and through the flesh. When they part affectionately at dawn, Odysseus takes as his only weapons his bow, two flints, an ax, and whatever the townspeople had left him for food, then launches his skiff. Dame Goody runs up with a last gift of pomegranates. Leaping into his boat, Odysseus bids the earth a last farewell, tasting it slowly like a drop of dripping honey. 


\section{BOOK XXII}

Odysseus sails toward the South Pole. The poet invokes Virtue, most joyful when most persecuted, that struggles for the sake of the battle alone. As Odysseus sails and landmarks disappear, he recalls three tensions in his life: when he first held a woman's body, when he first grasped his son, when he had slain his first enemy. But now he faces the greatest of all: Death. He sees a shoal of sharks where the males contend bloodily for the female. A tumultuous rush of fish reminds him of the ecstatic flow of life, which he now blesses with all its wars, its cunning gods, its stupid men, its tears, and its laughter. When he passes by coral islands with huge wooden statues of primitive gods, with sunken cities in their shallow waters, he exclaims, "Dark demons, we have suffered much at your vast hands!" He now approaches the last antithetical limits of the world, the huge clashing mountains of Yes and No, but on coming close finds them to be serene peaks inhabited by flocks of birds. Climbing one of the peaks, he sees before him an endless sterile sea from which cold winds blow. After eating, he cuts into that virgin and cold sea.

The sun has been turning more and more pallid, hovering closer and closer to the horizon. He sees a whale swallowing a fleeing shoal of fish, recalls the black ants that ate the infant camel and the human child, and exclaims that there was a time when he named the lavish longing and fierce assault of life "God," but concludes that "God is a labyrinthine quest deep in our heads; /weak slaves think he's the isle of freedom and moor close, / all the incompetent cross their oars, then cross their hands, [laugh wearily and say, 'The Quest does not exist!'/But I know better in my heart and rig my sails: / God is wide waterways that branch throughout man's heart." The first ice floes drift by.

One day after sunset he sees the aurora borealis like a lustrous crown of death above his head, and that same night he crashes into an iceberg, is flung into the sea, and at sunrise climbs, exhausted, on a crag. As he plods over the snowfields and ice, he finds a hot geyser surrounded with shrubs and birds, eats and sleeps, then next day discerns on a boulder the fossilized marks of a primordial hot climate. After many days of plodding, he spies a human settlement of igloos, and is welcomed by the inhabitants as the Great Ancestor, the Great Spirit. He lives in the igloo of the witch doctor, shares their life, and discovers that here man asks not even for comfort or joy, but only not to be slain, for Fear and Hunger are the only gods. The pallid sun disappears, and through the long Antarctic night Odysseus watches many die of starvation as all wait for spring to ome and the ice to thaw; yet even here he blesses life.

When spring finally comes, all prepare joyously for their journey to eir summer sites, and as they speed in their sleds, singing, Odysseus bids them farewell and once more embarks, alone, in his new sealskin kayak. But suddenly the earth roars, the ground shakes, the ice gapes, and all - men, dogs, and sleighs - are plunged into an abyss of roaring, freezing waters. Once more the poet reminds us, and for the last time, of the yawning darkness which surrounds the universe and man's puny endeavors. As Odysseus watches in horror, he restrains his blasphemies, nor does he curse as when his city had also been swallowed by the abyss, but simply says: "O Sun, who gaze and shine on all this teeming world, /who without preference cast your rays on Life and Death/ nor pity man's misfortunes nor his rectitude, / would 
that I had your eyes to cast their light on earth, Ion sea, on sky, on wretched fate indifferently." He speaks to man's soul that sails on the dark waters of despair with Death at the helm, knowing there is no safe haven home, only the black cataract of death that whirls its ships onward. Odysseus worships the soul most when, knowing there is no salvation, it crosses its hands on the cliffs of despair, without hope or fear, and welcomes Death, singing.

\section{BOOK XXIII}

Odysseus blesses life and bids it farewell. The poet invokes the Sun, the source of heat and life. As the worm of Death arms itself to devour the archer, the sun laments that now it, too, will disappear, for it has existed only in the archer's mind. When the worm crawls on Odysseus' forehead, he shudders, and then sees a shadowy form on the prow of his boat which, after turning into many shapes, distills into the form of his old companion, Death, whose features are identical in every way with his own, for we each carry Death in our decaying bodies and nourish him as we grow. Odysseus welcomes Death as a long-expected guest. He recalls his past, tracing his life backward from old age even to the embryo and the rhythms of the universe. As he feels the five elements of his body disjoining, he summons Tantalus to tell him that he, too, has given up one security after another and now meets his end completely disburdened, until Death will find in him nothing to plunder but dregs. Vividly he recalls three images of his life: a rose on a cliff's edge shedding its petals into the abyss, the canaries that sang in the holocaust of Crete, a butterfly scorched in the sack of Knossos. He invokes and praises woman in his life, for only with love are the barriers of flesh demolished and the source of life penetrated.

He falls asleep and dreams of his ancestral dead and of his father, Laertes. All phenomena pour into his head to say farewell: the birds with sheathed claws, the tamed beasts, the stars and moon, great thoughts that strove to free men from fear and darkness, good and evil powers now reconciled. He awakes and rejoices to see his old friend still at the prow, but as Death suddenly vanishes, Odysseus knows that his end is drawing near, and he grasps his bow, his flints, and his ax that he may die armed. He recalls even his conception, and then his birth on a seashore when far-off visions of burning Troy and Knossos also rose concomitantly with his birth, and the twelve Olympian gods scattered in fear. Odysseus then blesses the five fundamental elements of his body: Earth, the ballast that keeps the ship on an even keel; Water, the restless, ever-flowing flux, the unsated voyager; Fire, that consumes all flesh and phenomena and turns them into spirit; Air, the final fruit of flame, the light, the drone that fructifies the queen bee, earth; Mind, the regulator and creator of all things, the charioteer of the other four elements which it drives headlong down the abyss with fearless joy. He dreams of God creating man to the terror of birds and beasts who sense that their master is being born, of man growing in pride and power until finally, in revolt and freedom, he chases God out of earth and into the sky.

As Odysseus sinks deep in the earth's roots, into Mother Silence, surrendering to the tide of non-existence, he hears an iceberg approaching, and as it looms before him, a mountain of ice, and crashes into his boat, he jumps up, flings himself on the slippery wall of ice, clings to it with bloody fingers, and tries to call to his old comrades for help, but the cry chokes in his throat. The ax slips from his waist, the 
bow falls from his shoulders, the flints drop from round his throat, the North Wind strips him bare, and all of nature bursts into lamentation. The seven lean crows who have followed him since his birth now huddle round his feet, and his seven souls come rowing on a cloud. His mind's final flame flickers on the wick of his backbone, and the worm takes its first bite as the five elements of his body snap and disjoin, and the sun prepares to drown. Only Love and Memory remain as they cast up their dead in a last effort. Odysseus' spirit, his consciousness, leaps like a flame from its wick, and for an eternal moment glows disembodied in the air before it vanishes forever: "As a low lantern's flame flicks in its final blaze/ then leaps above its shriveled wick and mounts aloft, / brimming with light, and soars toward death with dazzling joy,/so did his fierce soul leap before it vanished in air." It is in this eternal moment that the entire action of the twenty-fourth and final book takes place. The fire of memory blazes, clasps all souls it has loved on earth, and calls them to its assistance: "O faithful and beloved, O dead and living comrades, come!"

\section{BOOK XXIV}

The death of Odysseus. The four winds smash open the four gates of Odysseus' head. Through the north gate all plants rush into his head to strike deep roots; through the south gate animals, birds, and insects rush in to save their souls; through the east gate thoughts, dreams, and creations of the imagination rush pellmell; and through the west gate troop men of every race and kind. All mass in the streets and courtyards of the archer's spacious brain to live on in his memory.

But Odysseus cries out that he will not give up his soul before his dead companions come. Centaur hears his master call and leaps out of his grave, gathering his moldering bellies, and joins Orpheus, who has been weeping because he had betrayed his master. Together they rush through the air to join their dying friend. Captain Sole is lying on his deathbed when he hears the cry, and as he rushes along the beach to come to his friend's aid, he meets Hardihood, his head cloven in two. Captain Sole runs up to offer his assistance and put Hardihood's enemies to rout, but Hardihood only wonders with contempt where Odysseus had picked up such an evident fool. Dame Goody, her hands filled with pomegranates, hurries with Margaro who laments the passing of love and lust, but Dame Goody, to console her friend, recounts the seven types of men to Whom her body had given some consolation. She declares that she would take the same road in life again, but Margaro wants to tell the great ascetic that she has learned her lesson well, that though all in her arms had merged into One, that One was but empty air. Rocky hurries by on his white elephant, accompanied by the two Egyptian girls at whose home he had eaten, but when he meets Granite at the head of a great caravan laden with fruit and spices, he joins his friend with joy and leaves the two girls behind. Helen, her hair white with age, lies dying by a riverbank in Knossos, surrounded by her children and grandchildren, but when she hears Odysseus' call, she longs again to wreck her home, to take to sea, driven by fate. As she dies, she turns into a twelveyear-old girl on the banks of the Eurotas in Sparta, and as she rides a reed over the hermit's grave, he leaps out, rides his oaken staff with her, and longs for a home and hearth with just such a girl for wife. Diktena and Krino come riding the black bull which had killed the mountain maiden. Krino sighs and says that, could she only live her life once more, she would, like Diktena, enjoy the bodies of young men; 
but Diktena, in turn, longs to experience the pure joys of virginity. Captain Clam hurries by with Phida. He is anxious to join his captain on their last death bound voyage, and Phida laments that she can never wash her father's blood from her hands, that decadent Knossos had been destroyed in vain, for the slaves had once more turned abjectly to their slavery. Argus leaps out of his grave in Ithaca, joyous and proud because of all in his native island Odysseus has chosen neither his wife, nor his son, nor his father, nor his mother, but his dog only.

Under a tree in the Orient, Prince Motherth lies dying surrounded by his yellowrobed disciples, and when they ask for his final word, offers them only a faint smile. When they insist, he says that the roads toward salvation are five: through love, despair, beauty, play, and truth, but that beyond all these, beyond the Word, lies only a wordless smile. As he prepares again to die, two men arrive from Greece, for they have heard of the great Oriental sage and have come to reap his wisdom. They debate with his disciples on the relative merits of the East and the West, the Orientals insisting that all is illusion and dream, the Greeks upholding the anthropomorphic conception of gods, denying the abyss, and placing emphasis on virtuous deeds, on the Apollonian view of harmony and balance. The older man addresses Motherth directly and speaks of philosophy, of how order must rule anarchic rage, of how the Word and not the Smile must reign supreme, but when Motherth simply smiles in answer, the younger man rushes to embrace what now seems to him more lustrous than the mind, and proclaims Motherth to be a greater Dionysus. But Motherth is sinking into death, Odysseus' cry for help tears the sky, and an eagle swoops down and carries off the great sage in its claws.

Rala hurries to fall into the arms of the man she loves, regretting that she had ever espoused an abstract cause or denied herself husband and children, scornful that she is now worshiped on earth as a virgin martyr. She is joined by the Negro fisher-lad who had preached of love and peace, but Rala rages against him in contempt, finding his philosophy pallid, cowardly, chaste, and of a cloying sweetness. When the leopard cub leaps out of some bushes, Rala welcomes her as a twin sister.

Thus, all those whom Odysseus has kept alive with love in his memory rush to help their master in his last moment. Rala and Phida embrace as friends, Krino falls into Helen's arms, Margaro and Diktena join hands. Odysseus spies them from afar, welcomes them to his white ship of death, and begs them to hang the masts with the figs and grapes he has loved so much. He sees Captain Elias' blood-soaked lyre and longs to "pluck its chords/and play Life's great refrains to keep Death entertained." All rush and crowd the icy ship of death, Rocky on his elephant, Krino with her black bull, while Aygus licks his master's feet. Now the three great forefathers come, the three Fates - Tantalus, Heracles, Prometheus - and plant themselves on the deck like three towering masts from which the women hang pomegranates, figs, and grapes, until the death-ship glows like a garden. The cricket that had once perched on Odysseus' shoulder comes again, hides in his beard, and bursts into rasping song. Then finally Temptation, that small Negro boy, crouches at Odysseus' feet, and as the two look laughingly into each other's eyes, they play with all of life until the universe merges into a forked flame and the mind soars like fire and longs to burn all away into nothingness once more. As the Negro boy falls asleep, Odysseus fondles him, and when the boy awakes and looks up again, he shudders to see the whole world swirling in dance within the world-destroyer's eyes. When 
the boy falls asleep again, Odysseus hangs him like a scarecrow on one of the masts. Now that the time has come for final farewell, Odysseus laughs, thrusts his hands into the pomegranates, figs, and grapes, and all suddenly vanish. Then his mind leaps, soars, and frees itself from its last cage, that of its freedom.

\section{EPILOGUE}

The poet invokes the sun who in great sorrow has sunk beneath the horizon but refuses the food and drink prepared him by his mother. He upsets the tables, pours the wine into the sea, and laments that his beloved one has vanished like a dwindling thought. Thus, the poem begins and ends with the sun, itself a long metaphor of the transmutation of all matter into flame, into light, into spirit. 


\section{Anexo 3}

Consta aqui o resumo escrito pelo Professor chileno Miguel Castillo Didier de quem me aproximei em 2010, inclusive visitando-o em Santiago do Chile. Desde então se estabeleceu um intenso diálogo entre nós e uma extensa e valorosa colaboração do Professor com o meu percurso de captação de material e fontes. Assim me foi disponibilizado por parte dele todo tipo de consulta de que precisei e, no segundo semestre de 2020, participei de um curso online com duração de 60 horas aula sobre Nikos Kazantzákis que me forneceu maiores insumos para a presente pesquisa. Didier possui uma vasta obra de pesquisa dedicada à obra de Kazantzákis e é uma referência nos estudos deste autor. A quase totalidade das fontes pesquisadas se encontava escrita em espanhol língua com a qual eu tenho mais domínio, e portanto será também disponibilizada.

\section{Síntesis}

\section{Rapsodia I -Desencanto y sublevación}

Después de colgar el arco, tinto en la sangre de los pretendientes, reposa Odiseo, tomando un baño tibio, y se dirige a ver a su esposa. El encuentro es frío. La acogida del hijo es casi hostil. Estalla enseguida una sublevación encabezada por las viudas de los caídos en Troya y por los inválidos de la guerra. Odiseo logra dominarla con su astucia.

Durante el festín que Ulises ofrece al pueblo luego de dominar la insurrección, el cantor rememora el nacimiento del héroe y recuerda a los tres semidioses que, reemplazando a las Moiras, patrocinaron su destino. Fueron Tántalo, quien le dio la insaciabilidad de su pecho; Prometeo, quien le otorgó la relampagueante claridad de su mente; y Heracles, quien lo bañó en la luz perenne del espíritu.

El recuerdo de los elevados signos que presidieron su venida al mundo exalta en el héroe los anhelos de liberarse del ambiente cada vez más estrecho y aplastante de su isla. Cuando da libre expresión a su estado de ánimo, la fiesta termina bruscamente, ante el asombro popular por la repentina furia del rey.

Odiseo se dirige a una playa desierta para tranquilizar su espíritu. La idea de la nueva partida trae paz a su alma y se duerme entre los peñascos junto al mar.

\section{Rapsodia II -La partida}

Odiseo relata sus hazañas y sus padecimientos a Penélope, Telémaco y Laertes. Cuanta cómo se libró de los lazos de perdición que Zeus le envió como castigo de su soberbia, a través de Calipso, Circe y Nausícaa. Mientras relata sus batallas ganadas, reflexiona pensando que después de aquellas no le será posible permanecer en la isla, atado por la "decrépida virtud", junto al "honrado hogar".

Elige cinco amigos para partir: Stridás, viejo lobo de mar; Karterós, un rubio bárbaro que se desempeña como herrero del palacio; Centauro, un fiel compañero, 
amigo del buen vivir; Suralis, un inspirado músico; y Rocal, un fugitivo que llega a la isla.

Antes de iniciar el viaje, Ulises entierra a su padre, que ha muerto, y casa a Telémaco con Nausícaa, cumpliendo el compromiso contraído con ella cuando dejo el reino de los feacios.

Una noche preparan las provisiones y las cargan y parten al alba.

\section{Rapsodia III -Odiseo en Esparta}

Han zarpado desde Itaca sin tener decidido un destino. Mientras ellos navegan, allá en Esparta Helena siente que el tedio la abruma. El viento lleva la tristeza de la hermosa mujer hacia la barca de Odiseo. Éste decide dirigirse a la ciudad de Menelao.

Desembarca y en el viaje hacia Esparta divisan por primera vez a bárbaros rubios que descienden desde el norte. Una civilización está terminando y está naciendo otra. La violencia y la guerra conmueven a las ciudades griegas.

En Esparta, el pueblo hambriento amenaza la autoridad real. Entre las dos fuerzas en lucha, Ulises se decide por el partido del rey y con su ingenio desbarata la sublevación.

\section{Rapsodia IV -EI "rapto" de Helena}

Menelao festeja a su huésped y le muestra sus posesiones. En un aprisco del ganado, el visitante hace otro amigo: Pétrakas, el cabrerizo, quien se integrará al grupo que viaja con Ulises

Después de un banquete, Menelao regala a Odiseo una estatuilla de oro de Zeus Hospitalario.

Desafiando al dios, el huésped se marcha con Helena secretamente, al amanecer. Ella estaba deseando dejar un ambiente tedioso que la oprimía y salir a la aventura.

\section{Rapsodia V -Odiseo en Creta}

Una tormenta arroja a los navegantes a Creta. Al desembarcar en la isla, Ulises vende la estatua de Zeus.

En Creta la civilización también vacila. Idomeneo, el senil monarca, ha ascendido al Monte Sagrado y ha penetrado en la Gruta del Dios-Toro, a fin de cobrar nuevo vigor. Al bajar a Knosos, deberá unirse a una Mujer-Becerra durante una orgía taúrica en el palacio. De ese modo, la fuerza que la divinidad le haya conferido se transmitirá al pueblo.

Odiseo decide que Helena sea la Becerra y esto le servirá a él para la realización de sus propósitos destructivos del régimen imperante, que incuba en su mente.

\section{Rapsodia VI -La orgía táurica}

Nobles y pueblo toman parte en la orgía taúrica. Después de un juego dramático, un toro da muerte a Krino, hija virgen del rey. Dijtena, su hermana, se une a Ulises en fogoso amor. 
Una tercera hija del rey, aprovecha el desenfreno de la ceremonia para preparar una sublevación de esclavos. Un bárbaro rubio conspira junto a Fida. Otro enamora a Helena.

Odiseo se une a la rebelión. La orden divina es destruir el régimen injusto y decadente.

\section{Rapsodia VII -La conspiración}

Odiseo ha decidido destruir el palacio de Knosos. La divinidad ya no puede habitar entre el rey decadente y tiránico y los muelles nobles. La nueva civilización ha de nacer del pueblo y de los rubios bárbaros del norte.

El Destructor-de-Fortalezas distribuye los trabajos para el levantamiento y participa de sus proyectos a Helena y a Fida.

Pasa el invierno y el palacio es adornado para la fiesta de la estación primavera. Durante ella debe estallar la revolución.

\section{Rapsodia VIII -Destrucción del palacio de Knossos}

Mientras el rey y los nobles celebran la fiesta en los patios del palacio, los sublevados apagan las luces y le prenden fuego. Idomeneo es asesinado.

La destrucción de la fortaleza coincide con la llegada de los rubios bárbaros del norte, que llegan por el mar en múltiples barcos.

Odiseo entierra a Stridás y a Fida, que han caído en la lucha. Deja en el trono de Creta a Karterós y se despide de Helena, cuyo vientre ha sido fecundado por un bárbaro.

Con los cuatro amigos que le restan, Odiseo se hace a la mar, rumbo a Egipto, llevando consigo a la princesa Dijtena, a quien abandona después en una playa. El navegante intentará remontar el gran río Nilo hasta alcanzar sus desconocidas fuentes

\section{Rapsodia IX -Odiseo en Egipto}

Al desembarca en Egipto, los peregrinos se enteran por el canto de un ciego de la general situación de miseria de los trabajadores. Remontando el Nilo llegan a Heliópolis. Saquean una tumba y después, durante la navegación que sigue, Odiseo dispone arrojar al agua todo el botín que llevan, para que sus espíritus no sean confundidos con las riquezas.

Mientras reman, Suralis trae en su canto el recuerdo de Helena. Allá, en Creta, ha dado a luz un hijo del bárbaro, símbolo de la unión de dos civilizaciones.

Hasta ahora, la Belleza ha deslumbrado al viajero (Helena). Ahora lo guiará el Hambre, a la que bendice como diosa.

Los navegantes arriban a la capital faraónica, azotada por el hambre. Ulises deja allí a sus compañeros y se adentra solo en el país.

\section{Rapsodia X -Revolución en Egipto}

Egipto está siendo estremecido por una revolución. El hambre y la hebrea Rala guían a las multitudes. Junto a la joven, están el artesano Gérakas, el aldeano Escarabajo y el revolucionario Nilos (Lenin), figura noble y atrayente. 
Una voz interior ordena al héroe participar en la lucha, junto a los sublevados, $y$, aunque no del todo convencido, se une a ellos. Es encarcelado, junto con Rala. Liberado, parte de nuevo con sus amigos, guiando su barca Nilo arriba.

\section{Rapsodia XI -La revolución derrotada. EI nuevo dios.}

Los bárbaros rubios han invadido también a Egipto y el país vacila bajo su empuje. Odiseo, interpretando la voluntad de la divinidad, se alista junto a los invasores, que coinciden con los pobres egipcios. Rala muere atropellada por una multitud de jinetes bárbaros. Odiseo es apresado de nuevo junto con sus amigos. En la prisión, esculpe en un tronco la imagen nueva del dios. Cuando el faraón lo hace comparecer a su presencia, lleva la imagen y baila una terrible danza. El rey, empavorecido, le da licencia para que parta con quienes desee.

Ulises se siente renacer y decide realizar su anhelo de seguir navegando hacia el sur y construir una ciudad perfecta, sin injusticia ni maldad. Se despide de sus amigos revolucionarios.

\section{Rapsodia XII -Marcha en el desierto}

Odiseo decide llevar consigo sólo a quienes han pisoteado los grandes mandamientos. Levanta en un escudo la imagen de su dios, por él forjado. A sus seguidores les parece que una ciudad resplandece en la mente del héroe: todos la habrán de construir. Durante la travesía por el desierto, el hambre y la sed azotan a los peregrinos. Luchan Finalmente, el rey nativo hace a Centauro su yerno por una noche y ofrece un festín durante el cual proyecta atacar a los caminantes. Odiseo se da cuenta de sus designios y reúne a sus hombres. Parte con los que acuden al sonido de su corno. De noche, junto a una fogata, describe su dios al pueblo. A todos los sobrecoge un entusiasmo sobrehumano.

\section{Rapsodia XIII- Rapsodia de Pétrakas}

Pétrakas se salvó de unos antropófagos, bailando para ellos una danza que los hechizó. Después tomó una senda que lo condujo a una aldea principal, donde el pueblo negro lo proclamó rey, pues acaban de dar muerte al rey que había llegado a la vejez.

Por su parte, Odiseo y sus hombres, después de atravesar un desierto y una selva, encuentran también una aldea. Ulises envía a Suralis a vender un dios a los negros y a proveerse de alimentos. Un cachorro de leopardo que Rocal le regala a Odiseo entretiene a éste con sus juegos. Siguiendo el camino, llegan al reino de Pétrakas. Odiseo va a saludarlo a su palacio y lo insta a seguir viaje juntos. Pero aquél prefiere seguir su vida entre los negros.

Los viajeros prosiguen la travesía y llegan a las inexploradas fuentes del Nilo. Ulises se retira durante siete días a una montaña para meditar sobre la ciudad que proyecta construir.

\section{Rapsodia XIV - Ascética}

Odiseo asciende hasta la cumbre de un monte para su "ascesis", acompañado sólo de su pequeña leopardesa. En cada tramo de su subida, su espíritu se eleva del Yo 
a la Raza, de ésta a la Humanidad y finalmente de la humanidad a la Tierra. Llega a mirar a dios como una llama que impregna el universo.

Ya está preparado construir la fortaleza donde custodiará a la Llama. Pero una sierpe, la Tentación, se alza y se burla de él, porque no ha entrado todavía a la esfera de la Acción. La Ciudad de construirá con piedra y madera, no con pensamientos. Con lodo y guijarros, Ulises plasma una primera imagen de su proyecto.

\section{Rapsodia XV - Construcción de la ciudad: utopía}

Al bajar de la montaña, Odiseo comprueba que Centauro y Rocal han reñido y han dividido al pueblo en dos facciones. Une a sus dos amigos y echa los cimientos de la Ciudad: degüella seis gallos y seis gallina- los doce dioses olímpicos - y los entierra allí para siempre.

Se va construyendo la Fortaleza. Cada tarde, después del trabajo, Ulises inicia a los hombres en la idea de su dios y sus mandamientos, en los principios de la Ascesis. Cuando la Ciudad está terminada, extraños signos presagian una desgracia. Llega Pétrakas, que ha abandonado su reino y ha acudido a ver a Odiseo en momentos que el siente peligrosos.

\section{Rapsodia XVI - Destrucción de la Ciudad}

El volcán, en cuya falda se alza la Ciudad, descarga fuego y piedras sobre ella, mientras la tierra tiembla violentamente. Muere Centauro por salvar a Odiseo. Al día siguiente, encuentran también muerto a Pétrakas.

Ulises ordena a Rocal que conduzca a otro lugar a la gente que se haya salvado, y él se marcha solo a una segunda ascesis. Ésta lo transforma de tal modo que una multitud de veneradores acuden atraídos por su aspecto de santo. Per el rudo Odiseo los desencanta con sus palabras: "No existe ni virtud ni justicia". El Destructor-dedioses ha llegado a su liberación espiritual.

\section{Rapsodia XVII - La plena libertad}

La ascesis ha conducido a Odiseo a la perfecta libertad: todas las cosas son sueño que la mente engendra por un instante. Sopla luego levemente y el mundo se purifica. Ahora Odiseo puede "jugar". Su mente plasma toda clase de criaturas. Conserva a cinco de ellas y las confunde en un diálogo dramático, que está más allá del bien y del mal. Sus criaturas quisieran sobrevivir, pero su creador sopla y las criaturas desaparecen.

Odiseo saluda a su espíritu, "el gran maestro de ceremonias", que lo ha liberado de inconfesables anhelos y se alivia con los juegos del arte.

Un día nuevo amanece, Liberado, salvado, purificado, emprende el descenso para proseguir su camino en soledad.

\section{Rapsodia XVIII - Rapsodia del príncipe y la prostituta}

El Varón-de-muchos-rostros prosigue su peregrinar hacia el sur. Caronte se presenta ante él en la forma de una gran mosca. Lo rechaza. Repentinamente ve en sueños a la lejana Grecia. La Tentación se presenta otra vez, pero el peregrino la aparta. 
Un amanecer se cruza con una caravana. Levan allí al príncipe Manayís, Madretierra, quien desea escuchar palabras de salvación de labios de un gran asceta, cuya fama cunde por África. El príncipe vive atormentado de continuo por el pensamiento de la muerte. Discute con el Asceta. Éste no renuncia a la vida por el hecho de tener que morir. Es justamente la muerta la que da valor a la vida.

Entran a una ciudad, donde Perla, famosa prostituta que de los siete caminos de salvación ha elegido el amor, los recibe y les brinda hospitalidad en sus jardines. La cosmovisión del Asceta se mide con la de Manayís. Perla es atraída por las palabras de aquél. Aunque la vida sea una sombra, ella le ha de gozar hasta que sus ojos se cierren.

Ulises se despide el príncipe y de la prostituta. Aquél abandona sus vestidos y joyas de monarca y se hace asceta.

\section{Rapsodia XIX - Rapsodia del Eremita y el Capitán Elías}

Entre las cejas de Odiseo aparece el signo del "ojo del conocimiento". Se hace presente Caronte y el peregrino le ruega que le dé más tiempo para llegar al mar y construir su último navío. Esta vez Caronte toma la forma de un anciano que espera a Odiseo a la sombra de una higuera.

Más adelante, el viajero encuentra a un Eremita, a quien una vida de virtud y ascetismo no ha calmado, y que espera también una palabra de salvación. Conversan Odiseo y el anciano y éste muere después de un terrible sueño, quedando con su nao extendida. No la aprieta sino cuando Ulises la llena con un puñado de tierra.

Continuando su camino, el peregrino llega a una poblada ciudad. Allí, un músico negro canta la historia del Capitán Elías, que eligió el canto como su corona. Mas para que su lira resonara, fue necesario empaparla con la sangre de sus siete hijos. El padre de Elías maldice a su hijo. Éste maldice todas las cosas y parte a peregrinar por la tierra con su lira. El músico que canta esta historia dice que vio a Elías cantar al borde de un abismo y oyó resonar las cuerdas de su lira como entrañas humanas que ríen y sollozan.

\section{Rapsodia XX -Rapsodia de Don Quijote}

Más al sur, Odiseo encuentra al Capitán Uno, quien ha salido a deshacer las injusticias del mundo, cabalgado en un viejo camello. Por salvar a unos esclavos, cae en manos de una tribu antropófaga. Odiseo lo salva de la hoguera y saluda en su persona una locura semejante a la que él posee. El Capitán Uno persiste en su acción justicia y se separan los caminos de él y de Ulises.

A poco andar, Odiseo llega hasta la torre de un noble señor, Hedonista, , quien vive libando todas las cosas placenteras, sin que su alma se encadene a nada. Tal es la norma del noble gozador.

Después de dejar al noble Hedonista, el peregrino penetra en una espesa selva, donde lo ruba una pesadilla. Ve a varios jóvenes, Hombres Primitivos, que matan y devoran a su anaciano padre para tratar de quitarle sus mujeres.

\section{Rapsodia XXI -Rapsodia de Jesús}

El Arquero-del-Espíritu arriba por fin al mar, a un poblado donde habita un pueblo de marinos. En una taberna oye hablar por primera vez de una aurora polar y desea 
morir bajo aquella luminosidad del cielo. Pasa una procesión frente a la taberna: los nativos veneran un nuevo dios que le trajeron marinos cretenses: jes el mismo Odiseo que atravesó como un fuego divino por la isla de los minoicos.

El hambre atormenta a Ulises: tiene que mendigar. La vieja prostituta Kalí, Buena, le regala dos granadas.

Es otoño. Comienza a construir su barca. Un día, unos pescadores dejan las redes y sea van tras un joven negro que les habla de un Padre que habita en los cielos y les enseña el amor y la paciencia. El Asceta se le acerca y expone sus ideas medirlas con el mensaje del joven. Las palabras del pescador y sus enseñanzas conmueven a Odiseo. Pero debe seguir su camino, ahora por el mar.

Poco después echa su barca al agua. Cuando va a partir, la vieja Kal le trae todas las granadas de su jardín.

\section{Rapsodia XXII -La aldea polar}

Odiseo navega hacia el sur. Su soledad es absoluta: "grande y libre alegría". A medida que avanza, el día va disminuyendo. Las corrientes se acrecientan. Aurora polar. La barca se rompe en unos peñascos. El navegante se interna en tierra firme y llega a un pueblo que resplandece en medio de la noche. Pasa el invierno con ellos y ve que los aldeanos sienten hambre, frío y un miedo cósmico. "Nonos des muerte, oh dios, es la plegaria que todos repiten aterrados.

Cuando el tiempo mejora, el Siempre-Errante-Varón echa al mar una nueva embarcación, hecha con cuero de foca. Los aldeanos parten alegres en sus trineos hacia un lugar más cálido donde pasarán el verano. Desde su barca, Odiseo los divisa alejarse en hileras de trineos. De repente, se parte la meseta helada en dos y la grieta devora los carruajes y todos sus ocupantes. El dios les dio finalmente la muerte, pese a sus ruegos. El peregrino conoce ya esa realidad: el hombre navega por las aguas de lo inesperado, llevando como piloto a la Muerte.

\section{Rapsodia XXIII -La última navegación}

El poeta ruega al Sol que acoja en sus brazos a Odiseo. El Sol se lamenta por la desgracia que llega. Odiseo consuela al Sol.

Caronte, con un aspecto idéntico a Odiseo, se sienta en la prora, frente al navegante. Los recuerdos estallan en el espíritu de éste: barcos, mares, tempestades, ciudades que se construyen y caen despedazadas. Un sueño ilumina su alma: aves, animales, astros, grandes pensamientos, espíritus, vienen en oleadas a despedirse. Caronte desaparece de la proa.

Odiseo cruza sus brazos y deja que lo arrastre la corriente. Hasta entonces, su cuerpo sintetizó los elementos que ahora se disgregarán. Se despide y bendice a la tierra, el água, el fuego, el aire y el espíritu, el Gran Maestro Primero que reúne esos elementos.

Una montaña de hielo se atraviesa frente a la barca: "Este es el albo elefante que me conducirá al Hades", exclama. Se lanza al água. Trepa al epñasco de hielo, desarmado, desnudo. Mientras el mar se conduele, el Gran Asceta lanza una última llamada a sus fieles compañeros, muertos y vivos.

\section{Rapsodia XXIV -Desmaterialización}


Todos escuchan la llamada de Odiseo. Sus antiguos amigos Suralis, Rocal, Pétrakas que viene cabalgando en un elefante blanco, Karterós, Centauro y Stridás (que han muerto); la anciana Kalí, Perla; Lirio, que cabalga en el toro que le dio muerte; Dijtena, la princesa abandonada; Fida, la princesa revolucionaria; Helena, ya anciana de blancos, viene en forma de una niña de doce años; el príncipe Manayís (agoniza en un monasterio, rodeado de discípulos y un águila lo coge en sus garras y lo lleva por los aires); el viejo Eremita, que había perdido su vida; Rala, que sigue la ruta señalada por el águila que lleva a Manayís; la sombra del joven pescador negro; los tres ascendientes Tántalo, Prometeo y Heracles: llegan flores, frutas, animales; a entibiarle los pies llega el perro Argos que sale de su tumba en Itaca; finalmente llega hasta la Tentación.

La montaña de hielo se pone en movimiento. El espíritu de Odiseo se libera de su última prisión: su libertad. Y se desvanece en el éter.

Terminada la última rapsodia, el poeta se dirige al Sol, quien he llegado donde su madre, muy dolido, porque ha visto desvanecerse a su amado "como un pensamiento". 